DIOGO DE SOUZA DUTRA

\title{
AN INTENTION-BASED SERVICE DESIGN DISCIPLINE FOR THE PRODUCT-SERVICE ARCHITECTURE
}

Dissertação apresentada à Escola Politécnica da Universidade de São Paulo para obtenção do Título de Mestre em Ciências. Área de Concentração: Engenharia de Controle e Automação Mecânica. 
DIOGO DE SOUZA DUTRA

\section{AN INTENTION-BASED SERVICE DESIGN DISCIPLINE FOR THE PRODUCT-SERVICE ARCHITECTURE}

Dissertação apresentada à Escola Politécnica da Universidade de São Paulo para obtenção do Título de Mestre em Ciências. Área de Concentração: Engenharia de Controle e Automação Mecânica.

Área de Concentração:

Engenharia de Controle e Automação Mecânica

Orientador:

Prof. Dr. José Reinaldo Silva 
Este exemplar foi revisado e alterado em relação à versão original, sob responsabilidade única do autor e com a anuência de seu orientador.

São Paulo, February 20, 2017.

Assinatura do autor

Assinatura do orientador

\section{Catalogação-na-publicação}

Dutra, Diogo

An Intention-Based Service Design Discipline for the ProductService Architecture/ D. Dutra. - versão corr. - São Paulo, 2017. $147 \mathrm{p}$.

Dissertação (Mestrado) - Escola Politécnica da Universidade de São Paulo. Departamento de Engenharia Mecatrônica e Sistemas Mecãnicos.

1. Service Design. 2. Service Engineering. 3. Design Engineering. 4. Requirement Engineering I. Universidade de São Paulo. Escola Politécnica. Departamento de Engenharia Mecatrônica e Sistemas Mecãnicos. II. t. 
Dedico esse trabalho primeiramente à Deus, minha família, Manoel e Inês, que nunca me deixaram perder a fé no meu proprio potencial; e minha amada Isadora, cujo suporte, carinho e paciência foram essenciais para o cumprimento da minha jornada. 



\section{AGRADECIMENTOS}

Primeiramente, gostaria de agradecer à Escola Politécnica da Universidade de São Paulo, que mais uma vez me acolhe como seu aluno. Todos professores e amigos que fiz por aqui foram esseciais para a minha formação pessoal e profissional. Serei eternamente grato a cada um.

Em segundo lugar, quero deixar registrado minha admiração e minha gradidão ao meu orientador professor Doutor José Reinaldo Silva. Além dos ensinamentos e provocações, vendo a ciência como ciclos de revoluções e não somente como métodos, teorias e empirismos simplistas, ele se tornou um verdadeiro mentor de vida para mim. Amadureci muito nesses ùltimos anos e agradeço muito cada conversa, como também cada chamada de atenção.

Não posso deixar de agradecer e citar meus grandes colegas do D-Lab. Valter Oliveira, cujo tabalho seminal trouxe ao D-Lab a ciência de Servicos, meu objeto de estudos hoje. Javier, Ariana e Nilberto, que a convivência, trocas e suporte no laboratório me ajudaram sempre a pensar diferente. Walter Lima, cujas conversas profundas sempre me fizeram pensar nos aspectos mais humanos das ciências exatas. E todos os outros que passaram pelo D-Lab e cujas generosidade academica sempre me enriquecedoras.

Gostaria também de agradecer ao meu grande amigo e parceiro Raul Javales, que de maneira muito gentil ajudou muito com a coleta de dados para o case principal desse trabalho, doando inclusive seu tempo aos finais de semana. Além disso, trouxe também críticas e sugestoes valiosas.

Não poderia deixar de lado meu grande amigo e sócio Miguel Chaves, que durante todos nossos anos de lealdade e companheirismo na condução do CAOS Focado, sempre me deu forcas e estimulo para a conclusão dessa jornada. Obrigado por me ensinar o real signinificado de resiliência e espirito empreendedor.

Agradeço também ao amigo e mais recente sócio do CAOS Focado, Lucas Torres, que com sua sobriedade e tranquilidade me inspira a ser um melhor líder e uma pessoa sempre mais mais justa.

E mesmo distante, não poderia deixar de agrader meus meio-irmãos Fernando e Shelly, que com muito amor e respeito sempre me apoiaram e me deram forças durante essa jornada. Tenho saudades de estar com vocês, mas o carinho, a admiração e o amor que tenho por ambos é algo que me alimenta sempre e me move para a ação.

Chego então a uma das pessoas mais importantes, que me dá apoio irrestirto, me encoraja e que com sua paciencia e carinho me ajudou a chegar até aqui. Obrigado minha companheira e meu amor Isadora. Sei que essa jornada não foi fácil para você também e te agradeço muito pela imensa compreensão em todos os momentos mais difícies. Eu te amo. 
Por último, os pilaes que me permitiram ser quem sou, as pessoas que mais acreditam em mim, que mais se preocupam e vibram com minhas vitórias, meus amados pais, Manoel e Inês. Meu mais imenso obrigado, por tudo que voces já fizeram e por todo suporte estrutural e emocional que vocês me deram durante todos esses anos. Tudo que sou, devo a vocês. Peço desculpas por minhas ausências e pelas faltas que cometi durante esse processo. Eu amo vocês de mais e mesmo com todo o percurso que a vida ainda há de me levar, eu estarei com vocês e por vocês. 


\section{RESUMO}

A partir da década de 1990, o campo das ciências de serviço vivenciou um grande crescimento, tendo o Marketing como campo acadêmico precursor, seguido pela área de gestão e logo depois pelo campo acadêmico da engenharia.

Desde ferramentas de negócios (ie, comércio eletrônico), passando por novas abordagens na prestação de serviços (por exemplo, tecnologia de autoatendimento baseada em TI, emissão de tickets e reservas on-line, acesso à conta bancária on-line, entre outras), novas formas de relacionar-se com clientes (por exemplo, e-Customer Relationship Management), os serviços baseados na Internet e TI levaram os pesquisadores a uma infusão de conceitos e técnicas relacionadas ã engenharia de software dentro do campo dos serviços (MOUSSA; TOUZANI, 2010).

Já o início de 2004 foi marcado pela introdução da lógica dominante de serviço (SDL), defendendo a transição de uma economia de trocas baseadas em bens para uma baseada em serviços. Além disso, no mesmo ano, a IBM lançou um "call to action"para uma iniciativa chamada Service Science, Management e Engineer (SSME), provocando uma maior formalização ao campo de pesquisa das ciências de serviço (MAGLIO et al., 2006).

Porém, hoje ainda pesquisadores e profissionais estão estudando e desenvolvendo maneiras de consolidar as teorias, leis e princípios das ciências de serviço, a fim de gerenciar e controlar os sistemas de serviços na prática.

Por outro lado, os Sistemas de Serviço são definidos como sistemas com uma intensa relação (ou colaboração) com o cliente. Esta característica de relacionamento colaborativo altera a idéia atual de serviços (baseada em bens): de um canal informacional unidirecional, para um intercâmbio de recursos múltiplos através de um processo adaptável com o cliente. Na verdade, esta mudança altera não apenas a forma como os sistemas de serviço são entendidos, mas especialmente como são projetados.

Em termos de impacto da lógica dominante de serviço sobre os diferentes setores econômicos, a indústria de manufatura acabou obtendo grande atenção de vários pesquisadores pelo mundo. (AURICH; MANNWEILER; SCHWEITZER, 2010; CAVALIERI; PEZZOTTA, 2012; TOMIYAMA, 2001). O campo de pesquisa de Engenharia de Serviços, que estuda o impacto da lógica de serviços sobre a manufatura, defende então a incursão do Design de Serviço no processo de fabricação, mudando inteiramente a idáia atual de uma cadeia de produção que se iniciava a partir dos insumos e matárias-primas vindas dos fornecedores, passando pela manufatura, atá a sua distribuição ao consumidor final.

No entanto, a nova perspectiva sobre serviços de manufatura compreende serviços que englobam os produtos, superando assim a no $\widetilde{A} \S \widetilde{A} £ o$ do design como projeto da função de um produto, para alcançar a ideia de design como o projeto 
da mudança de estado de um receptor.

Com o objetivo de apoiar a adaptação e o relacionamento intenso em busca de atender às necessidades individuais de cada cliente, uma proposta para um manufatura orientada à serviços deve ter como base tecnologias que trazem mais liberdade e flexibilidade ao processo de produção.

Um processo de produção para os serviços de manufatura deve ser, portanto, formado por um novo e sofisticado arranjo em rede conectados à internet, combinando máquinas inteligentes e colaborativas. A manufatura dessa maneira caminhará para uma proposta no qual fábricas inteligentes (virtuais) produz produtos inteligentes.

A Arquitetura de Produto-Serviço (ou apenas PSA) foi proposta pela primeira vez por (SILVA; NOF, 2015) com o objetivo de responder às necessidades de uma abordagem orientada a serviços para indústrias de manufatura.

Conforme definido pelos autores, o PSA é uma arquitetura distribuída no qual um provedor de serviços é definido como um conjunto aberto de unidades de produção (que poderiam fornecer produtos, servi $\tilde{A} \xi o s$ ou mesmo produtos / servi $\tilde{A} \S$ os) que poderiam ser independentes ou comercialmente conectados à empresa prestadora de serviços.

O PSA é portanto uma abordagem para tratar do problema dos Sistemas de Serviço a partir de uma perspectiva de Design, baseada em uma arquitetura de alto nível.

A abordagem de projeto atual para o PSA foi importada de tácnicas vindas dos Sistemas de Informação de Serviço, formando uma coleção de métodos de design e linguagens altamente conectados à abordagens orientadas a objetos e à arquitetura orientada a serviços (SOA).

No entanto, para alcançar a relação fornecedor-cliente, intensa e colaborativa, algumas melhorias na abordagem de design utilizando o PSA devem ser feitas a fim de permitir um projeto interno que poderia alcançar novas soluções que se adaptem às necessidades do cliente.

Nossa principal hipótese é de que os principais problemas estão concentrados nas fases iniciais do design. Por tanto, é necessário realizar modificações na disciplina de design atual do PSA em busca de abordagens mais conectadas à modelagem orientada à agentes que poderia oferecer as ferramentas necessárias para tal alteração.

A Engenharia de Requisitos Orientada para o Objetivo (GORE), portanto, surge como uma candidata importante dado que é uma abordagem de modelagem muito consistente e também fortemente baseada em conceitos orientados a agentes. Esta adiciona conceitos como goals e softgoals, que podem ser entendidos como uma representação alto nível dos interesse dos stakeholders. Assim, permitindo um novo espaço de análise capturado através da dimensão dos "porquês"dos stakeholders (YU, 1997).

Seguindo as representações de modelagem que buscam aumentar a agência 
com foco para uma possível aplicação na disciplina de design do PSA, o conceito de Intencionalidade, trazido pelo método GORE i*, que representa os interesses e motivação dos agentes, parece ajustar-se aos objetivos do design de serviço.

Portanto, apresentamos neste trabalho a nossa proposta para uma Disciplina Intencional para o Design de Serviço usando o PSA para apoiar a modelagem e o design de sistema de serviço que poderiam ser aplicados até mesmo em conjunto com novas abordagens para manufatura.

Para os fins desse trabalho, entendemos disciplina como um conjunto de regras, um código de conduta, envolvendo etapas e ferramentas, para alcançar um objetivo proposto. Discilpina, pois esta não admite formalismo que permita chamá-la de método. Portanto trata-se de uma proposta de base teórica conceitual que visa a incursão prática demonstrada pela melhoria do processo de modelagem. Logo, o que se quer demonstrar é que a reunião de passos, alinhado a um framework melhora a qualidade do pocesso. Não é possível formalizar completamente este método já que não há uma definição formal dos elementos (e nem memo de serviços). Note-se que ainda que a base conceitual do método baseado em intenções se encontra na fase preliminar da eliciação e análise de requisitos, que como se sabe não pode ser formalizada.

Buscamos portanto o enriquecimento da atual abordagem de disciplina de projeto usando PSA com abordagens orientadas por objetivos e intencionais para formar uma nova disciplina de design de serviços aplicada para a arquitetura PSA. 


\section{ABSTRACT}

From the 1990's onwards, service science field has experienced a great growth, taking the Marketing academic field as the precursor, next gathering Management and also Engineering academic field.

From business tool (i.e., e-commerce), new approaches in service delivery (e.g., IT-based self-service technology such as on-line ticketing and reservation, on-line bank account access, on-line package tracking, and so forth), and new ways of relating to customers (i.e., e-Customer Relationship Management), internet based and IT services prompted researchers to an infusion of Software Engineering concepts and techniques into Service field (MOUSSA; TOUZANI, 2010).

The beginning of 2004 was marked by the introduction of the service dominant logic (SDL), advocating a transition from an good-based exchange economy to a service-based one. Also, at the same year, IBM launched a call to action on the Service Science, Management and Engineer (SSME) initiative, pushing service research towards a more formal science field (MAGLIO et al., 2006).

Researchers and practitioners are studying and developing ways to consolidate service theories, laws, and principles in order to effectively manage and control service systems in practice.

On the other hand, Service Systems are defined as systems with an intense relationship (or collaboration) with the customer. This collaborative relationship characteristic changes the current (good-based) idea of services: from a one way informational channel, to a multiple resource exchange and adaptable process with the costumer. In fact, it changes not only the way service systems are understood, but specially how to design it.

In terms of the impact of the service dominant logic on different economic sectors, the impact over manufacturing industry had the attention of several different researchers over the world (AURICH; MANNWEILER; SCHWEITZER, 2010; CAVALIERI; PEZZOTTA, 2012; TOMIYAMA, 2001). The Service Engineering research field then advocate for the incursion of Service Design in manufacturing, changing entirely the current idea of a production chain transformation process from suppliers raw materials inputs until distribution to the final consumer.

However, the new perspective on manufacturing services understand services that encompass products, surpassing the notion of a product's function design, to reach a receiver's state change design.

To support adaptation and intense relationship to address customer individual needs, a manufacturing service initiative must be root on technologies that brings more freedom and flexibility into the production process.

A production processes for manufacturing services must be formed be a new sophisticated network arrangement supported by internet and combined with 
intelligent machines. In fact, manufacturing has to be supported to reach the concept of smart (virtual) factories producing smart products.

The Product-Service Architecture (or just PSA) was proposed firstly by(SILVA; NOF, 2015) with the objective of answering the needs for a serviceoriented approach to manufacturing industries.

As defined by the authors, PSA is a distributed architecture where a service provider is defined as an open set of production unities (which could deliver products, services, or even product/services) that could be independent or commercially connected to the service provider corporation.

It is an approach to address the problem of Service Systems from a Design perspective, based on an high-level architecture.

The current design approach for PSA is imported from the Service Information Systems, forming a collection of design methods and languages highly connected to object oriented and service-oriented architecture (SOA) approaches.

However, to achieve the provider-customer relationship, intense and collaborative, improvements on PSA design approach should be placed in order to allow an internal design that could achieve new solutions that adapt to meet the customer's needs.

Our main hypothesis is that major problems are on the early phases of the design. Modifying the approaches of the PSA design discipline to approaches more connected to agent-oriented modeling could offer the necessary tools to improve the service design using PSA.

Goal-Oriented Requirement Engineering (GORE) emerged as approach very consistent modeling approach strongly based on agent-oriented concepts. Adding the concepts of goals and softgoals to the design process, that could be understood as a high-level stakeholder objectives, it opened a new level of analysis capturing the "why" dimensions of the stakeholders(YU, 1997).

Following modeling representations to increase agency for the PSA design Discipline, the concept of Intentionality, brought by the GORE method i*, meaning interests and motivation of agents, seems to fit to the objectives of service design.

Therefore, we present on this work our proposal for an Intentional PSA Service Design Discipline to support modeling and design for service system that could be even applied to new manufacturing approaches.

For the purposes of this work, we understand discipline as a set of rules, involving steps and tools, to achieve a proposed goal. Discipline, as it does not admit a formalism that allows it to be called a method. Therefore, it is a theoretical conceptual proposal that aims practical incursions to demonstrated improvements of the modeling process. Therefore, what we want to demonstrate is that the steps gathered, aligned to a framework improves the quality of the design process. It is not possible to formalize it completely since there is no formal definition of the elements (even for services). It should be noted that the conceptual basis of the intention-based method lies in the preliminary stage of 
requirements elicitation and analysis, which as we know can not be formalized.

We seeks the enrichment of the current PSA design discipline approach with Goal-oriented and Intentional approaches to form a new Service Design Discipline applied for the PSA architecture. 


\section{LIST OF FIGURES}

1 Service Life-cycle. Figure created by author. . . . . . . . . . . . . 40

2 Service Design on Service Life-cycle. Figure created by author. . 42

3 Requirement Engineering and Service Design Engineering. Figure created by author. . . . . . . . . . . . . . . . 54

4 Manufacturing as pull production ............. 63

5 Service Orientation on Manufacturing . . . . . . . . . . . . . . 64

6 Production unities in a Service Provider combination. Adapted from $($ SILVA, 2014). . . . . . . . . . . . . . . 70

$7 \quad$ Product-Service Architecture. Figure created by author. . . . . . 71

8 Service Design Discipline Basis. Figure created by author. . . . . 75

$9 \quad$ First Service Design Discipline for PSA. Figure created by author. 77

10 Intentional PSA Service Design Discipline. Figure created by au-

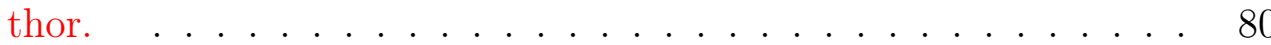

11 Development focus and Intention impact on PSA Service Design Discipline. Figure created by author. . . . . . . . . . . . . . 82

12 External Intentional Relationships. Adapted from (YU; MYLOPOULOS, 1998) . . . . . . . . . . . . . 84

13 Internal Intentional Features. Adapted from (YU; MYLOPOU-

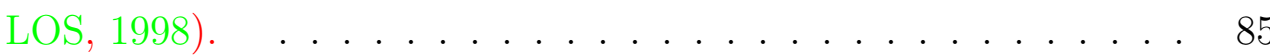

14 Intentions and Expectations. Figure created by author. . . . . . . 87 
15 System-as-is. Adapted from (YU; MYLOPOULOS, 1998). . . . . 89

16 Projection over a Space of Opportunity. Figure created by author. 90

17 First Expectation Model. Figure created by author. . . . . . . . 90

18 Expectation Influence Matrix. Figure created by author. . . . . . 91

19 Expectation Influence Model. Figure created by author. . . . . . . 92

20 Clustering Formation. Each color identifies a cluster following the algorithm. Figure created by author. . . . . . . . . . . . . . 93

21 Clustering Circuits Strategy. Figure created by author. . . . . . . 94

22 Expectation's clusters. Figure created by author. . . . . . . . . . 94

23 Service Generation. Figure created by author. . . . . . . . . . . . 95

24 Viewpoint Service Model. Figure created by author. . . . . . . . . 96

25 Service Collapsing Strategy. Figure created by author. . . . . . . 97

26 Collapsing Final Services - Part 1. Figure created by author. . . 98

27 Collapsing Final Services - Part 2. Figure created by author. . . 99

28 Primary System-to-be model. Figure created by author. . . . . . . 99

29 System-to-be model and Expectation set. Figure created by author.100

30 System-to-be model KAOS specification. Figure created by author. 100

31 Sampson's Health Care System Model. Extracted from (SAMPSON, 2012). . . . . . . . . . . . . . . . . 102

32 Application of ERi*c Method to Sampon's Health Care Model: Transforming tasks on goals . . . . . . . . . . . . . . . . 104 
33 Application of ERi*c Method to Sampon's Health Care Model: Final goals and softgoals for the SDsituation representing Health Clinic- Patient care . . . . . . . . . . . . . . . . 104

34 System-as-is for the Health Care System Model. A zoom view of internal elements. Figure created by author using TAOM4E modeling tool. . . . . . . . . . . . . . . . 105

35 Expectation Identification Process . . . . . . . . . . . . 106

36 Expectations over an Space of Opportunity. A zoom visualization of the model . . . . . . . . . . . . . . . . . . 107

37 Expectations Model of Health Care System. A zoom visualization of the model. . . . . . . . . . . . . . . . . . . . . 108

38 Positive Influence Matrix . . . . . . . . . . . . . . . . . . . 109

39 Clustering Circuits Strategy . . . . . . . . . . . . . . 110

40 Service generation Model. A zoom visualization of the model. . . 111

41 Collapsing Strategy for Health Care System . . . . . . . . . . . . 112

42 Final Services after Collapsing Strategy. A zoom visualization of the model. . . . . . . . . . . . . . . . . . . . 113

43 First System-to-be allocation. A zoom view on expectation. . . . 114

44 First KAOS modeling on System-to-be . . . . . . . . . . . . . . . 114

45 List of tasks of the stakeholders on the context . . . . . . . . . 116

46 Mold Production System-as-is . . . . . . . . . . . . . . . . . 117

47 Intention projection over an Space of Opportunity. A zoom visualization to capture only the expectations. . . . . . . . . . . 118 
48 Expectation Identification Model . . . . . . . . . . . . . . . . 119

49 Service Identification Model. A zoom visualization of the model. . 120

50 Service Collapsing Strategy _. . . . . . . . . . . . . . . 121

51 Service that optimize mold manufacture expectations. A zoom visualization of the model. . . . . . . . . . . . . . . . . . 122

52 First KAOS System-to-be Model. A zoom visualization of the model.123 


\section{LIST OF TABLES}

1 Portrayals emphasized in service's definitions . . . . . . . . . . 33

2 Services characteristics emphasized in service's definitions . . . . . 36

3 Reference Services and Service Life-cycle characteristics vs Service Design Approach fields . . . . . . . . . . . . . . . . . . . . 50

4 Attributes for a Reference Services Engineering Design vs Service Engineering Design Approaches . . . . . . . . . . . . . . . . . 62

$5 \quad$ Intentional Identification Phase Steps . . . . . . . . . . . . . . . . 101

6 Attributes for a Reference Services Engineering Design vs Service Engineering Design Approaches . . . . . . . . . . . . . . . 132

$7 \quad$ Reference Services and Service Life-cycle characteristics vs Service Design Approach fields . . . . . . . . . . . . . . . . . . 133 


\section{GLOSSARY}

D-Lab DesignLab - Universidade de SÃ£o Paulo

GDL Good-Dominant Logic

SDL Service-Dominant Logic

SSME Service Science, Management and Engineering

RE Requirement Engineering

GORE Goal-Oriented Requirement Engineering

PSA Product-Service Architecture

SOA Service-Oriented Architecture

$i^{*} \quad$ istar

NSD New Service Development

TQM total quality management

IT Information Technology

JOSM Journal of Service Management

JSM Journal of Services Marketing

JSR Journal of Service Research

e-SJ e-Service Journal

IJSTM International Journal of Services Technology and Management

PSS Product-service system

NFR Non-functional Requirements 
KAOS Keep All Objectives Satisfied

SOMF Service-Oriented Modeling Framework

SoftDiss Service Oriented Framework to the Design of Information Service System

SIS Service Information System

BP Business Process

UML Unified Modeling Language 


\section{CONTENTS}

1 Introduction 20

1.1 Motivation ........................ 21

1.2 Methodology ....................... . . . 23

1.3 Work's Objective .................... 25

1.4 Expected Contribution . . . . . . . . . . . . . . . 25

1.5 Work's organization . . . . . . . . . . . . . 26

2 Literature Review 28

2.1 Service Systems . . . . . . . . . . . . . . . . . . . . . . . . 28

2.1 .1 Service Science . . . . . . . . . . . . . . . . 28

2.1.2 Service System Definition . . . . . . . . . . . . . . 32

2.2 Service Design . . . . . . . . . . . . . . . . . . . . . . . . 37

2.2.1 Service Design Evolution . . . . . . . . . . . . 37

2.2.2 Service Design Definition . . . . . . . . . . . . . 38

2.2.3 Service Design approaches . . . . . . . . . . . . . 43

2.2.3.1 Marketing and Management Service Design . . . 43

2.2.3.2 Operations Management Service Design . . . . . 44

2.2.3.3 Manufacturing Engineering Service Design . . . . 45

2.2.3.4 Computer Science Service Design . . . . . . . . . 47 
2.2.3.5 Service Design approaches comparison . . . . . . 49

2.3 Requirement Engineering and Service Systems Design . . . . . . . 53

2.3.0.1 Requirement Engineering Evolution . . . . . . . 56

2.3.1 SOMF, Softdiss and Tropos as Service Engineering Design Approaches ....................... 59

2.3.2 Service Engineering Design Attributes . . . . . . . . . . 61

2.4 Service Systems applied to Manufacturing . . . . . . . . . . . . . 63

2.4.1 Infrastructure supporting a change toward a Service Manufacture ......................... 65

$\begin{array}{lll}3 & \text { Proposal } & 68\end{array}$

3.1 Product-service Architecture . . . . . . . . . . . . . . . . 68

3.2 PSA Design Discipline . . . . . . . . . . . . . . . . 72

3.3 Intentional PSA Service Design Discipline . . . . . . . . . . . . 78

3.4 Intentional Modeling . . . . . . . . . . . . . . . . . . . 83

3.5 From System-as-is to System-to-be: Introducing Expectations . . 85

3.6 Intentional Identification Phase . . . . . . . . . . . . 86

3.6.1 Expectation Model . . . . . . . . . . . . . . . . 88

3.6.2 Service Component Model . . . . . . . . . . . . . . . . 92

3.6.3 Intentional Identification Phase Summary . . . . . . . . . 101

3.7 Application of the Intentional PSA Service Design Discipline . . . 101

3.7.1 Health Care Service System Design . . . . . . . . . . . . . 102

3.7.2 Case Study: Manufacturing Industry System . . . . . . . . 115 
3.7.2.1 Intention Service Identification Phase . . . . . . 116

3.8 Chapter Conclusion . . . . . . . . . . . . . . . . . . 124

4 Results 126

4.1 Specific Results . . . . . . . . . . . . . . . . . . 127

4.1.1 Identification phase . . . . . . . . . . . . . . 127

4.1.2 Intentional approach for PSA . . . . . . . . . . . . . 129

4.2 General Results . . . . . . . . . . . . . . . . . . 131

4.2.1 Intentional PSA on Service Engineering . . . . . . . . 131

4.2.2 Intentional PSA on Service Life-cycle . . . . . . . . . . 133

5 Conclusion and Future Work 135

5.1 Improving the design capability of PSA . . . . . . . . . . 136

5.2 Increasing the capture of value co-creation on PSA $\ldots . . . .136$

5.3 Developing a consistent process of deriving system-to-be form the system-as-is on PSA . . . . . . . . . . . . . . 137

5.4 Future Work . . . . . . . . . . . . . . . . . . . . . 137

Referências 


\section{INTRODUCTION}

The emergence of Service Science highlight a paradigm shift from the perspective of consumption and value exchange, moving from an economy based on an exchanges of goods to an economy based on an exchange of services (VARGO; LUSCH, 2006; LUSCH; VARGO; WESSELS, 2008).

From a specific Marketing academic field, the service science have evolved to a scientific and industrial endeavor encompassing multiple viewpoints and objectives. In terms of manufacturing industry, service-dominant logic (SDL) lead to the emergence of a formal approach: the Service Engineering (QIU, 2014).

Service Engineering is more concerned with engineering solutions and how they could satisfy customers needs, than with the infrastructure that derive it production processes. In fact, the detachment between (service/product) solution and it production process start to be questioned (SILVA, 2014).

On the other hand, Service Systems are defined as systems with an intense relationship (or collaboration) with the customer. That relationship can be translated to three main features: co-design, co-production and (value) co-creation (DUTRA; OLIVEIRA; SILVA, 2014; DUTRA; OLIVEIRA; SILVA, 2013). In other words, the customer provides significant inputs to the design of the delivered product/service (co-design), to the production process itself (co-production) and, most important, to the generation of value created from the coupling between the delivered product/service solution and the customer(VARGO; LUSCH, 
2010; MAGLiO, 2009).

In order to meet those demands, Silva and Nof (SILVA, 2014) proposed a distributed architecture to product/service production arrangement based on a cloud system of systems. The Product-Service Architecture's (PSA) first proposal congregated a series of available and recent frameworks, methods and tools in order to design adaptive plans that combine the systems into an arrangement that attends clients expectations.

The main hypotheses of this work is that specifically for service systems, requirements modeling and analysis must include (value) co-creation, co-design and co-production including the core agents: end-users and direct affected stakeholders. This manifest for an adjustment on intentional design methods to improve actual service design approaches to provide an efficient Service Systems Design.

Those aspects demands for a new approach for PSA, reaching a new Design discipline: an Intentional Service Design Discipline.

The objective of this work is to implement a intentional approach on PSA, proposing a Intentional Service Design Discipline to the architecture.

\subsection{Motivation}

Practitioners and researchers have been facing important challenges concerning to the consolidation of service theories, laws, and principles. A great challenge that remains is the practical implications of service science. Since last decade, a great effort have been made in order to effectively manage and control service systems' behavior and effects to its stakeholder.

Service Systems are characterized by its intense collaborative relation with the customer. In fact, the customer gives significant input not only at the beginning of the process, he also do it during the service providing process. The service 
provider systems than has to anticipate the proper adaptation to a class of services - which normally appears in the design process as a customer feedback. That is a key issue to export the concept of service to other sector such as the manufacturing sector.

Therefore, service-oriented applied to manufacturing should now be understood as a distributed process that delivers a product/service, where production is a dynamic process that involves the perception and prediction of value creation on the final coupling process of solution and customer. That process generates customer feedback (co-creation) of intentions, or even customer intervention (codesign), that must be attended by a production process (co-production).

The Product-Service Architecture (or just PSA) was proposed firstly by (SILVA; NOF, 2015) and has been developed since then by Service Design research group at Design Lab in Escola Politecnica da USP. PSA aims to answer the needs for a service-oriented approach to product-based organizations experiencing a closer relationship between them and their customer, pushing its internal design to achieve new solutions that meet the different customer's needs.

However, to reach the intended value co-creation it is necessary to predict costumer satisfaction to be derived from the co-created value. Besides, co-production requires vertical integration and adaptive collaborative protocols in other to deliver the product-service to the final consumer.

Several technological advances in Artificial Intelligence and Multi-agent Systems indicates the valid proposition of an PSA implementation. However, also there is an emerging demand for design methods and platforms that could use the architecture to deliver and evolve service systems. In fact, a Design Discipline for PSA should cover the whole process of development - starting from requirements - that could be applied to service/product production systems. 
A Service Design Discipline for PSA is a sequence of design steps starting with the modeling of the System-as-is, that is, integrating all previous knowledge about the production system. Based on this model, intentions and expectations about a prospective System-to-be are captured which will be modeled on a service system using a goal oriented requirements approach.

However, in terms of the actual Design Discipline for PSA, there are key issues on early design phase and an Intentional approach using GORE methodologies seems to build a promising approach to provide a method to fit the design of production in a service delivery organization.

In fact, multiple issues and improvements could be analyzed on PSA in order to propose adaptations of the architecture. However, our main approach address the problem from a Design perspective, taking as a main hypothesis that major problems are on the early phases.

\subsection{Methodology}

In order to propose and analyze the contribution of a Intentional PSA Service Design Discipline, we will follow an exploratory strategy based on three phases: i) A study on Service and Service Design leading to an early definition of the Intention-Based Service Design Discipline for PSA; ii) Development and specification of the Intention-Based Service Design Discipline focusing on the early phases of the Design Process; iii) Application of the discipline in a Service Design study case through an action-research approach.

As our objective is to propose a discipline for the Design of Service Systems using the PSA architecture, a theoretical investigation is not enough, leading this research also to a deepening on modeling languages, its methods and design tools. Basically, the first phase address theoretical investigation and practical (design) 
activities on the following main lines: (a) a basic study of the (recent) history of Service and Service Design; (b) an study of attempts to organize Service Design Process and proposals to represent users; (c) an study of new methods of design generically applied such as GORE (Goal Oriented Requirements Engineering).

The perception of how proposed features work is also important since there is no formal description of service so far. That is, there is no formal theory of Service. Therefore some specific work directed to the application of Service Design allowed the development of what we call perception of the problem. This lead this work to an exploratory approach mixing practical activities with the consolidation of a theoretical formulation (at least the minimum set necessary to reach our main design goal).

After an extensive literature review - which always need to be revised - and two practical incursions on Service Design, a Service System definition and a reference Service Life-cycle were proposed, in order to guide the analyze of the current PSA and the following improvements on its Design Discipline.

The Intentional PSA Design Discipline supported by GORE and intentional methods is proposed enriching and adapting the current PSA Design Discipline, inherited from Oliveira's primary work on service design (OLIVEIRA; SILVA, 2015).

That Intention-Based Service Design Discipline is then specified focusing specifically on requirements, modeling and analysis phases from the reference Service Life-cycle. The characteristics of service system, (value) co-creation, codesign and co-production, were used as a guideline for the discipline.

Following our exploratory strategy, the discipline was applied on Service Design study cases and enriched through a action-research approach, whose research cycle improves practice by systematic dialogue between practice and theoretical 
research.

This approach was conducted using reference models and a real case. The results were then analyzed through the lens of service life-cycle and service characteristic satisfaction. The analysis is based on a comparison of the new Service Design Discipline with the previous PSA discipline and selected Service Design approaches.

\subsection{Work's Objective}

The objective of this work is to implement a intentional approach on PSA, proposing a Intentional Service Design Discipline to the architecture.

As specific objectives, this work intends:

- An increase of the capture of value co-creation variables in the ProductService Architecture, by including a goal-oriented modeling techniques, especially focusing on modeling agents' intentions.

- To develop a consistent process of deriving a system-to-be from a systemas-is so that it also fills the gap of a non-existent system-as-is in the current version of the Product-Service Architecture.

\subsection{Expected Contribution}

We are going to analyze the expected contributions on two different perspectives, a specific and a general.

In terms of specific results, the aim of this work is to contribute with:

- A consistent identification phase ${ }^{1}$ for the Design Discipline, as the others

\footnotetext{
${ }^{1}$ It is the phase extract an requirement model from an context model. It will be better presented on the following sections
} 
approaches target unsatisfactorily the early phase of the Service Life-cycle.

- Improvement on the overall satisfaction of Service Characteristics due to the introduction of an intentional approach for the PSA.

For the general results we expect contributions on:

- Service Design Engineering related to an approach applied, not only to classic services, but also to Manufacturing Services design.

- Service Life-cycle current approaches related to the proposition of the Intentional approach of PSA, resulting on a best coupling process between provider and customer.

\subsection{Work's organization}

This first introduction chapter contains the work motivation, its expected contributions and the methodology used to reach the research objectives.

The second chapter will present the review of the main concepts of service science, the recent development and initiatives for service systems and will present the chosen definition for the purpose of this work. Besides a literature review on Service Design and recent academic initiatives related also to Requirement Engineering, the second chapter will present also developments on Goal-oriented Requirement Engineering (GORE) methodology, and will explore the literature on service system applied to manufacturing systems.

The third chapter contains the research advancements on PSA and presents its original structure. Also, this chapter introduce the notion of Intentionality through Eric Yu's i* point-of-view and defines the element "expectation". That 
is what forms the base for the introduction of the Intentional PSA Service Design Discipline. On the same chapter we explore the two design study cases using the Intentional PSA discipline.

On the fourth chapter we analyze the results concerning a comparative analysis with the original PSA discipline and others selected approaches, presented on chapter 2.

On the fifth, and last chapter we conclude analyzing the general and most important advancements of the new Design Discipline and explore the needs for future works. 


\section{LITERATURE REVIEW}

\subsection{Service Systems}

\subsubsection{Service Science}

Based on an extensive literature, Fisk, Bitner and Brown (FISK; BROWN; BITNER, 1993), followed by Moussa and Touzani (MOUSSA; TOUZANI, 2010), presented an evolution of the service field from the early 80's until the beginning of 2010 .

The history of the service field date back to the early 1980s taking the Marketing academic field as the precursor of services studies (FISK; BROWN; BITNER, 1993).

After 1993, the number of service articles appearing in leading marketing and management journals have raised. Firstly noted by special sections/issues emergence on those journals, and later, by dedicate service journals arrivals Journal of Service Management (JOSM), Journal of Services Marketing (JSM) and Journal of Service Research (JSR) (MOUSSA; TOUZANI, 2010).

However, from 2000 to 2003, the service scientific field faced a conceptual crises expressed by several concerns and fears about the state and future of the field. On that time, it started to diffuse with others disciplines besides marketing, as cited by Grove (GROVE; FISK; JOHN, 2003): 
Service marketing now faces a challenge that confronts many maturing fields of study...Specifically, as the domain of services has expanded, the boundaries that define it have become less obvious. Further, like so many other evolving disciplines, the direction in which services marketing is headed is somewhat unclear. Issues regarding the scope and the future of services persist. In short, as the field has grown, it has also become more diffuse. A basic question now facing the services marketing sub-discipline is 'where do we go from here?'

Due to the fields proximity, Management and Marketing got closed quickly than Engineering field. Pushed by service operation's problems, the Production and Operations Management Society created a special college to study services. On the other hand, even if it was not seen as a research field on engineering, service sector started to rise pushed by IT and especially the Internet during the late 1990s.

From business tool (i.e., e-commerce), new approaches in service delivery (e.g., IT-based self-service technology such as on-line ticketing and reservation, on-line bank account access, on-line package tracking, and so forth), and new ways of relating to customers (i.e., e-Customer Relationship Management), internet based and IT services prompted researchers to an infusion of Software Engineering concepts and techniques into Service field (MOUSSA; TOUZANI, 2010).

That infusion culminated on International Journal of Services Technology and Management (IJSTM) and e-Service Journal (e-SJ) creations, in 2000 and 2001 respectively, putting (software and computer) engineering on the network of service research.

The beginning of 2004 was marked by the introduction of a number of new important concepts and paradigms that spread into the most influential service 
conferences and prepared a new step of scientific production on services.

One of the most important contribution was the eruption of a "new dominant logic" for the theory and practice of marketing (VARGO; LUSCH, 2004). The service dominant logic (or just SDL), proposed firstly on the marketing fields by Vargo and Lusch, had a important impact through all Service Science productions branches since. The article by Vargo and Lusch (2004) is placed as the most cited JM article for the period from 2000 to 2009 (MOUSSA; TOUZANI, 2010).

In fact, SDL presents a paradigm shift that advocates a transition from an economy based on goods exchange to one based on services. A change of a "good-dominated view in which tangible output and discrete transactions were central, to a service-dominant view in which intangibility, exchange processes, and relationships are central" (VARGO; LUSCH, 2004).

After 2004, the service orientation paradigm shift reached even more important space in engineering research, specially after the important investment of IBM in service research, pushing it for a real science of service (MAGLIO et al., 2006). IBM launched the Service Science, Management and Engineer (SSME) initiative through a call to action. The major goal of the initiative were (STANICEK, 2009):

- to become more systematic about innovation in services;

- to complement product and process innovation methods, and

- to develop a "science of services"

IBM defines SSME as follows (IBM, 2008):

The emergence of Service Science or Service Science, Management and Engineering (SSME) is a story of gradual identification of numerous areas of study: service economics, service marketing, service 
operations, service management, service engineering, service computing, service sourcing, service human resources management, service design, and more [...]. Despite important developments in the service field over recent decades, there has been a growing perception that a more integrated approach is needed if real progress is to be made.

From 2005 to 2010, the number of service-related journals more than doubled (from 9 to 20) according to Moussa (2010). Furthermore, the attention by practitioner and several academic institutions around the world have increased. Industrial leaders like Hewlett Packard, Oracle, Accenture, Electronic Data Systems, and British Telecom have also set up their own service science agenda. A growing number of university-affiliated service centers and academic-oriented networks have being established around the world (e.g., California Center for Service Science, Center for Service Management at Loughborough University, and the Latin American Service Research Network) (OSTROM et al., 2015).

According to Ostrom (2015), "the importance of service research and the need for new service-related knowledge have never been greater".

On a recent study for a research agenda priority to the field, Ostrom (2015) applied a survey with more than 330 service researchers from 37 counties, finding 12 broad researches priorities topics and 80 related topics (OSTROM et al., 2015). The topics "Leveraging Service Design", "Understanding Value Creation" and "Measuring and Optimizing Service Performance and Impact" are examples of the research topics outputted from Ostrom's work.

In summary, the science of service, or service science, have evolved from a specific Marketing academic field to a scientific and industrial endeavor encompassing multiplier viewpoints and objectives. Its challenges are to consolidate service theories, laws, and principles to be applied in practice, that can effec- 
tively manage and control the behavior and effects of the service systems to its stakeholder.

\subsubsection{Service System Definition}

The challenge faced by scholars on the definition of a Service System is well described by (SAMPSON; FROEHLE, 2006) when he poses a simple question:

How can we rationalize simultaneously encompassing business processes from health care and garbage collection, consulting and ski resorts, airlines and pawn shops, pet grooming and architecture firms, universities and butcher shops?

An extensive list can be made to exemplify what is common sense about services: automobile repair, hair styling, information technology (IT) outsourcing, business consulting and so on. And ideally, service concepts and frameworks should provide a unified view of how services are produced, delivered, and used or consumed. However, most of service wide and inclusive definitions revels, in practice,to be not so useful (WANG et al., 2013; SAMPSON, 2010).

Even assuming that service definitions are not universally right or wrong, and recognizing that each single definition (form different service researchers) makes sense from a particular viewpoint or in a context, it would be nice to have one definition that actually covers most everyday services. Alter (2014) (ALTER, 2014), for example, defines a single abstract definition and several others conceptual models in different layers in order to balance theoretical and practical use of definitions and models.

Using Qiu's (2014) (QIU, 2014) five core elements to extend the portrayal of definition's table from (ALTER, 2014) (Table 1, p. 3), a new service definition's table shown in table was conceived 1. 
Table 1: Portrayals emphasized in service's definitions

\begin{tabular}{|c|c|}
\hline Portrayal & "Definition \\
\hline $\begin{array}{l}\text { customer, provider and } \\
\text { resource }\end{array}$ & $\begin{array}{l}\text { "A system is a configuration of resources, including } \\
\text { at least one operant resource, in which the prop- } \\
\text { erties and behavior of the configuration is more } \\
\text { than the properties and behavior of the individual } \\
\text { resources." (MAGLIO et al., 2009) }\end{array}$ \\
\hline $\begin{array}{l}\text { customer, provider and } \\
\text { resource }\end{array}$ & $\begin{array}{l}\text { "service systems are dynamic configurations of re- } \\
\text { sources that can create value with other service } \\
\text { systems through shared information" (SPOHRER } \\
\text { et al., 2007) }\end{array}$ \\
\hline process & $\begin{array}{l}\text { the "application of skills and knowledge (oper- } \\
\text { ant resources) for the benefit of another party" } \\
\text { (LUSCH; VARGO; WESSELS, 2008) }\end{array}$ \\
\hline process & $\begin{array}{l}\text { "A service is a function that is achieved by an in- } \\
\text { teraction between a human and an entity under a } \\
\text { protocol." (WANG et al., 2013) }\end{array}$ \\
\hline process & $\begin{array}{l}\text { "services is a type of process and services are mul- } \\
\text { tiple service processes" (SAMPSON, 2010) }\end{array}$ \\
\hline process & $\begin{array}{l}\text { "a provider-client interaction that creates and cap- } \\
\text { tures value." (IBM, 2008) }\end{array}$ \\
\hline value & $\begin{array}{l}\text { "a time-perishable, intangible experience per- } \\
\text { formed for a customer acting in the role of a co- } \\
\text { producer." (Fitzsimmons, J. Fitzsimmons, 2013) }\end{array}$ \\
\hline value & $\begin{array}{l}\text { "value co-creation configurations of people, tech- } \\
\text { nology, value propositions connecting internal and } \\
\text { external service systems and shared information" } \\
\text { (VARGO; LUSCH, 2010) }\end{array}$ \\
\hline value & $\begin{array}{l}\text { "value-creating support to another party's prac- } \\
\text { tices." (GRONROOS, 2011) }\end{array}$ \\
\hline value & $\begin{array}{l}\text { "service systems are customer intensive systems } \\
\text { (...) where: (1) the customer does not control most } \\
\text { of the means of the production of the system; }(2) \\
\text { the customer is a significant part of the input to } \\
\text { the system." (PINHANEZ, 2008) }\end{array}$ \\
\hline value & $\begin{array}{l}\text { "A service system comprise people and technolo- } \\
\text { gies that adaptively compute and adjust to a sys- } \\
\text { tem's value of knowledge" (STANICEK, 2009) }\end{array}$ \\
\hline
\end{tabular}


Each definition portray service in three different guises in the column in table 1 called portrayal. Some definitions focus more on entities that compose a service system (customer, provider and resource) and its dynamical relationships. Others, focus more on service systems as process or acts performed by service providers. At lest, some others focus more on outcomes perceived by customers (or value within the process).

Therefore, following Alter's definition strategy (ALTER, 2014) (p. 3) and combining with Qiu's (QIU, 2014) five core elements represented on the portrayals on the definition's table, a simple service definition can be proposed:

"A service is a process performed by a service provider, that, through resources, produce value for the benefit of a customer."

Indeed, no matter how small or big, simple or complex a service is, those elements of the definition will apply. It apply to person-to-person and organizationto-organization services.

Besides the broad initial definition, in service literature there are common accepted generalizations about aspects of services that typify different configurations of the possible provider-consumer interactions during the service life-cycle.

Service Systems are processes with an intense relationship (or collaboration) with the customer. That relationship can be translated into three main characteristics: (value) co-creation, co-production and co-design (DUTRA; OLIVEIRA; SILVA, 2013; DUTRA; OLIVEIRA; SILVA, 2014). In other words, the customer provides significant inputs to the generation of value created from the coupling between the delivered product/service solution and the customer, to the production process itself (co-production) and, to the design of the delivered product/service (co-design). 
Table 2 presents service systems' characteristic description related to those three characteristics.

Therefore, besides a general definition, those characteristics are a useful as a complement and as a generalization of the interactions on service systems.

Essentially, considered as an "act of performing" or a process, it beneficial activity to create value depends on customer perception of value. During providercustomer interaction, service providers may have opportunities to co-create value. Quite often, a service evidently manifests itself as a series of service encounters in the marketplace.

Customers may or may not be co-producers on services, however, the supply chain of services, inside or outside the service provider, has to co-produce in order to create value from the performance of the formed service encounters chain.

No matter what kind of service is offered, the service shall be seen in it complete lifecycle, from its initial conception to its evolution. Service design is also an intense relationship (or collaboration) with the customer, in order to co-design the value proposition of the service system.

Evidently, the consumer and the provider of the service shall interact with each other, directly or indirectly, consecutively or intermittently, physically or virtually, and briefly or intensively, during the process of performing the service lifecycle.

Therefore, we must add to the first definition, the general characteristics that qualify the interaction process between provider-customer:

"A service is a process performed by a service provider, that, through resources, produce value for the benefit of a customer. Service systems are process that apply for (value) co-creation, co-production 
Table 2: Services characteristics emphasized in service's definitions

\begin{tabular}{|c|c|}
\hline $\begin{array}{l}\text { Service Charac- } \\
\text { teristic }\end{array}$ & Definition \\
\hline value co-creation & $\begin{array}{l}\text { "Value co-creation means a mutual co-operation between the } \\
\text { provider and the customer.(...) All those knowledge and infor- } \\
\text { mation sharing is materialized during consultations and ne- } \\
\text { gotiations which are frequent at the beginning of the process, } \\
\text { but which continue through all the process." (STANICEK, } \\
\text { 2009) }\end{array}$ \\
\hline value co-creation & $\begin{array}{l}\text { "Customers of services create value for themselves. Service } \\
\text { providers may have opportunities to co-create value." (AL- } \\
\text { TER, 2014)(BP2, p. 13) }\end{array}$ \\
\hline value co-creation & $\begin{array}{l}\text { "service is value co-creation interactions undertaken when ser- } \\
\text { vice systems create, propose, and realize value propositions, } \\
\text { which may include things, actions, information, and other re- } \\
\text { sources." (IBM, 2008) }\end{array}$ \\
\hline co-production & $\begin{array}{l}\text { "Customer-self inputs are common, for example, in services } \\
\text { involving co-production (i.e., the employment of customer la- } \\
\text { bor in the process) and in services involving the physical pres- } \\
\text { ence of the customer." (SAMPSON; FROEHLE, 2006) }\end{array}$ \\
\hline co-production & $\begin{array}{l}\text { "The service value chain framework incorporates characteris- } \\
\text { tics often associated with services, such as coproduction by } \\
\text { providers and customers." (ALTER, 2008) }\end{array}$ \\
\hline co-production & $\begin{array}{l}\text { "A value network is a spontaneously sensing and responding } \\
\text { spatial and temporal structure of largely loosely coupled value } \\
\text { proposing social and economic actors interacting through in- } \\
\text { stitutions and technology, to: (1) co-produce service offer- } \\
\text { ings, (2) exchange service offerings, and (3) co-create value" } \\
\text { (LUSCH; VARGO; TANNIRU, 2010) }\end{array}$ \\
\hline co-design & $\begin{array}{l}\text { "It involves the participation in the creation of the core of- } \\
\text { fering itself. It can occur through shared inventiveness, co- } \\
\text { design, or shared production of related goods, and can oc- } \\
\text { cur with customers and any other partners in the value net- } \\
\text { work."(LUSCH; VARGO, 2006) }\end{array}$ \\
\hline co-design & $\begin{array}{l}\text { "Involving customers through participatory design and code- } \\
\text { sign to enhance service experience" (OSTROM et al., 2015) }\end{array}$ \\
\hline co-design & $\begin{array}{l}\text { "participatory design and co-design (...) generally empha- } \\
\text { size the necessity for all stakeholders and development team } \\
\text { members to understand end users and real usage contexts." } \\
\text { (HUANG et al., 2013) }\end{array}$ \\
\hline
\end{tabular}


and co-design characteristics."

\subsection{Service Design}

\subsubsection{Service Design Evolution}

The first scientific studies about service development starts at 1990's (MOUSSA; TOUZANI, 2010) when terms such as "Service Design", "New Service Development" and "Service Engineering" appeared in the literature (CAVALIERI; PEZZOTTA, 2012). While the broader concept of New Service Development (NSD) describes the overall process of developing new services, service design has been viewed as an specific stage of the this whole process(EDMAN, 2011; PATRICIO et al., 2011; GOLDSTEIN et al., 2002).

In the early research, service design was related to different service mapping techniques due to its process/flux characteristic. The growth of total quality management (TQM) at the time had impacted on service development research (BROWN; FISK; BITNER, 1994) and other proposals as service blueprint (BITNER; OSTROM; MORGAN, 2008; BROWN; FISK; BITNER, 1994) and customer contact model (CHASE; APTE, 2007), giving grater importance on the customer interaction, had emerged.

Later, in 2000, service academics and practitioners have moved to use customer relationship management as a foundation for a new approach to strategy (MOUSSA; TOUZANI, 2010), and an engagement of practitioners with design background leaded to the emergence of another design discipline: Service Design (MAGER, 2009a), or even Design for Services (WETTER-EDMAN et al., 2014) highlighting a perspective of the contribution of design into service system development.

At the same frame time, researchers in Germany (AURICH; MANNWEILER; 
SCHWEITZER, 2010) and Japan (TOMIYAMA, 2001), looked for a more formalized approach to the manufacture industry, influenced by what some calls "servitization" (SCHMENNER, 2009; BAINES, 2015). That design perspective brought traditional engineering approaches to the service sector adapting them to the hybrid product-service system (PSS) (SAKAO; MIZUYAMA, 2014).

From another perspective, in 2004, with IBM's Service Science, Management and Engineering (SSME) initiative (IBM, 2008), several computer sciences initiatives based on e-services started to integrate a broader body of knowledge of the Service Science (MOUSSA; TOUZANI, 2010). In terms of service design, a very popular architecture between practitioners, the service-oriented architecture (SOA) (ERL, 2008; HURWITZ et al., 2007), have been gaining attention on the research community (BARDHAN et al., 2010; RALYTÉ; KHADRAOUI; LÉONARD, 2015).

All those different branches adds different methodologies, languages and tools for the Service Design topic. There is a need to explore those several characteristic to find convergences and divergences in order to propose a new Service Design Discipline.

\subsubsection{Service Design Definition}

Service Design is the activity responsible for modeling and specifying the service system that effectively cover a set of objectives current called service requirements. In other words, this means that a set of requirements exists which could be fulfilled only by a generic process and not by an encapsulated device or system (which would be generically called a "product"). Thus, to find a better solution, or the best set of processes satisfying the requirements, a design process is the key issue. It provides a strategic way to organize the interaction and collaboration among people, machines, resources, and inputs, and to get the 
proper output or effect (the final state - value creation).

In order to understand Service Design it is necessary to frame it on the whole service life-cycle.

In literature, there are many versions of phases composing a service life-cycle. Regardless the many existing versions, the proposed by Qiu (QIU, 2014) and by SCube European initiative (ANDRIKOPOULOS, 2009) seems the most complete ones. Based on both, from a service provider point of view, the service life-cycle on fig. 1 is composed of three essential cycles ("Reference Cycle", "Evolution Cycle" and "Satisfaction Cycle" ) and three transitions phases ("Identification", "Realization" and "Innovation"). Service life-cycle represent the process of the interaction between the whole service system (since its conception's models to its operations) with what we generally call "world" (including system's domain boundaries, that could be reference models, informal documentations, but normally it is formed by all stakeholders). In terms of attention element during each cycle, the Reference Cycle is focused on the development of a system-as-is model, the Evolution Cycle on a system-to-be model and the Satisfaction Cycle on the management, adaptation and optimization of a instance, or a new instance, of the service system.

The three cycles and three transitions are briefly discussed as follows:

- Reference Cycle: It is a cyclical (iterative) modeling phase that, through information gathering of the world, models the context on a system-as-is representation. The System-as-is is a reference model of the current way in which a group of actors deal with a particular situation. It represents the context, actors, stakeholders, intentions, objectives, plans, actions, interactions and resources of the specific domain. It inputs can be through a non-formal or semi-formal process of stakeholder's interviews, a documen- 


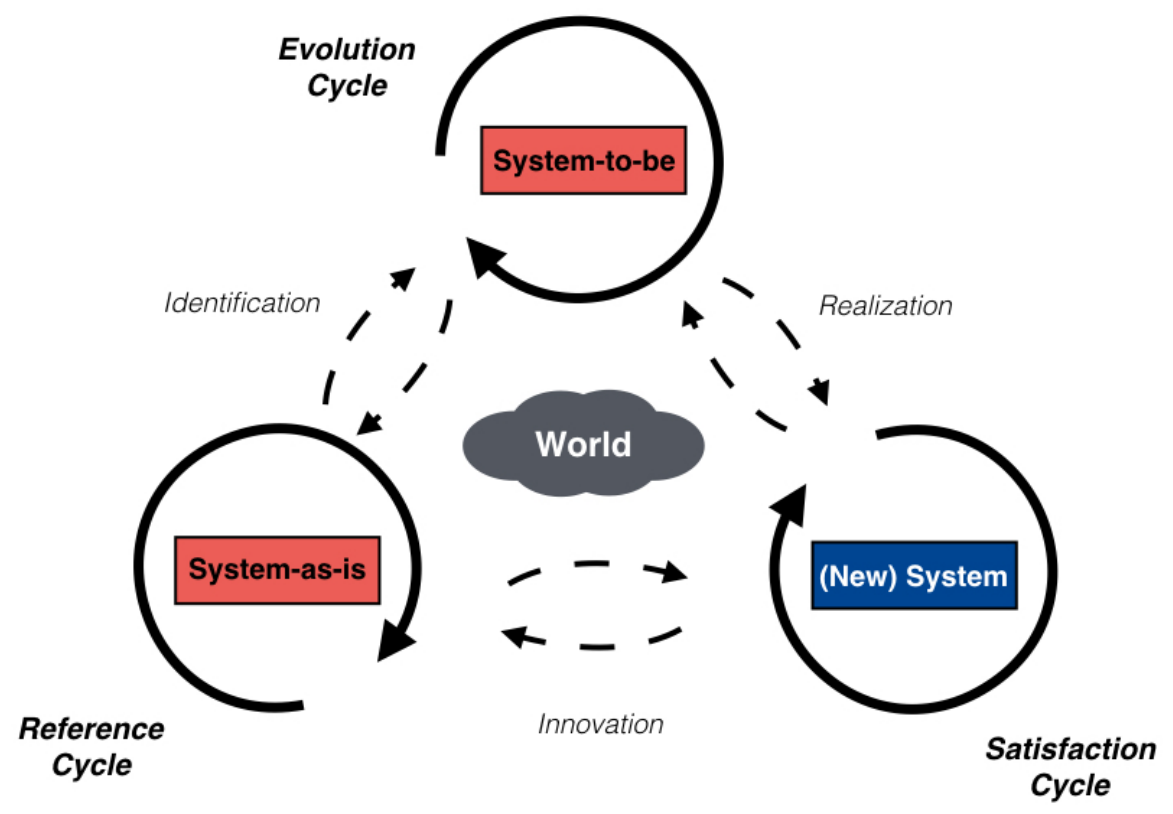

Figure 1: Service Life-cycle. Figure created by author. 
tation review of the established situation/system, or a formal older version of the system-as-is. It outputs a coherent and complete system-as-is model.

- Identification: It is a transition phase from the system-as-is to the systemto-be. Needs and opportunities (requirements) are identified on the first model and, through generation and selection, a set of hi-level service systems that should attend those requirements is proposed.

- Evolution Cycle: It is a cyclical (iterative) modeling phase that, through a first hi-level identified service solution, models and analyze a service system on a system-to-be specification. The system-to-be is a coherent model of the service system that completely attends to the needs and opportunities gathered by the system-as-is or directly in the world. It inputs could be a first identified service system proposition from the identification transition and/or a requirement model extracted directed in a interaction with the world. As an output, the system-to-be has to be specified in a way its structure and behavior have been validated and analyzed formally.

- Realization: It is a transition phase from the system-to-be to the new service system. The realization instantiate the proposed system in the real world. In other words, it implements it on machine systems, information systems and business structures. In fact, its interaction with the world (thought prototyping, simulations or mock-ups) and verification accordingly with the system-to-be, generates a first stable service system as output.

- Satisfaction Cycle: It is a cyclical (iterative) modeling phase that perform, optimize, manage and adapt the system accordingly to a satisfaction measurement of the service value creation. All the service touch-points with the customer and the arrangements of the sub-services systems are analyzed and improved in order to reach the maximum value co-creation level. 
As input, it receives a first stable service system implementation and it outputs a complete hi-performing service system.

- Innovation: It is a transition phase from a current service system that, among many reasons, do not attend customer expectations in terms of value creation. It transform the current system in a system-as-is model in order to start a new whole service life-cycle.

In order to place Service Design into Service Life-cycle, the overlapped configuration of Requirements and Design, proposed by Jarke and al (JARKE et al., 1993), was expanded and is represented on fig. 2.

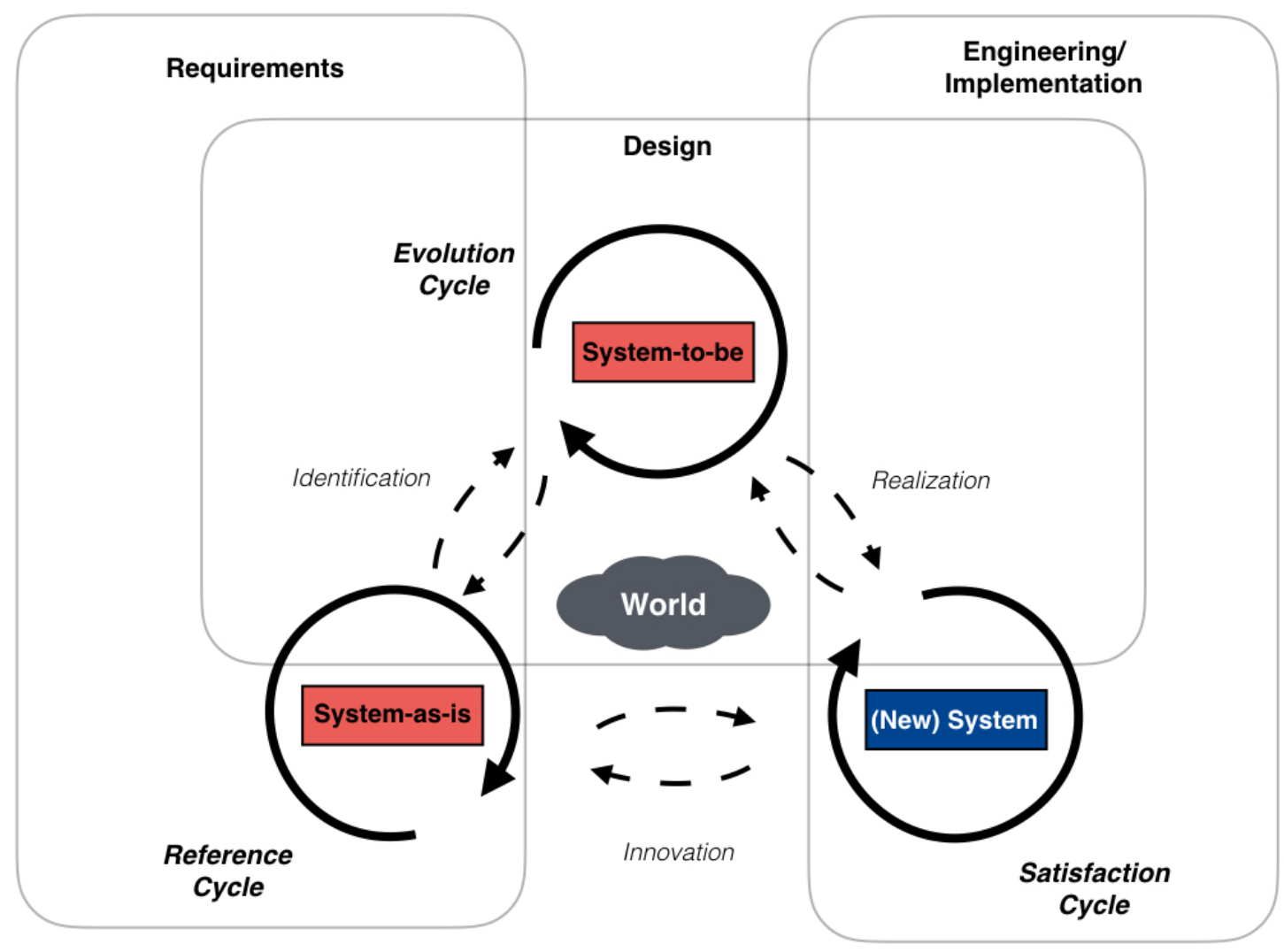

Figure 2: Service Design on Service Life-cycle. Figure created by author.

Therefore, Service Design is defined as a part of the service life-cycle centralized on the evolution cycle (service solution system modeling and analysis) which 
overlap requirement and engineering on identification and realization transition phase respectively.

\subsubsection{Service Design approaches}

In terms of Service Design approaches, researches initiatives respects the same differentiation of the Service Science viewpoints: (i) Marketing and Management, (ii) Operations Management, (iii) Manufacturing Engineering and (iv) Computer Science.

\subsubsection{Marketing and Management Service Design}

From a Marketing and Management perspective what stands out is the active and vibrant research and practice-based community formed by members from several institutions.

Brigit Mager, the first professor in service design at Koln International School of Design (Germany), is one of the most important researcher on that community. She is responsible for the creation, in 2009, of the magazine called "Touchpoint, The Journal of Service Design"(MAGER, 2009b).

Besides Koln International School, the academic community is formed also by members of Carnegie Mellon University (USA), Linkopings Universitet (Sweden), Politecnico de Milan/Domus Academy (Italy), and agency Spirit of Creation (UK) (BLOMKVIST; HOLMLID, 2010).

From the practitioners on service design, consulting firms and design agencies such as IDEO, Continuum or the British live|work (MAGER, 2009a; EDMAN, 2011; MORITZ, 2005), apply successfully principles and methods through multiples different clients. Some times blurring the boundaries with what some calls Design Thinking practice (Wetter Edman, 2009). 
In fact, for the service design from marketing and management perspective there is no reference method or tool. There are several frameworks that guides the design team from information gathering, passing though idea generation reaching the first phases of prototyping and user feedbacks. However, there is a special focus on co-design with the stakeholders in order to capture a sensible aspect of them to design value co-creation experiences.

Researchers on that viewpoint of Service Design are exploring a deeper understanding of value co-creation through participatory design (HALSKOV; HANSEN, 2015) and visualization process (BLOMKVIST; HOLMLID, 2010).

\subsubsection{Operations Management Service Design}

Analyzing Service Design through the lens of Operation Management means to analyze what its known as Service Operations or even Service Delivery Process (CHASE; APTE, 2007).

From a Customer Contact Model (CHASE; APTE, 2007), passing thorough total quality management (TQM) influence on SERVQUAL (PARASURAMAN; ZEITHAMAL; BERRY, 1985), service profit chain framework (HESKETT et al., 2008) and new adaptations of the Blueprint model (BITNER; OSTROM; MORGAN, 2008; BROWN; FISK; BITNER, 1994), the Operations Management, from the perspective of service design, have been proposing several ways to examine "the operational processes and choices that are required to deliver value" (VOSS; HSUAN, 2011).

In fact, besides the occupation on integrating (or outsourcing) efficiently investments in numerous assets, processes, people, and materials, the field also have a special care on customer perception of value, translated on service quality perception (GOLDSTEIN et al., 2002). 
Important design concepts as front-office and back-office operations and loyalty relationship are at the center of that service design exploitation.

More recent researches are advancing on the design of service engaging experience treating more sensorial stimulation and even emotional ones during service operation (ZOMERDIJK; VOSS, 2010).

\subsubsection{Manufacturing Engineering Service Design}

Through a Manufacturing Engineering viewpoint, Service Design started to gain importance since "servitization" term did it incursion in the Manufacturing field at the end of the 80's (SCHMENNER, 2009). In fact, manufacturing movement to services is "mainly motivated by a continuous strive to create new sources of value for the company" (CAVALIERI; PEZZOTTA, 2012). That approach, seen as an strategic shift, aims a closer relationship between the manufacturer and the customer, pushing the design of new solutions to meet the customer's needs. However, in the mid-1990s, an evident lack of research with more systematic approaches boosted the emergence of Service Engineering field. Cavalieeri, S. and Pezzotta, G. states:

"Service Engineering aims to apply the engineering-scientific know-how to develop Service Systems and Product-Service Systems in a systematic and methodological way."

In fact, the first research initiatives on Service Engineering started in Germany (AURICH; MANNWEILER; SCHWEITZER, 2010) and Israel (CAVALIERI; PEZZOTTA, 2012). Nevertheless, Japanese manufacturing researchers also followed the incursion of Service Design in manufacturing some years after (TOMIYAMA, 2001; SHIMOMURA; NEMOTO; KIMITA, 2014).

This conceptual shift in manufacturing field represents not only a superficial 
or additional change, it reaches the most stablished principles of its design:

"Traditionally, engineering design has aimed to improve only functions. A better function of a new product, we have believed, makes consumers satisfied. In (Service Engineer), however, not only the functions of artifacts but also the meaning of contents must be matched to the specifications given by receivers; only then will the satisfaction level of receivers increase. (...) The critical concept in (Service Engineer) is not the function of a product, but rather the state change of the receiver. (SAKAO; HJELM, 2010)"

However, the alternative chosen by those researchers was not for an abstract definition of services encompassing product, they followed the path of value creation by highly integrating products and services. Therefore, in Service Engineering, the focus of design are Product-Service Systems (PSS) (CAVALIERI; PEZZOTTA, 2012).

Although, in terms of PSS Design there is no agreement between the researchers, some optimization and quality control techniques, already used on manufacturing context, have been adapted for this new context. Methods as Quality-Function Deployment (QFD), TRIZ, FMEA and Lean Manufacturing appear frequently on PSS Engineering literature (CAVALIERI; PEZZOTTA, 2012; AURICH; MANNWEILER; SCHWEITZER, 2010; SASSANELLI et al., 2015). On the other hand, methods imported from related fields as Service Blueprint, Gap Analysis and even Object-Oriented Modeling, has also been explored by PSS designers (AURICH; MANNWEILER; SCHWEITZER, 2010).

Nevertheless, it seems like there is a common agreement in Service Engineering: product-service life-cycle is a central idea on PSS design (SAKAO; MIZUYAMA, 2014; MEIER; ROY; SELIGER, 2010; AURICH; MANNWEILER; 
SCHWEITZER, 2010). In a product engineering situation, conceptualization, development, delivery and product usage could be disengaged from it service part, fragmenting for example, marketing, sales and maintenance. The only concern on product life-cycle was related to the product discard and environmental issues. However, for a PSS design context, the whole life-cycle gains a strategical position as the same time it creates new challenges for operation and manufacturing. Authors as Aurich, J. and Sakao, T. are developing approaches encompassing the whole PSS life cycle on the design process.

On the other hand, new developments on PSS design are moving towards a CAD (Computer-aided Design) systems for product-service systems (SAKAO; MIZUYAMA, 2014; CAVALIERI; PEZZOTTA, 2012).

\subsubsection{Computer Science Service Design}

From a Service Design perspective in computer science, the IBM's Service Science, Management and Engineering (SSME) initiative in 2004 was a important millestone to the whole service science field (IBM, 2008).

In fact, the research initiatives started before that, during the late 90s. It was related to e-services and the provision of service over electronic networks such as the Internet (MOUSSA; TOUZANI, 2010):

"The emergence of IT and especially the Internet during the late 1990s as an important business tool (i.e., e-commerce) and its potentials for creating new business models, radical new approaches in service delivery (e.g., IT-based self-service technology such as on-line ticketing and reservation, on-line bank account access, on-line package tracking, and so forth), and new ways of relating to customers (i.e., e-Customer Relationship Management) have prompted service researchers to study IT infusion into services." 
Therefore, information technology first infusion with services had an Internet perspective from web services, e-commerces until self-service technologies (SST). However, those efforts led to a transversal perception of the need of information services applied to a business structure that supports consumer needs thought services:

"In the IT context, services-oriented systems address the fusion of business processes and technologies by building innovative bridges or autonomous, implementation-independent interfaces from business processes to software, data, and technology service. (IBM, 2008)"

The rise of service-oriented architectures (SOA), as an approach for designing and developing information services (MOHAMMADI; MUKHTAR, 2013), pushed IT practices closer to the enterprise business and governance activities. Hurwitz, J. et al. (HURWITZ et al., 2007) define SOA as:

"A service oriented architecture (SOA) is an architecture for building business applications as a set of loosely coupled black-box components orchestrated to deliver a well-defined level of service by linking together business processes."

Even if SOA proposal comes before IBM's SSME, it is after this initiative that researchers started to examine the profound differences between information systems (encompassing information services) and Information Service Systems (RALYTÉ; KHADRAOUi; LÉONARD, 2015). For Ralyté, J. et al, in traditional information system design (including information services as one of its components) people are considered independent systems interacting with the information system, not supporting value co-creation. Further more, in their analysis, information system are static pieces of software that remains closed to a more 
dynamic evolution. In opposition, information service systems proposes a new way to structure information based on modularity, agility, and interoperability.

From a design process perspective, the majority of approaches are inherited form Information Systems Design methods using specially architectures as SOA (RALYTÉ; KHADRAOUI; LÉONARD, 2015; MOHAMMADI; MUKHTAR, 2013; KEITH; DEMIRKAN; GOUL, 2013). A recent discussion addresses even the distinction between traditional plan-driven methodologies (i.e. waterfall) and agile software development (ASD) methodologies (e.g. XP, SCRUM, etc.) to reach a hybrid methodology based on concepts from the service-oriented paradigm (KEITH; DEMIRKAN; GOUL, 2013).

Therefore, the challenge for Computer science and information science in Service Design consists in propose an approach to create information service systems (composed of people, hardware and software) that proactively respond to strategy changes related to different client behavior aiming a value co-creation.

\subsubsection{Service Design approaches comparison}

Table 3 shows how each of the discussed Service Design approaches are able to achieve the reference service life-cycle characteristics and its ability to achieve the service definition characteristics introduced on section 2.1.2.

In fact, as each approach has different degrees of formalism and different nomenclatures, this analysis obviously has limitations. Besides, aiming a field comparative analysis, the final relation that is compared is between a collection of frameworks, methods and tools with references service and service design characteristics.

The first set of analysis is a related to the reference Service Life-cycle (see Fig. 2) and the degree of application from each field's "collections of approaches" 
Table 3: Reference Services and Service Life-cycle characteristics vs Service Design Approach fields

\begin{tabular}{lcccc}
\hline $\begin{array}{l}\text { Reference design char- } \\
\text { acteristics }\end{array}$ & \multicolumn{5}{c}{ Service Design Approach Filed } \\
\hline \multicolumn{5}{c}{ Design Characteristics from Service Life-cycle } \\
\hline $\begin{array}{l}\text { Reference Cycle } \\
\text { Identification }\end{array}$ & - & - & $(\mathrm{X})$ & $\mathrm{X}$ \\
\hline Evolution Cycle & - & - & - & - \\
\hline Realization & - & $(\mathrm{X})$ & $\mathrm{X}$ & $\mathrm{X}$ \\
\hline Satisfaction Cycle & - & $\mathrm{X}$ & $\mathrm{X}$ & $\mathrm{X}$ \\
\hline Innovation & $\mathrm{X}$ & - & $\mathrm{X}$ & $\mathrm{X}$ \\
\hline \multicolumn{1}{c}{ Design Characteristics that support service characteristics } & \\
\hline Co-creation & $(\mathrm{X})$ & $(\mathrm{X})$ & $(\mathrm{X})$ & $(\mathrm{X})$ \\
\hline Co-production & - & $\mathrm{X}$ & $(\mathrm{X})$ & $(\mathrm{X})$ \\
\hline Co-design & $\mathrm{X}$ & - & - & $(\mathrm{X})$ \\
\hline \multicolumn{1}{c}{ Design Characteristics } & enabled by semi-formal and formal techniques \\
\hline Process/Plan & - & $(\mathrm{X})$ & $\mathrm{X}$ & $\mathrm{X}$ \\
\hline Stakeholders & $(\mathrm{X})$ & - & - & - \\
\hline Resources & - & $(\mathrm{X})$ & $\mathrm{X}$ & $(\mathrm{X})$ \\
\hline Value/Benefit & - & $\mathrm{X}$ & - & $(\mathrm{X})$ \\
\hline
\end{tabular}

to each reference phase. The symbols meaning: "-", poor or zero, "(X)" partial and "X" acceptable degree of application.

As a second set of analysis is investigated how each service design approach takes into account the three design characteristics introduced on section 2.1.2: Co-creation, Co-production and Co-design. In fact, this comparative analyze took into account the degree of importance of each one of the field's "collections of approaches" give to each one of the characteristics.

The last set of characteristics used for the analyze is related to the degree of formalism of the modeling and execution techniques, from each field, that achieves the design of the service definition basic characteristics as: process/plan, stakeholders (providers/consumer), resources (all types) and value/benefit. In fact, what is analyzed is the power of modeling/execution of each collection techniques to design an adaptable process, customer and provider behavior, informational 
and physical resources and measurable value/benefit to value-creation.

The most important conclusions of this analysis can be summarized on:

- Dominance of Engineering and Computer Science on Service Life-cycle Approaches: In terms of explicit and formal approaches for service lifecycle both Engineering and Computer Science presents better frameworks, method and tools.

- Gaps on Identification and Innovation transition phases: Even if some approaches present a Reference Cycle, the identification transition phase, as an early service design phase, have no clear process from a system-as-is to a system-to-be. In terms of Innovation transition phase, the Marketing field present better tools and techniques to grab new opportunities, however, its lack on Evolution Cycle and Realization leave those opportunities as conceptual propositions.

- Computer Science satisfactory approach for the Reference Cycle: Even if a system-as-is, in terms of context and domain modeling phase, presents difficult in terms of modeling, the computer science have been improving since Model-Driven Engineering proposition took place. Meta-models, ontologies and computer logic are part of this modeling improvement.

- Computer Science seems to reach all Co's characteristics: In terms of cocreation, Computer Science and the others fields reach some level using different, and sometimes complementary strategies to measure and adapt value creation. In terms of co-production, SOA structure creates the basis for informational services to co-produce. At lest, modeling languages based on diagrams and Requirement Engineering methods have been creating a important base for co-design. 
- Marketing Co-design and Operation Co-production satisfy the characteristics: The Marketing co-design is based on visual frameworks and design experiences workshops in order to improve participatory design. On the other hand Operation Co-production is based on business and parts agreements negotiation process that can structure the co-production at a business service level, not just informational as in computer science.

- Just Marketing has an approach for Stakeholder's modeling: A more complex and complete model of stakeholders involved on the service system is just seem on Marketing field. Cognition models, Personas and User Journey explore better their behavior and predict its aims and goals. Unfortunately, the lack of formalism and the missing Identification and Evolution phases on a whole design, for the Marketing field, can just transport this modeling effort to a set of business insights.

- Just Engineering has an satisfactory approach for Resources modeling: Operation Management resource modeling approach stays on a business process level while Computer Science has limitations on modeling informational entities. The Engineering approach, in terms of system engineering, can model agents, informational entities and machines as resources for the service system.

- Just Operation has an satisfactory approach for Value/Benefit measurement: The field evolved value perceptions formulas and variables to measure quality.

Therefore, an strategy that seems more effective to Service Design, according to the analyze, should be based on Engineering and Computer Science approaches. Their complementarity with some specific development efforts could create a service design process that respects the whole life-cycle and seeks for all 
service characteristics.

\subsection{Requirement Engineering and Service Systems Design}

The Requirement Engineering (RE) field have been growing since the last decades. Initially it started as a branch of study in System Engineering Design, focusing on a more systematic and disciplined initial phase (YU, 2001). However, RE has been mobilizing researchers in such a way that today it gained its own rights as a research field. Therefore, it culminated is an almost clear separation between two different phases in systems development: requirement engineering phase followed by design phase (LAMSWEERDE, 2008).

In fact, for the Service Design, our hypotheses is that key issues are in the early phase of design, i.e. on the overlapping of frameworks, methods and tools from Requirement Engineering and Design Engineering. On fig. 3, the life-cycle is explored on a detailed view from each cycle and it interaction with the world.

Therefore, Requirement Engineering is centered on the activity of modeling system-as-is and identifying on it needs and opportunities that will propose a first system-to-be. It is composed by the following phases:

- Eliciting (System-as-is): It is a phase where the system designer explores the world in order to gather all the information needed to model the context as a system-as-is. It can be made by techniques such as interviews with stakeholders, documentation analysis or event a co-modeling process with the stakeholders. It aims is a collection of unstructured data that will be structured on a first system-as-is.

- Modeling (System-as-is): Is the process of structuring the data gathered on eliciting phase on a System-as-is model. 


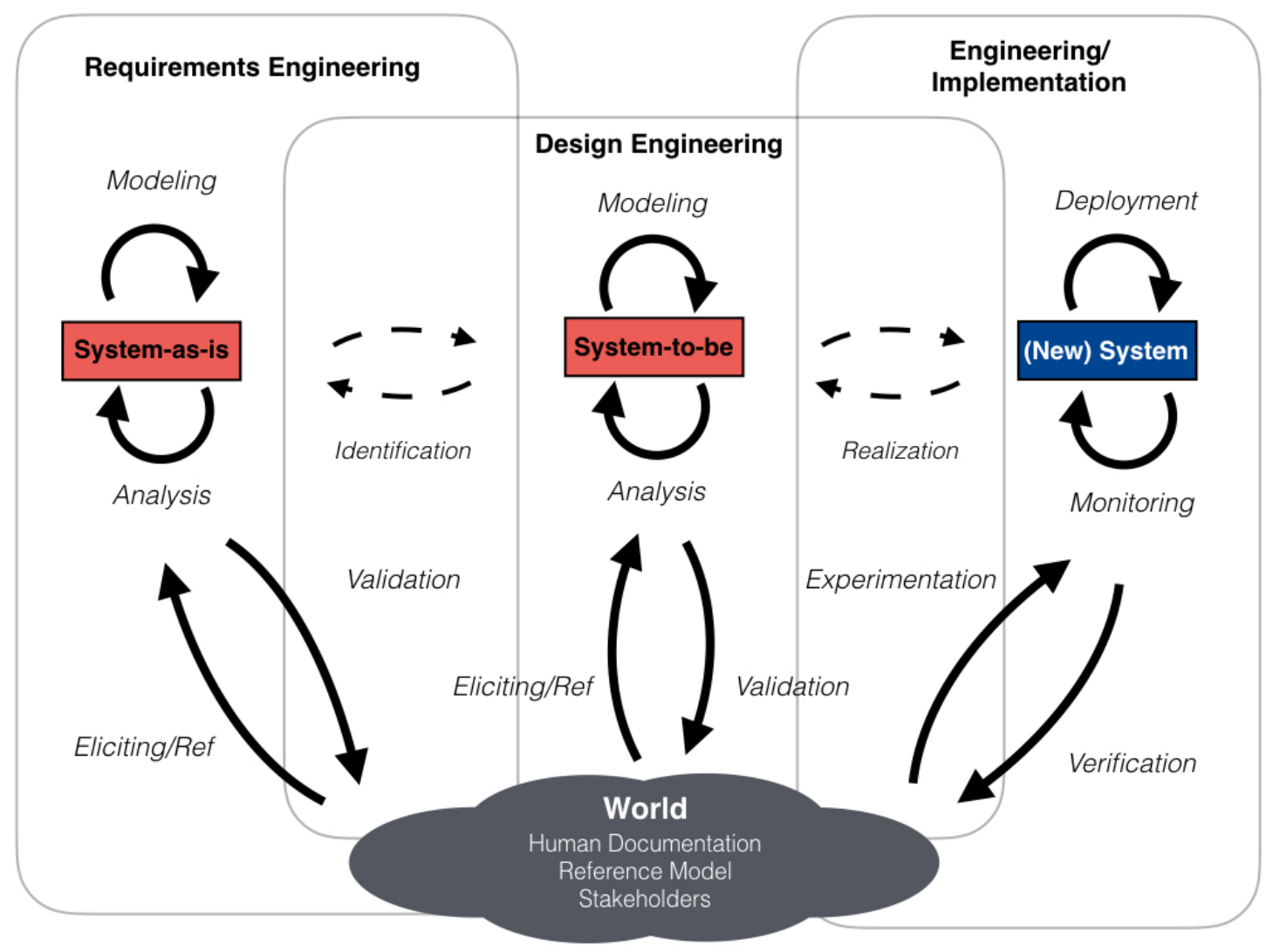

Figure 3: Requirement Engineering and Service Design Engineering. Figure created by author. 
- Analysis (System-as-is): Is the phase that checks for inconsistencies and completeness on system-as-is model.

- Validation (System-as-is): Is the process of validation of the system-as-is model that can be an input of new data if the model did not converged on a acceptable model with the stakeholders.

- Identification (System-as-is to System-to-be): It is the phase of identifying needs and opportunities of the system-as-is and proposing a first set of service structure solutions that could attend those needs and opportunities.

On the other hand, Design Engineering is centered on the system-to-be model and Evolution Cycle, that is composed by the following phases:

- Eliciting (System-to-be): It is a phase where the system designer explores the world, based on the needs identification and the first solution structure proposed, to gather more information about possible expectation missed from the first analysis made during requirement engineering.

- Modeling (System-to-be): It is a modeling phase of the service solution, its structure and behavior that attends the needs and opportunities identified on the previous phases.

- Analysis (System-to-be): Is the phase that checks for inconsistencies and completeness on system-to-be model.

- Validation (System-to-be): Is the process of validation of the system-tobe model in the world checking for incompleteness or unknowing service situations.

The transition phase Realization and more detail exploration on Satisfaction cycle will not be part of the following analysis. As we understand that key issues 
are on early phases of Design we will concentrate on overlap of Requirement Engineering and Design Engineering.

\subsubsection{Requirement Engineering Evolution}

By the mid-1980s requirements engineering became recognized as an newborn discipline in its own right (ZAVE; YEH, 1981; JACKSON, 1983; LAMSWEERDE, 2008). It first concern was the need to focus requirement engineering term in the "relationships between systems and their environments, rather than stating requirements only in terms of the systems" (ERIC, 2011).

In fact, RE stands out the importance of "real-world" understanding for a good system design, i.e. the environment, context and the specific domain were the system will operate.

Since the early 1990s RE has had its own conferences and a growing literature (LAMSWEERDE, 2008; NUSEIBEH; EASTERBROOK, 2000). Formal requirements modeling languages were developed, several approaches to address business goals were created and a deeper development on higher goals as a requirement engineering orientation was stablished (ERIC, 2011).

Lamsweerd defines RE as following:

"It embraces a large spectrum of activities, from discovering the needs and purposes of stakeholders - everyone who would be in any substantial way touched by the proposed system - and resolving the inevitable conflicts, to devising detailed human and computer processes to satisfy the identified system requirements. Requirements engineering must therefore include investigation and analysis of the world in which the requirements have their meaning, because it is in, and through, that world that the computer, executing the developed 
software, must bring about the desired effects."

In fact, that first phase of investigation and analysis related to the discover of the needs and purpose of stakeholders, became the central aspect on the field. Since that, specially from late 90 s to mid-00's, several approaches were developed to address two important problems: (i) ambiguity and imprecision and (ii) management of the large amount of knowledge that was covered in informal or semiformal requirements (ERIC, 2011).

Therefore, important advances were made in three areas: (i) specification of the different types of requirements, (ii) detailing of each requirements engineering's phases and (iii) definition of modeling languages for requirement processes.

The specification of different types of requirements allows better forms of analysis using logical assumptions to check consistence. Kontonya and Sommerville, in their seminal Requirement book (KONTONYA; SOMMERVILLE, 2002) defined requirements in four types: (i) how the system should behave, (ii) application domain information, (iii) constraints on the system's operation, or (iv) specifications of a system property or attribute. Another very used classification split requirements in functional requirements and non-function requirements. Functional requirements being the capabilities of the future system while non-funcional being constraints or quality requirements (as performance requirements, maintainability requirements, safety requirements, reliability requirements and etc.) (SAWYER; KONTONYA, 2001). Others authors still organize all possibles statements about the system and its environment in Requirements, Domain Properties, Assumption and Definitions (LAMSWEERDE, 2008; JURETA et al., 2014).

The detailing of each requirements engineer's phase allows an specialization of the techniques in each context at the same time that creates transition gates that 
points advances and convergences of RE process. There is no consensus about the phases and process of RE, however all different approaches keeps closed to the the following phase framework given by Kontonya (SAWYER; KONTONYA, 2001): acquisition (or elicitation), analysis, specification, validation and management of requirements. Some authors add even that the RE process can be viewed as an iteration on successive increments according to a spiral model (KONTONYA; SOMMerville, 2002). From a different perspective, Pohl proposed a three dimensional framework to understand the process evolutions. Pohl states that Requirements Engineering process navigates from a low state of specification, representation and agreement to a high state of those three dimensions (TUUNANEN, 2003; POHL; ULFAT-BUNYADI, 2013).

Finally, the definition of modeling languages for requirement processes allows both a more formal process of analysis and the genesis of computer modeling tools to support the designer. During 90's as 00's, several modeling languages and approaches were developed and tested in RE. Semiformal models such as Structured Analysis and Design Technique (SADT) (ROSS, 1977) (more commonly referred to as IDEF0 in business process context), Data Flow Diagrams (DEMARCO, 2002) and Unified Modeling Language (UML) ((OMG), 2009) were used in RE developments using decomposition as the main abstraction mechanism for incrementally revealing details (ERIC, 2011). On the other hand, languages as Requirements Model Language (RML) (GREENSPAN; BORGIDA; MYLOPOULOS, 1986) and Telos (MYLOPOULOS et al., 1990) were proposed in Requirement engineering in other to recognize assertions as an ontological category on a par with activities and entities, however they do not support the link between those assertions and the systems activity, leaving an important gap.

From mid-2000, Goal-Oriented Requirement Engineering (GORE) emerged as approach very consistent to RE (LIU; YU, 2004). Adding the concepts of 
goals and softgoals, that could be understood as a high-level stakeholder objectives (YU, 1997), it opened a new level of analysis capturing the "why" dimensions of the stakeholders. The incorporation of explicit goal representations in requirement models provides a criterion for requirements completeness, i.e., the requirements can be judged as complete if they are sufficient to establish the goals that they are refining (LIU; YU, 2004).

From a model language perspective, several GORE frameworks have been developed. All of them, NFR framework (CHUNG et al., 2012), KAOS (LAMSWEERDE, 2001), and i* (YU, 2001), emphasize a model that decompose the goals into fine-grained requirements assignable to the system to be designed.

In a even more recent time, several authors are addressing the requirements evolution problem using an adaptive perspective for dealing with changes and its unpredictable characteristics. Even if those problems have been addressed by traceability models or more iterative methods (LAMSWEERDE, 2008), Jureta re-framed the requirement problem and proposed a formal approach to manage the design and system adaptation (ERNST et al., 2014; JURETA et al., 2014).

\subsubsection{SOMF, Softdiss and Tropos as Service Engineering Design Ap- proaches}

In terms of Design Engineering Approaches that encompass Requirement Engineering phases and that could be a groundwork for a Service Engineering Design approach, it was collected three main design approaches for analysis: (i) SOMF (Service-Oriented Modeling Framework) (BELL, 2008), (ii) SoftDiss (Service Ori-

ented Framework to the Design of Information Service System) (OLIVEIRA, 2013) and Tropos (HORKOFF; YU, 2012).

According to Michael Bell (2008), SOMF is a software development method that presents an anthropomorphic and holistic modeling language, applicable to 
the different levels of abstraction required by the development life-cycle steps, from the business vision to the Realization of the software design. SOMF offers two lines of action during the software development process, one based on what should be made and other on how to make it, both driven by a common service oriented modeling language.

This framework is directed to the design of (information management) software systems to service.

On the other hand, SoftDiss is defined as a framework for eliciting, documenting and analyzing service information systems (SIS) requirements. SoftDiss claim to serve SIS developers in the task of modeling and designing until it reaches a formal specification of the target system (system of interest).

The main goal is the realization of a chain of services that meets distinct viewpoints and leads to a formal specification of the ISS.

Among the basic assumptions, SoftDiss assumes that requirements are divided into business process $(\mathrm{BP})$ and basic requirements, covering all distinct viewpoints. The requirements are arranged to compose models of the service system in different levels of abstraction and in different levels of formalization ranging from informal specifications in a semi-formal stage, until a formal requirement specification in a more formal language, such as SysML. BP are strictly linked to stakeholders, while others may meet the requirements viewpoints of various classes of agents, including users, managers and son on.

At least, Tropos is an approach intended to support all analysis and design activities in the software development process, from application domain analysis down to the system implementation. In particular, Tropos rests on the idea of building a model of the system-to-be and its environment, that is incrementally refined and extended, providing a common interface to various software develop- 
ment activities, as well as a basis for documentation and evolution of the software.

Tropos is based on GORE methodologies as $i^{*}$ and KAOS that guides the modeling evolution from early requirements phases until the software implementation using agent-orientation language.

\subsubsection{Service Engineering Design Attributes}

In order to build a comparative analysis it was chosen some attributes relating to a reference Service Engineering design approach. Table 4 presents the attributes and the degree of application from each of service engineering design approaches previous presented.

The attributes were organized on three sets. The first one, concentrating attributes related to design practical support: a well-defined Design Discipline, a framework or architecture that's support design and a Design modeling tool. The second set of attributes is related to Design Engineering characteristics as Traceability and Model-Driven orientation ((OMG), 2009; KENT, 2002). The last set of attributes is related to the Service Engineering characteristics introduced on previous section.

In terms of practical support, both SOMF and Tropos satisfies all three listed attributes. In other words, both proposes a design discipline, defines a framework/architecture to guide the design and are supported by a single software design tool (Enterprise Architect for SOMF and TAOM4E for Tropos).

Even if SoftDiss is supported by a design discipline and a framework, it partially satisfy the Design tool attribute, as it does not have a single design software platform but its supported by a series of combined tools.

For Design Engineering variables, only Tropos satisfy traceability, from the point of view that it software platform traces the modeling from requirement 
Table 4: Attributes for a Reference Services Engineering Design vs Service Engineering Design Approaches

\begin{tabular}{|c|c|c|}
\hline Attributes & \multicolumn{2}{|c|}{ Service Engineering Design Approaches } \\
\hline & SOMF SoftDiss & Tropos \\
\hline \multicolumn{3}{|c|}{ Service Designing Practical Support } \\
\hline Design Discipline & $\mathrm{X}$ & $\mathrm{X}$ \\
\hline Framework/Architecture & $\mathrm{X}$ & $\mathrm{X}$ \\
\hline Design Tool & $(\mathrm{X})$ & $\mathrm{X}$ \\
\hline \multicolumn{3}{|c|}{ Design Engineering Variables } \\
\hline Traceability & $(\mathrm{X})$ & $\mathrm{X}$ \\
\hline Model-Driven & $\mathrm{X}$ & $\mathrm{X}$ \\
\hline \multicolumn{3}{|c|}{ Service Engineering Design Characteristics } \\
\hline Eliciting & $(\mathrm{X})$ & $(\mathrm{X})$ \\
\hline Modeling & $(\mathrm{X})$ & $\mathrm{X}$ \\
\hline Analysis & $(\mathrm{X})$ & $\mathrm{X}$ \\
\hline Verification & $(\mathrm{X})$ & $(\mathrm{X})$ \\
\hline System-as-is/to-be & $(\mathrm{X})$ & $\mathrm{X}$ \\
\hline
\end{tabular}

to implementation. In fact, Tropos platform TAOM4E for Eclipse, has it entire design cycle on a single design tool, allowing traceability from the first early requirements model to its java implementations classes. However, SOMF and Softdiss presents partial application of traceability using Enterprise architect design platform. Both approaches present a more open modeling structure leading to a less restricted modeling vocabulary that difficult a complete treaceability.

On the other hand, just SOFM do not apply for Model-Driven architecture, despite it several diagrams relationships. SoftDiss and Tropos design approach, on the contrary, follows a series of defined modeling transformations which has to converge firstly before advance to the next modeling phase.

At least, for Service Engineering Design characteristics, both SoftDiss and Tropos presents partial propositions for the Eliciting and Verification phases, as they do not clearly indicates eliciting/verification methods with the stakeholders, but provide requirement and early requirement modeling elements to support those phases. Also, both present a satisfactory Modeling and Analysis phases 
as they apply for languages and formal analysis methods such as SysML for SoftSiss and KAOS for Tropos. Whats stands out between both approaches is the exception on the last characteristic which Tropos presents as clear modeling proposition, on its design life-cycle, of System-as-is and System-to-be models.

Therefore, in terms of Service Engineering Design, SoftDiss and Tropos approaches are almost equivalent in comparison with Service Engineering Design Reference. Both could be used to establish foundation's elements for the design of service systems. As they basically came from Computer Science approach, there is still a need for a broader Service Design perspective.

\subsection{Service Systems applied to Manufacturing}

Service Engineering, from a manufacturing viewpoint, is more concerned to the engineering solution, and how it satisfies customers needs, than the infrastructure to produce it.

In general, the manufacturing process, over the last century, had been essentially a production chain transformation process from suppliers raw materials inputs until distribution to the final consumer (See Fig. 4).

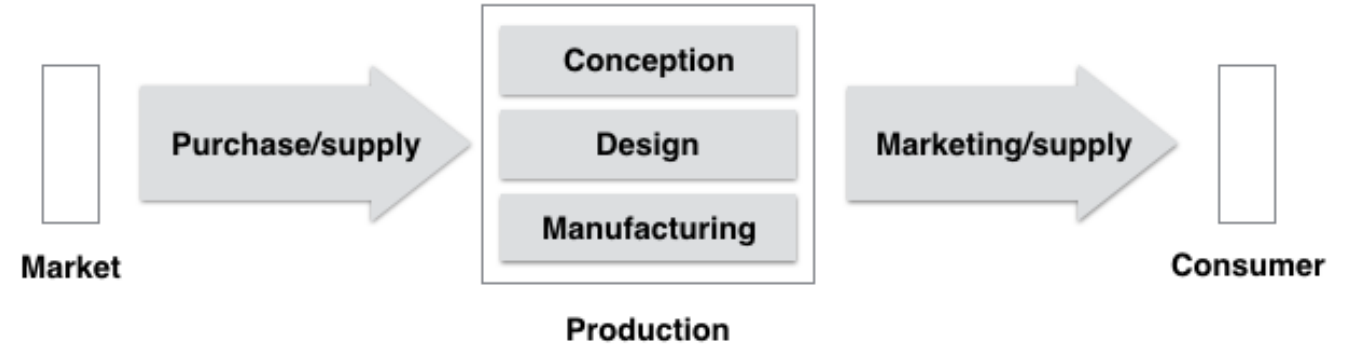

Figure 4: Manufacturing as pull production 
This current settled rigid structure of knowledge, management and production based on a chain that idealize functions and creates artifacts, for the service engineering researchers, is about to change to a new way of design e and producing oriented now to the "receiver's state change" (SAKAO et al., 2009).

Service engineering researchers normally analyze the changes on manufacturing process through its outputs. Product-service systems (PSS) are an extension of the traditional manufacturing output, adding a service layer that seems to adapt better to value creation with final customer. On the other hand, Sampson's customer-supplier paradigm (SAMPSON, 2007; PINHANEZ, 2008) analyses any production process in terms of its inputs, stating that the service systems are process with intensive customer inputs. That leads to a new interpretation of the production flow in terms of an exchange process between costumer and manufacturer, including even the product as a shared resource to service deliver. In fact, that logic extend to all production chain and modify the exchange process through the whole chain, including customers and suppliers on that process (see Fig. 5).

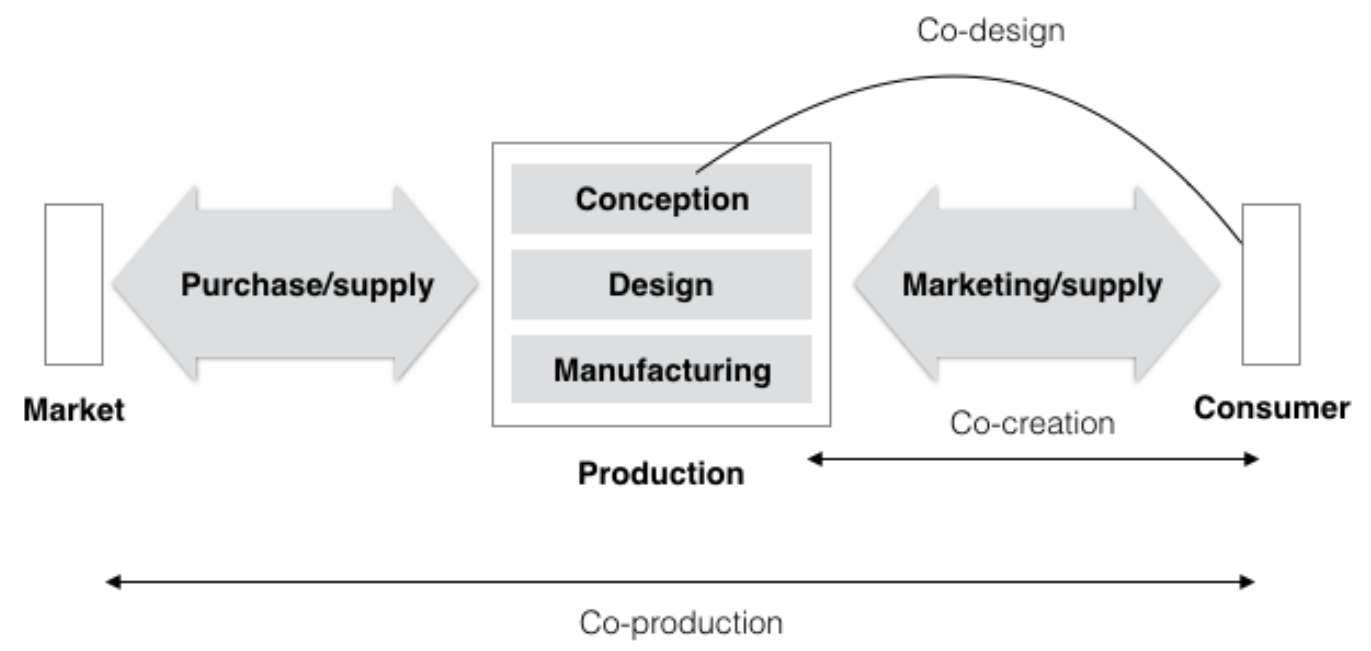

Figure 5: Service Orientation on Manufacturing 
Therefore, Service Systems through manufacturing perspective launch a new orientation over the three services systems' characteristics: (value) co-creation, co-production and co-design. As shown in Figure 5 a service manufacturing production strategy include the following characteristics: i) suppose complete integration with suppliers, composing a co-production process (which also involves the user); ii) work with user viewpoints in co-design, to adjust requirements or to even create new products/services; iii) fits the need to include the proper issues to enhance value co-creation with the costumer.

Generalizing and expanding Sampson's reasoning, a service manufacturing could be seen as a transformation process that includes an intensive exchange process between suppliers, manufacturer and final customer. That intensive exchange process include resources that can be exchange or just shared during the process. Resources in the exchange process can be goods, products, facilities, information, knowledge and even labor.

Therefore, instead of a series of production unities coordinated by manufacturer, the service manufacturing advances toward a set of production unites that collaborates sharing intensively its resources.

\subsubsection{Infrastructure supporting a change toward a Service Manufac- ture}

During the last decades, practitioners and researchers experienced an evolution on production systems. Driven by new intelligent machines, faster network architectures and multiple ICT devices interconnected through internet, industry and production are about to face radical transformations. A substantial increase of operational effectiveness on the production value chain is pointing to what some authors call the 4th industrial revolution (WAHLSTER, 2012; BLANCHET et al., 2014; EVANS; ANNUNZIATA, 2012). 
Named by German authors as Industry 4.0 (BLANCHET et al., 2014) and, similarly, called Industrial Internet (EVANS; ANNUNZIATA, 2012) in USA, a next generation of manufacturing systems is envisioned as an infusion of concepts including Internet of Things, Cyber-physical Production Systems, Internet of Services and Smart Factories (HERMANN; PENTEK; OTTO, 2015).

They state that systems production and processes are forming a new sophisticated network arrangement supported by internet and combined with intelligent machines. That revolution is guiding manufacturing to reach the concept of smart (virtual) factories producing smart products.

Those technologies brings more freedom and flexibility into the production process, growing the focus on innovation to enhance quality and address customer individual needs.

Besides that, new protocols, planing and control theory towards collaborative work system have been developed over the past decade (NOF et al., 2015). Productive activities based on shared resources and collaboration supported by computer and communication protocols are the basis of Nof's proposition for collaborative e-work systems.

Based on collaboration between artificial and human agents, and powered by ICT devices, collaborative e-work systems is a framework for design, engineering and control of a network of intelligent and autonomous agents that collaborate together to achieve a goal (NOF et al., 2015; SILVA; NOF, 2015)

The proposal of collaborative e-work systems appears as as important concept that supports Industry 4.0 and that could form a basic framework to produce product-service systems (PSS), the main design object of Service Engineering.

Therefore, the combination of Service Engineering with the platforms and infrastructure prepared for Industry 4.0 can be very fruitful. While Industry 
4.0 can propose a flexible and adaptive platform for service manufacturing coproduction, the Service Engineering can propose new configurations to transform smart products into product-service offerings, customized and adaptable to a wide range of customers (DUTRA; SILVA, 2017. In pressa).

Our main hypotheses is that there is a latent coalition between Service Engineering and Industry 4.0 through the relationship between collaborative e-Manufacturing (e-work) and Service Systems co-production model (DUTRA; SILVA, 2017. In pressb).

To support the transformation of the production process into product-service offers we propose the use of a design discipline using the product-service architecture (PSA) proposed by Silva and Nof (SILVA; NOF, 2015).

PSA's perspective is attached to physical cyber-physical System (CPS) agents to form a distributed architecture and derive a manufacturing service arrangement that is flexible and adaptive. In the next chapter we will present the ProductService Architecture (PSA) and the service design discipline proposed to address PSA modeling and design. 


\section{PROPOSAL}

\subsection{Product-service Architecture}

The Product-Service Architecture (or just PSA) was proposed first by (SILVA; NOF, 2015) and has been developed since then by Service Design research group at Design Lab in Escola Politecnica da USP. PSA is a distributed architecture where a service provider is defined as an open set of production unities (which could deliver products, services, or even product/services) that could be independent or commercially connected to the service provider corporation.

This architecture aims to answer the need for a service-oriented approach to product-based organizations experiencing a closer relationship between them and the customer, pushing its internal design to achieve new solutions that meet the customer's needs. This change, flips the primary focus on the function of a product and its production process, to a focus on a desired state of the final receiver and the monitoring of the delivering. Therefore, product's functions and its production process gain a new level of flexibility, which is the capacity of adapting to maximize the value co-creation with final customer.

The basic element of the PSA, the " production unit" (pu), is defined as an arrangement of persons and machines capable to deliver a product, a service or a product/service. Eventually this pu could have only people or just machines. The production unit, differently from a classical production unit, is not specialized on a sequence of tasks that transform an specific input material into an specific out- 
put. It understands and adapt the hole production process to answer to different kind of demanding inputs and propose new outputs (eventually innovative ones) (DUTRA; SILVA, 2017. In pressb).

Suppose now that there is a general (finite) value production process that interacts in a specific moment with one or more pu's, and that in the final state delivers a new product, service or product/server. We would call this process a service provider and the generic pu's, its components, sub-services. Once the final consumer is identified it is possible to plan the pu's arrangements, actions, inputs and outputs to deliver the proper product/service. Therefore, the service provider has also the need to deliver a final state that ensures the value co-creation offered by the service, product or product/service.

The overall architecture is what we call a PSA Architecture. Comparing with the basic consumer-provider interaction proposed in (QIU, 2014) (chapter 1, pg. 3) this architecture provides an extended relationship between a PSA's arrangement and a final consumer as depicted in Fig. 6. This figure shows how a PSA architecture can couple with a final user to provide product/service embedded in its shared resources.

The PSA is represented by a cloud of production unities (that can be also sub-services) that should form a production arrangement providing a product/services to final consumer. During consumer engagement with the system, the provider interface has to dialogue with the costumer in order to identify his intention/expectation of the service system. From that, the provider has to create a service plan with the production units that should be implemented by a workflow. During the service execution, several consumer touch-points can happen. Those touch-points allow for a value satisfaction measurement and, if necessary, re-plan the production arrangement (DUTRA; SILVA, 2017. In pressb).

Therefore, the main elements of the architecture, (Fig. 7) are: (i) cloud of pro- 


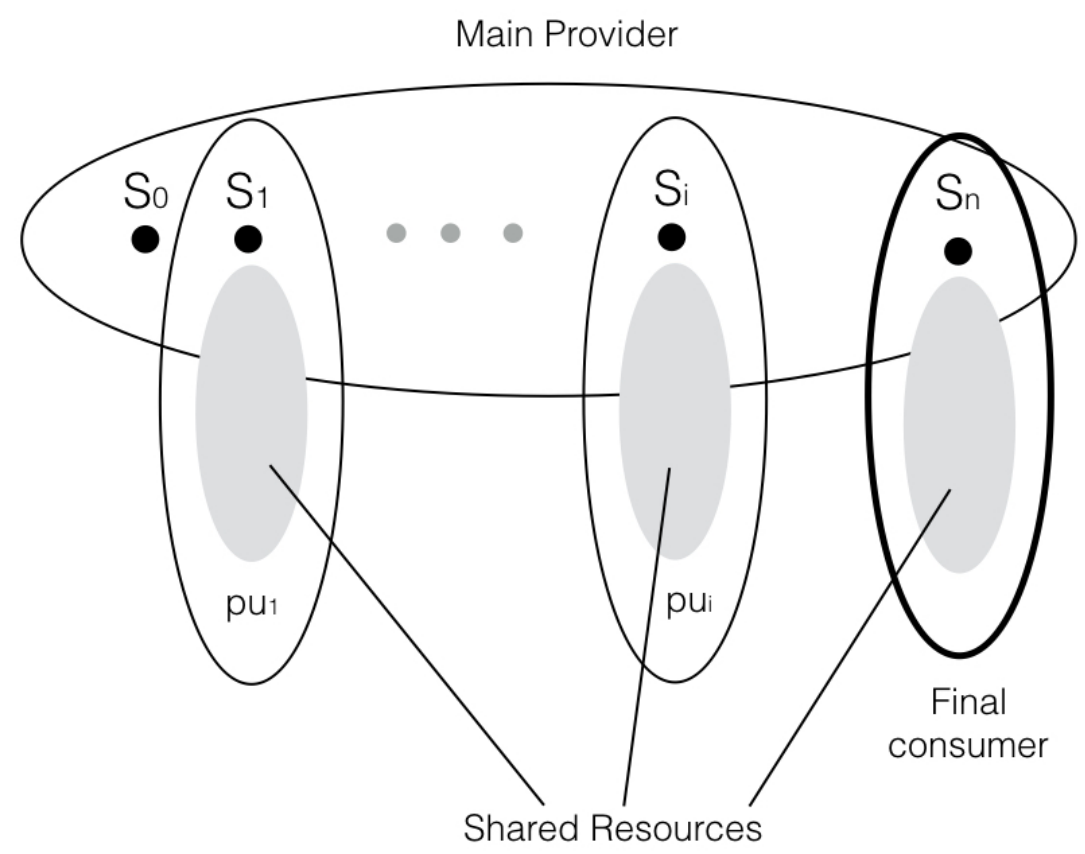

Figure 6: Production unities in a Service Provider combination. Adapted from (SILVA, 2014).

duction unities, (ii) a workflow and protocol management module, (iii) a service planner module, (iv) an intention prediction and value co-creation satisfaction module, and (v) service user interface.

To reach value co-creation it is necessary to predict and measure service relationship with customer. An interface that capture some client inputs to feed a system that predicts clients intentions related to a combinations of services planned (scheduled) or to provide the deliverable product/service. A formal workflow representation defines the resource sharing and the exchange of information between sub-services. Plan problem execution and its interaction with the context should result in a process that delivers service, information, and resource items. As the plan execution, a satisfaction module should check and adapt the plan if value co-creation do not reach a certain level. This feature, called value co-creation supervisor is a key issue in the architecture, and follow the same approach used 
in a post-design proposal for artificial intelligence planning (VAQUERO et al., 2007; VAQUERO; SILVA, 2005).

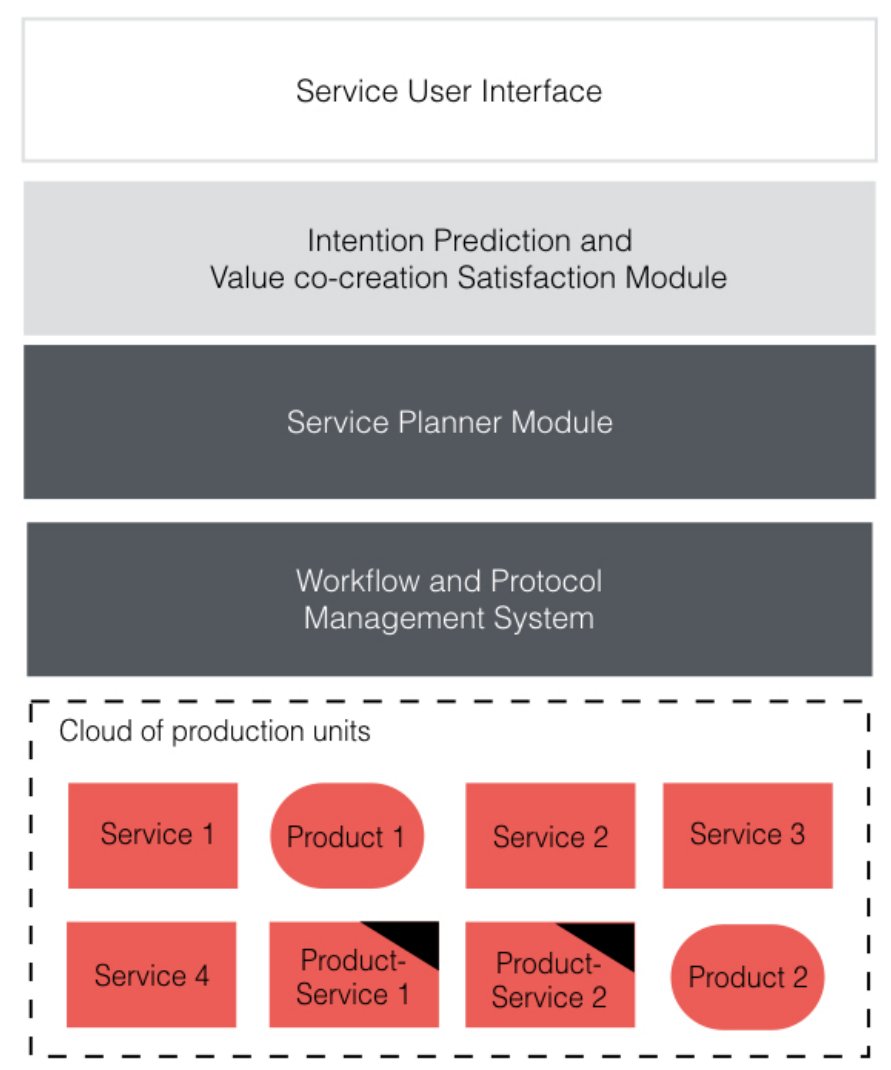

Figure 7: Product-Service Architecture. Figure created by author.

Production units could be commercially connected or absolutely independent of the service provider corporation. Some benefits should be generated throughout the distributed process of production rewarding somehow all participants, be them clients or providers. That is what in service science is called value coproduction. However, what should be stressed here is that all benefits generated in the production process converge to a set associated to the relationship between the overall provider (the stakeholder on the whole manufacturing service network) and the final costumer. Also, it should be noticed that all relations associated to the final costumer would carry more than just a transference of property (OLIVEIRA; SILVA, 2015). 
Therefore, PSA proposes a distributed architecture to product/service production arrangements based on a clouded system of systems. This architecture could form a base to generate different production arrangements including several adaptations meant to fit a target product/service. This match the service-logic applied to production systems where the structure of elements that compose the value co-creation network deal with intentions and expectations from the main provider as well as from expectations from the final costumer.

PSA architecture is an ongoing research on Design Lab of Escola Politecnica da USP, integrating multiples efforts of researchers in Design, Formal Modeling, Requirements Engineering, Service Science and Automated Planning and Scheduling using AI techniques. However, it already presents a promising proposal to support the creation of service systems that are strongly based on modern manufacturing processes.

\subsection{PSA Design Discipline}

The PSA Design Discipline is a iterative set of sub-processes of the reference service life-cycle introduced on chapter 2. Each step of the discipline can have the customer participation (sometimes this is demanding) and allows the possibility of return to a former step (Fig. 8).

It is formed by two stages, the Requirements and the Design stage with an overlapped phase that represents the identification of needs and opportunities to propose a first conception of the production process to be implemented. In fact, the design discipline can be seen as a series of transformations from a systemas-is, to the system-to-be. The system-as-is is a model (or a combination of models) representing what exists before the solution is built. The system-to-be is a model (or a combination of models) representing the system as it should 
be when the solution were built. The new system, from the life-cycle point of view, derives from the implemented solution that meets costumer needs uncovered during design phase.

From the system-as-is to a system-to-be there are seven phases that transform and evolve the solution:

- Eliciting: It is the phase where enough information is gathered to understand the context and represent the system-as-is. It starts as a non-formal process where stakeholders are identified with their respective viewpoints, to established stakeholder's needs and desires.

- Modeling (system-as-is): It is a phase where the information gathered on eliciting phase are prepared to be represented as roles and interactions on a system-as-is. It consolidates the initial system and stakeholders interactions with it.

- Analysis (system-as-is): It takes advantage of the formalization inserted in the previous phase and, based on this formalism, perform properties and heuristic analysis of the system-as-is to rule out redundancies and inconsistencies.

- Identification: It is a phase where needs and opportunities are identified on system-as-is and transformed on stakeholders requirements. Those former are classified and clustered on a set of services that can satisfy them, generating a consolidation strategy to build the system-to-be.

- Modeling (system-to-be): It is a phase where requirements are prepared to model process, roles and interactions for the system-to-be (based on the knowledge about the system-as-is). It consolidates the proposal and deepens the system requirements to rule out inconsistencies and redundancies. Subsystems or components are defined to handle aspects (objectives 
or functionality) of the system-to-be, eventually inserting some designer assumptions to cover some undefined points.

- Analysis (system-to-be): It takes advantage of the formalization inserted in the previous phase and, based on this formalism, perform properties and heuristic analysis of the requirements set to rule out redundancies and inconsistencies. Also, some links must be detected to reinforce traceability associating requirements to deliverable or linking agents to requirements in a responsibility relation.

- Validation: It is a phase that validates the conceptual system-to-be as a valid successor of the system-as-is. It is a validation process of the problem and to the solution proposed by stakeholders - under environment or contextual constraints. To perform a proper validation, it may be necessary to build simulations, prototypes or mock-ups to enable a deeper assessment of stakeholders needs under a environment context.

The whole discipline acts until the system-to-be converge to a stable solution. During Requirement Engineering stage the participation of stakeholders (customers, influencers and also internal actors of the systems) are used specially to validate the elicited requirements and the conceptually designed system-to-be.

PSA Design Discipline encompass and include stakeholders participation during the whole design process thus creating a co-design environment.

From what concern system's design, our main hypothesis is that the key issues are in the early phase of design stage. Therefore, PSA Design Discipline focus specially on Requirement Engineering stage, specially on Identification phase. However, from what concerns Service Design, the framework proposed by Oliveira (OLIVEIRA; SILVA, 2015; DUTRA; OLIVEIRA; SILVA, 2013) had the primary design modeling structure of the PSA Design Discipline, specifying the Identi- 


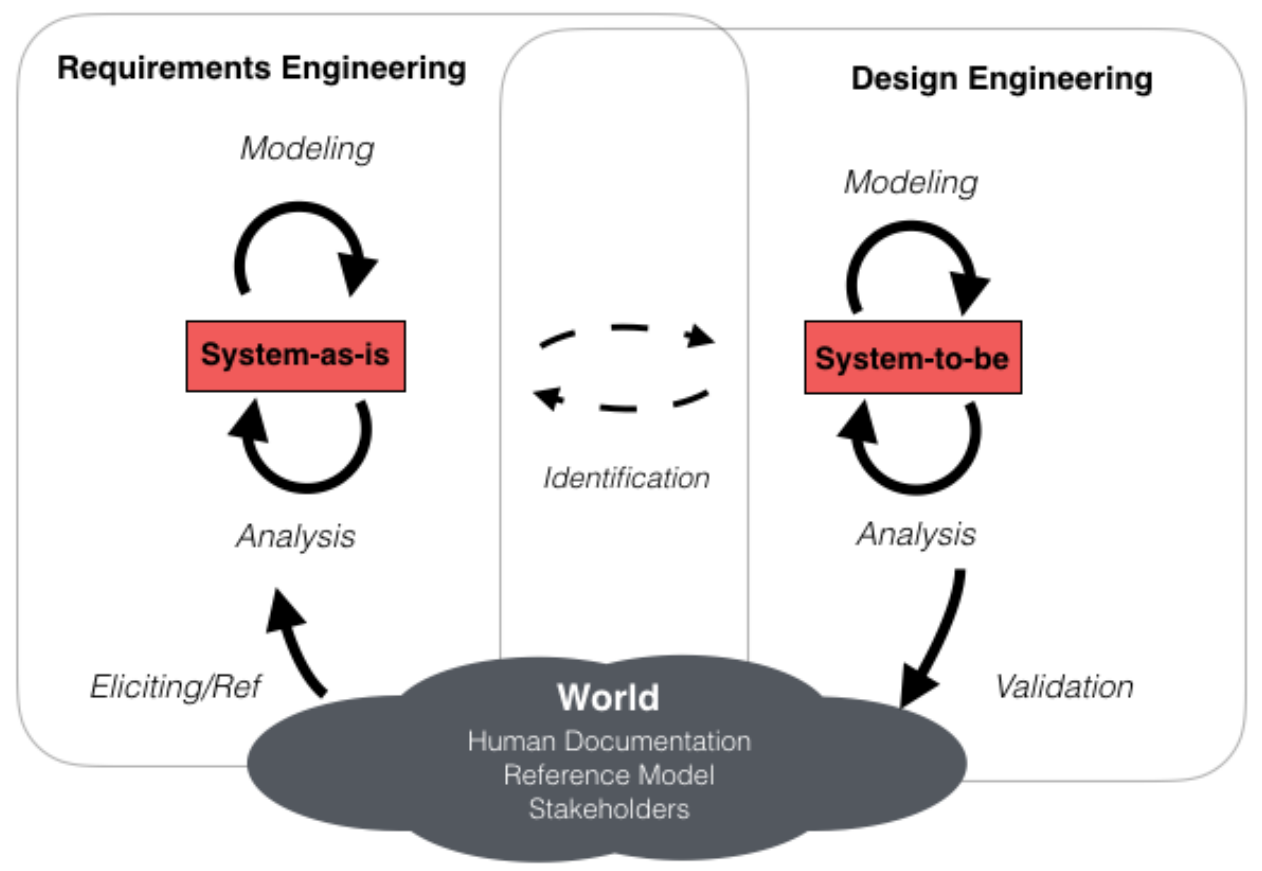

Figure 8: Service Design Discipline Basis. Figure created by author.

fication, Specification and Analysis phases (Fig. 9). Eliciting and Validation phases are intensive fields of research on Service Design, resulting on a wide sort of methods for eliciting and validating stakeholders viewpoints. In terms of Modeling and Analysis phases for the system-as-is, the first version, inherited from the previous service framework proposed by Oliveira, did not took in account, doing the Eliciting phase in parallel with Identification phase.

Therefore, for the first PSA Design Discipline, Identification, Modeling (system-to-be) and Analysis (system-to-be) phases are subdivided in:

- Requirement Model [Identification]: It is a phase that results into a requirement model that contains their relationships and organize them into viewpoints.

- Service Model [Identification]: It is a phase that supports the identification of the services that could satisfy the requirement model. The service model 
is the model that results from the representation of the relationship between the set of services and between the set of services and the requirements.

- Services Specification [Modeling]: It is a phase that defines the organization of the service system in terms of configurations of components, hierarchies and interactions between service-products components.

- Workflow and plan model [Modeling]: After a degree of specification it is necessary to create Plan and Workflow models reaching an even more detailed system-to-be.

- Satisfaction Analysis [Analysis]: It is an phase that identify the satisfaction of system-to-be characteristics to the requirements. It is as formal algorithm related to the modeling tools used on the previous phased.

- Workflow and plan analysis [Analysis]: It is an analysis of integrity and coherence using formal algorithms based on the previous language used to model the plan and the workflow.

Therefore, as an architecture, PSA defines a distributed architecture to product/service production arrangement based on a cloud system of systems. This structure inducts some strategic design decisions and includes sufficient information to allow high-level analysis and critical appraisal. To provide a mix of product-service artifact, following the PSA architecture, the PSA Design Discipline have the objective to provide:

- a service cloud package (from the legacy systems and the new designed ones);

- a model for the planner;

- a workflow model; 


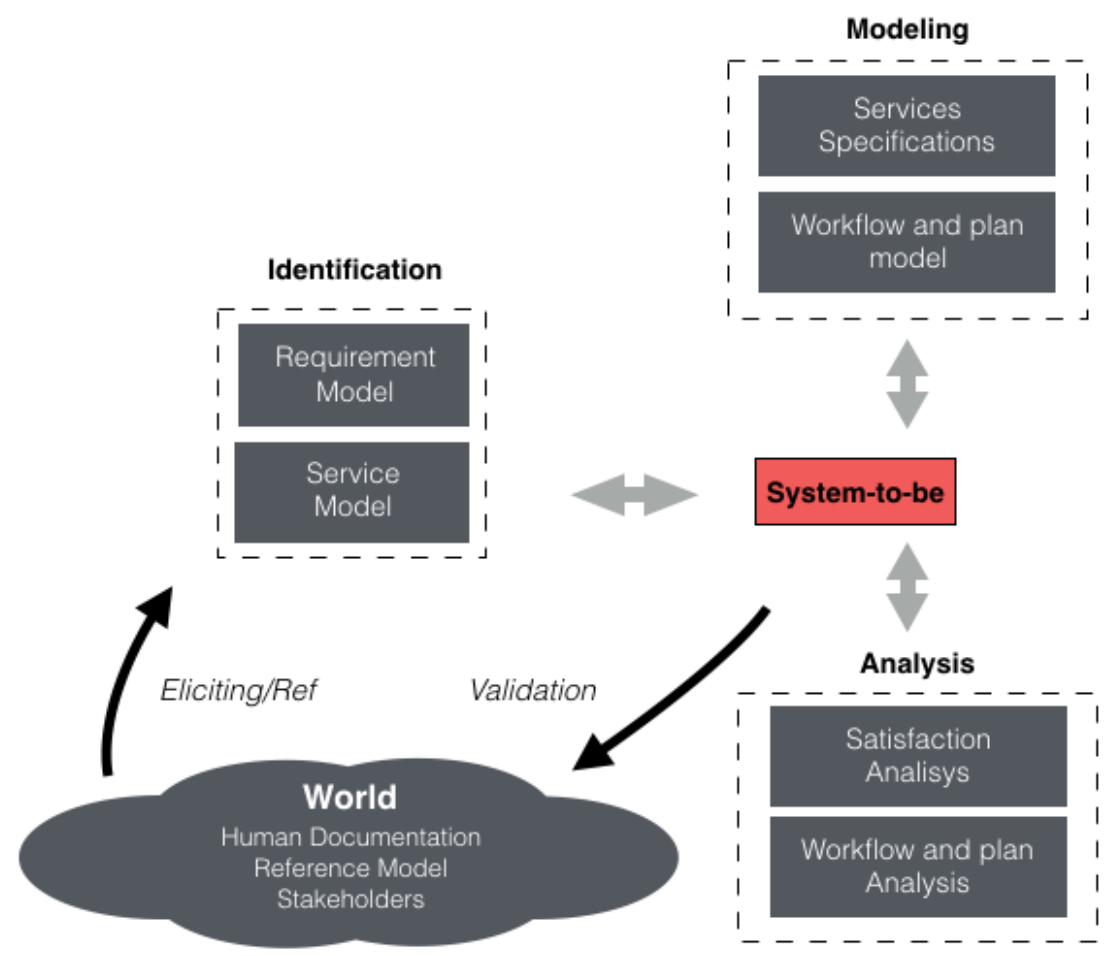

Figure 9: First Service Design Discipline for PSA. Figure created by author.

- a requirement model;

The first implementation of a Service Design following a similar structure was presented by Oliveira (OLIVEIRA; SILVA, 2015; DUTRA; OLIVEIRA; SILVA, 2013) that compiled modeling languages, design methodologies, analysis techniques and tools developed by the Design Lab of Escola Politecnica da Universidade de SÃ£o Paulo. As a primary work to the PSA Design Discipline, some modeling languages and analysis techniques explored by Oliveira, were imported to build the first version of the PSA.

Concerning the service cloud package, the PSA Design Discipline returns a SysML model (as a system-to-be) and a set of informational services implemented on a high-level language as Java or C\#. For both planner and workflow model, the PSA Design Discipline provides a Petri-net (PN) model that allows the inclusion of a model checking process in the analysis phase. From the Petri-net model it is 
generated a PDDL model to the planner. At least, for the requirements model, the PSA Design Discipline returns a SOMF requirement model (based on UML requirement model) that allows for a satisfaction analysis through the traceability module embedded on the Enterprise Architect (EA) modeling software tool.

As the PSA itself, the PSA Design Discipline is an ongoing research on Design Lab of Escola Politecnica da USP. The multiple efforts on the development of design tools as SoftDISS (Service design tool based on SOMF language implemented on EA software modeling toll) (OLIVEIRA, 2013), itSIMPLE (Planning Domains design tool based on Petri Nets that outputs a PDDL model for planners) (VAQUERO et al., 2007) and GHENeSys (An workflow and production system design tool based on an extended petri-net) (FOYO, 2001), presents the necessary competencies to choose and implement the best techniques for the PSA.

\subsection{Intentional PSA Service Design Discipline}

In order to reach a better value co-creation in the service delivery, prediction and monitoring for PSA, we propose a modification on the PSA Service Design Discipline introducing intentional elements. In fact, the intense customer participation on service systems and the different perception of value (related to each individual cognition process) points to a design process with greater model for stakeholders cognition. Our hypothesis is that agent oriented approaches could fit better than object-oriented modeling approaches to elicit, model and monitor value co-creation on service systems.

The Intentional PSA Service Design Discipline enriches the PSA Service Design Discipline using the Goal-Oriented Requirement Engineer (GORE) modeling approach. The intentional model, supported by i-Star $\left(i^{*}\right)$ approach, represents a multi-stakeholder model, their intentions and dependencies. Modeling and Anal- 
ysis phases are inherited from i* with other GORE methods in order to converge to a stable system-as-is.

The projection of an stakeholders's intention into a system-to-be, results in what we call an stakeholder's expectation. Those expectations represents highlevel requirements. Using an Expectation Model it is possible to identify several service's goals and create a Service Component Model. Each service, defined by a set of goals, can be specified using GORE language KAOS and from it, a petri-net model. Besides that, the close relationship between expectations and service's goals allows the development of a satisfaction algorithm to measure value co-creation.

The Intentional PSA Service Design Discipline, therefore, propose an approach to improve value co-creation design of the original PSA Service Design Discipline. The importance of this improvement arises from the essence of the Service System's definitions, where value co-creation is a central characteristic.

The basic general structure of the PSA Service Design Discipline remains, however, some phases and models (specially on the initial phases) will necessarily pass through important adaptations (see Fig. 10). The system-as-is is represented in an $i^{*}$ model, importing also its modeling and analysis phases. The "EarlyRequirement Model" on $\mathrm{i}^{*}$ approach is a model that represents (i) the context through the actors involved on the situation, (ii) their intentions (represented by their goals and activities) and (iii) their dependencies. On the other hand, the system-to-be is represented by a KAOS model representing the main service provider (its main goal and sub-goals) and its internal agents representing the necessary set of services that can deliver the designed value.

As intentional eliciting, modeling and analysis phases for the Intentional PSA Service Design Discipline, we are proposing the use of ERi* ${ }^{*}$ Method from Oliveira \& Leite (OLIVEIRA; LEITE, 2011; OLIVEIRA; LEITE, 2008). It presents a 


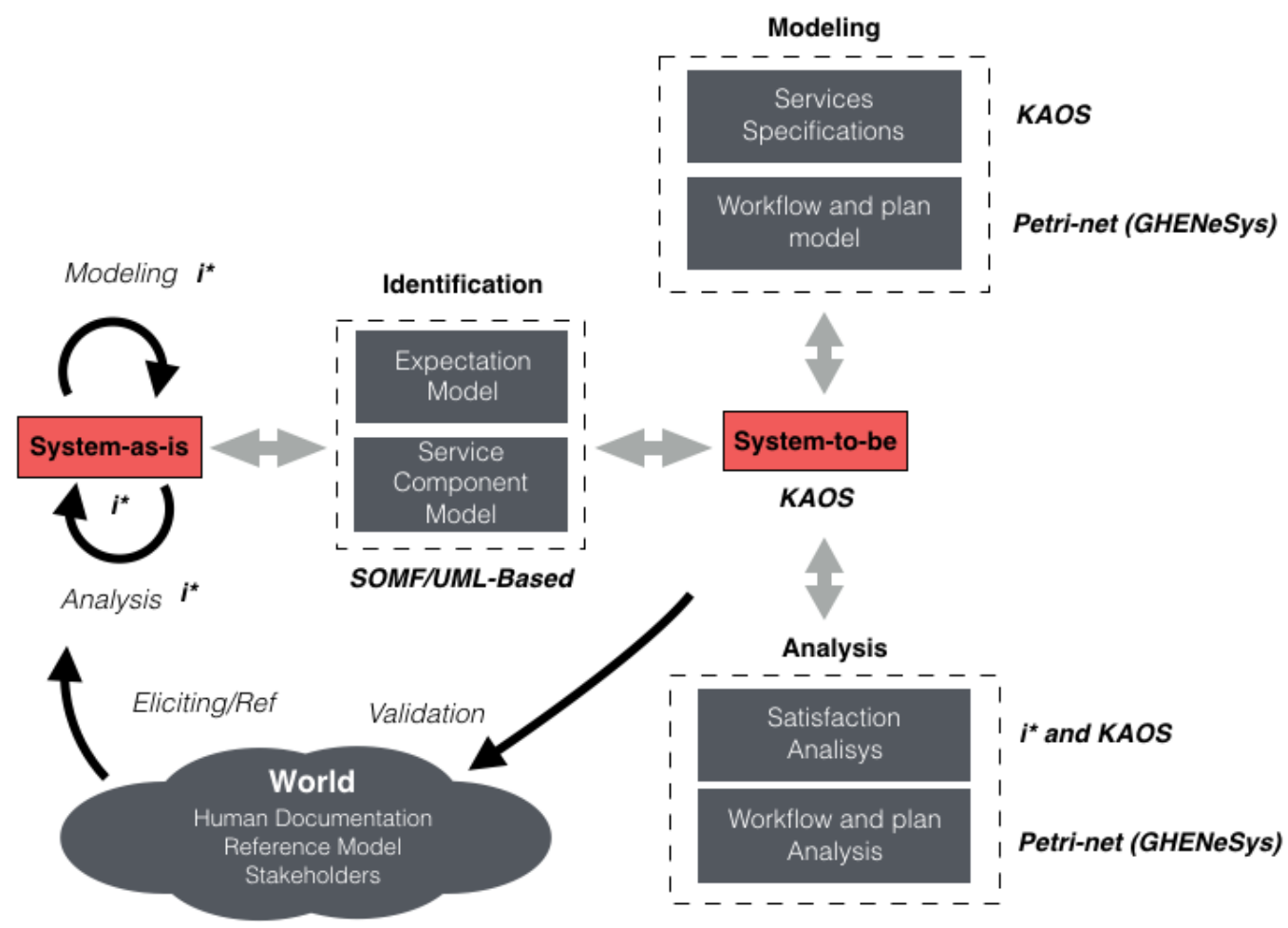

Figure 10: Intentional PSA Service Design Discipline. Figure created by author.

"bottom-up" strategy based on a Lexicon Extended Language (LEL) that provides an stable system-as-is model.

The identification phase is formed by expectation and service identification sub-phases. The expectation identification phase is a projection process from the intentions of the system-as-is into a opportunity space where, further, the systemto-be will be designed. The expectation model is a high-level requirements model that represents the relationship between expectations and viewpoints, and positive/negative relationships between expectations. Besides that, the expectation identification phase apply a viewpoint merging strategy in order to organize and collapse expectations to reach the best possible decoupled model. The service identification phase starts with a service generation session creating a first service component model. The service component model is a service concept model that represents the relationship between the generated services and the expec- 
tations, and also the positive/negative relationships between generated services. The final service component model is reached after the application of a service merging strategy, similar to the viewpoint one, organizing and collapsing services in order to reach the best possible decoupled service model.

The set of services on service component model is specified on a KAOS approach. That modeling process starts with the AND/OR decomposition of the main goal of each main service component. Internal goals, actions and resources can also be addressed to sub-agents on KAOS languages that represents subservices on PSA. Still on modeling phase, we developed a method (still an ongoing research) to transform KAOS models into Petri-net and PDDL models.

On Intention PSA Service Design Discipline, the analysis phase, in terms of workflow and plan analysis, keeps the strategies of model checking and invariant analysis from PSA Service Design Discipline. However, there is a great impact on Satisfaction Analysis module. As we understand the relationship between intentions, expectation and main service's goal, it is possible to modify some goaloriented satisfactions analysis algorithm (HORKOFF; YU, 2012) to encompass a value creation index. This effort will be addressed in a future work.

Under these conditions, Intentional PSA Design Discipline must provide ${ }^{1}$ :

- a service cloud package (from the legacy systems and the new designed ones);

- a model for the planner;

- a workflow model;

- an intentional model (that support intention prediction and value cocreation satisfaction module);

\footnotetext{
${ }^{1}$ Note that for the Intentional PSA Service Design Discipline proposition, the last output model changes from a requirement model to an intentional model
} 
The implementation of GORE modeling approach in PSA Service Design Discipline requires specially the development of an identification phase and their intrinsic models (Fig. 11). On this work we (i) developed both the expectation identification and service identification phases, (ii) defined the expectation and service component models, and (iii) specified both viewpoints and services collapsing strategies. This development, when coupled with GORE propositions and techniques, enriches the PSA Service Design Discipline improving its capability to create product-service systems that can co-create value.

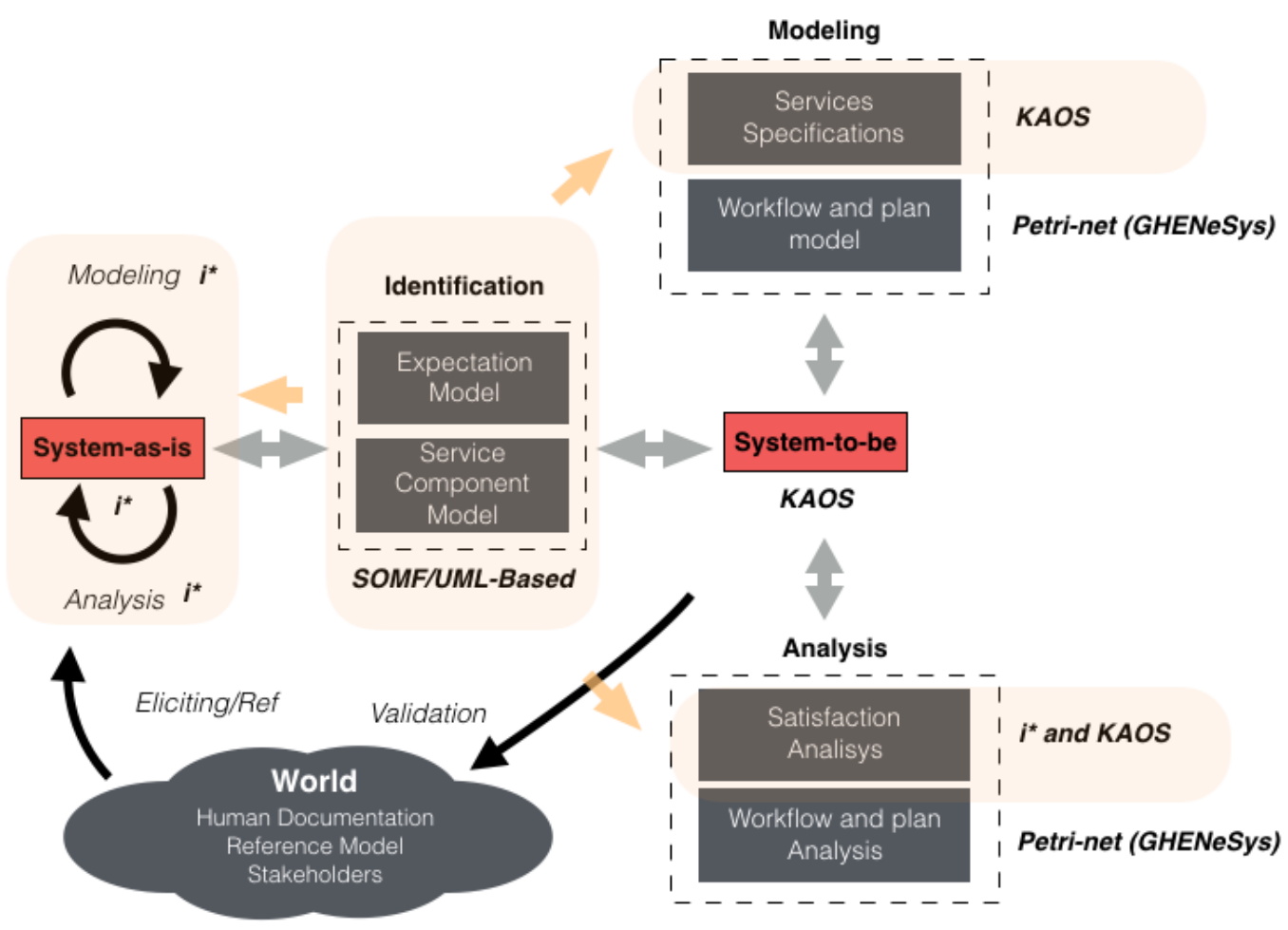

Figure 11: Development focus and Intention impact on PSA Service Design Discipline. Figure created by author.

In terms of modeling tools, Intentional PSA Service Design Discipline is supported by TAOM4E, a GORE modeling tool that supports system's design since early requirements using $i^{*}$, reaches late requirements using KAOS, details design using UML and perform software implementation on java or $\mathrm{C} \#$. For the identification phase, we used a small module of SOMF included in Enterprise 
Architect software package, to create both Expectation Model and Service Component Model. For KAOS transformation into petri-nets and PDDL models there is a tool in D-Lab called ReKPLAN that supports this specification process. At least, for petri-nets and workflow design there is GHENeSys modeling environment, which also supports a model checking analysis.

\subsection{Intentional Modeling}

Adapting formal techniques used for modeling agents in artificial intelligence, Eric Yu (YU; MYLOPOULOS, 1995) developed the i* Framework, using representational constructs and mechanism to build models of intentional agents.

Agent behavior, on Artificial Intelligent research field, have been modeled in terms of intentional concepts such as belief, goal, ability and commitment. Even if Yu's framework remains rooted on those concepts, its intentional modeling proposition follows a different way.

Intentionality means agent's interests and motivations. On i*, intentions are modeled looking to the agent's external intentional relationships and also their internal intentional features.

To represent external intentional relationships, the framework represents actors involved (as a node) and four different possible dependency links between those actors (see Fig. 12).

Besides tasks and resources that could represent activities and flows in a process, the intentional process model, as a whole, aims to capture the underlying motivations and intents behind it, including goals and softgoals dependency links.

A goal dependency means that one depends on the other to achieve a certain well defined state in the world. On the other hand, a softgoal dependency means that one depends on the other to achieve a certain fuzzy state in the world, 


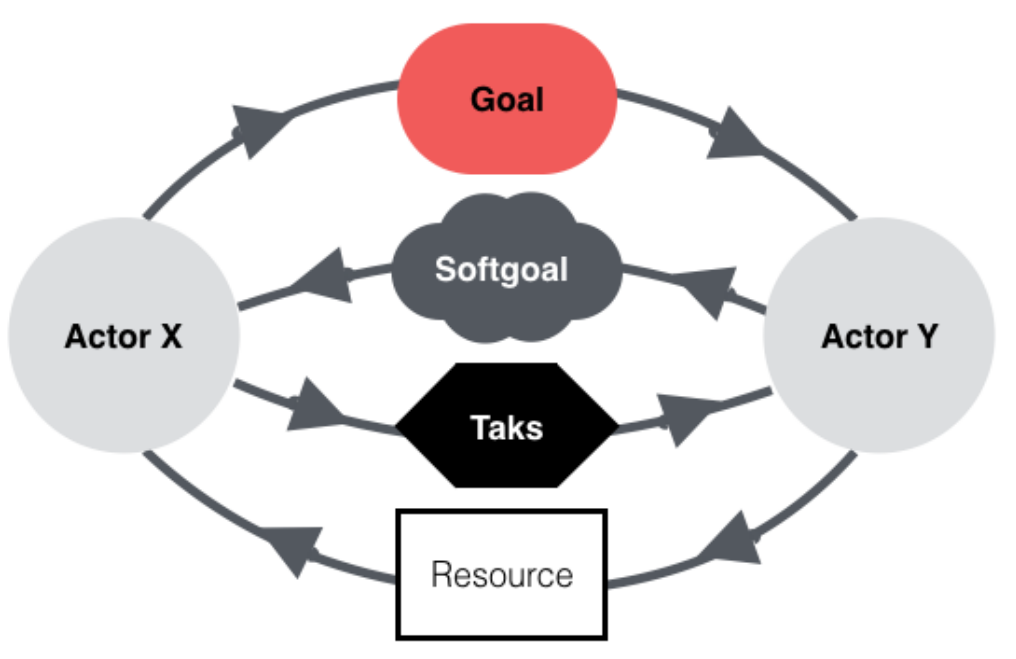

Figure 12: External Intentional Relationships. Adapted from (YU; MYLOPOULOS, 1998)

normally linked to performance, quality, security, facility and so on.

For internal intentional features, Yu proposes a structure formed by the same four basic elements, linked through means-ends and decomposition relationships. That structure aims an explicit representations of the "whys" and "hows" that support cognition alternatives of the agent (see Fig. 13).

In a means-ends link, usually a task represents a mean to attains (i) a goal to be achieved, (ii) another task to be accomplished, (iii) a resource to be produced, or (iv) a softgoal to be satisfied. Otherwise, a task decomposition link represents a decomposition of a task in four types: subgoals, subtasks, resourceFor and softgoalFor.

Therefore, by being agent oriented, $\mathrm{i}^{*}$ framework conveys these intentional forces from where they are coming from, and through they are directed towards. At any node when one asks a "how" question, a mean is sought having the current node as its desired end state. Conversely, when one can ask a "why" question, one seeks to discover the end state for which the current node is the mean. 


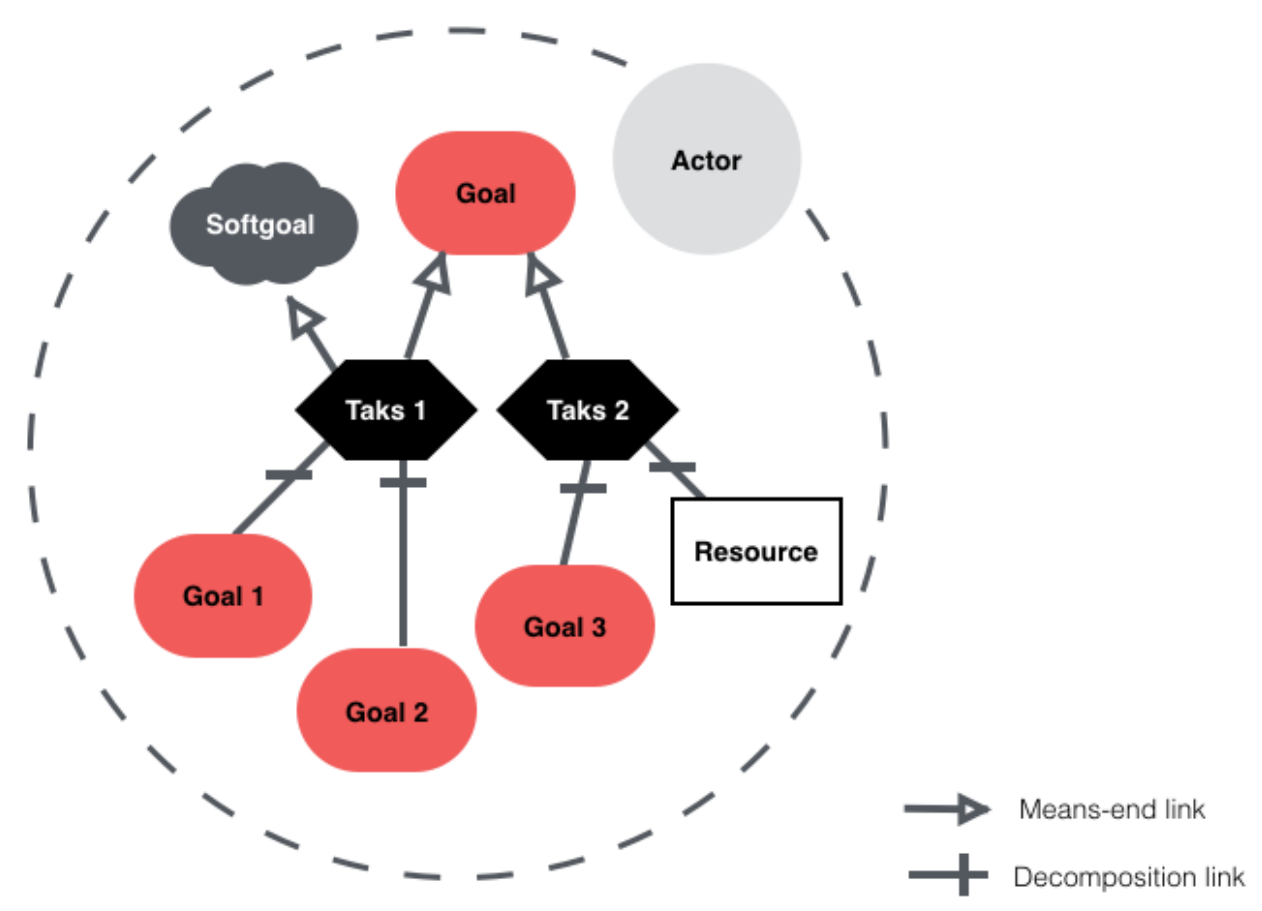

Figure 13: Internal Intentional Features. Adapted from (YU; MYLOPOULOS, 1998).

By being able to express why and how, the model gives a deeper understanding based on means-ends reasoning. Consequently, it represents a sort of decision alternatives for each actor and supports actors' individual choice. On that manner, its is possible to see that $i^{*}$ proposes a very consistent modeling approach to intentional agents still keeping its roots in artificial intelligence characteristics.

\subsection{From System-as-is to System-to-be: Introducing Ex- pectations}

In terms of intentional strategies to system-to-be identification neither i*, KAOS or Tropos proposes a clear and broad discipline to identify opportunities, prioritize and propose new solutions. In fact, after a first requirement phase, none of these approaches has a generation of possible alternatives phase. Consequently, they eventually proposes a biased system-to-be or just incremental improvements 
in the system-as-is' features.

Besides that, identifying service systems (or product-services systems) demands different modeling strategies than those used for products or software information systems. Even approaches denominated service-oriented, as SOMF and others SOA-based, present a poor treatment for this phase.

An important contribution of this work is the path we propose for the Intentional Identification phase, bringing the development from the system-as-is to a system-to-be, generated and analyzed as a service system.

To implement the Intentional Identification phase we have, first, to introduce the notion of Expectation.

Expectations are projections of Intentions in a system-to-be (or in a space of opportunity) (Fig. 14). While external/intentional relationships are related to a stabilized relationship with other agents, expectations are an evolving set of elements that define the relationship with a (future) service system.

Expectations are firstly identified from the intention's model elements and projected on the system-to-be, structuring the first expectation's model. It is from an expectation model that an service set is identified, modeled and verified. Since the service model stabilizes, the expectation set is consolidated. Expectations then represents the relationship between agents (stakeholders) and the service system (system-to-be). This allows for an analyses of satisfaction, during analysis phase, and also for a model supporting value co-creation satisfaction module on PSA (both to be addressed in future works).

\subsection{Intentional Identification Phase}

The identification phase, from an intentional and service perspective, is responsible for the identification of a expectation model from an intentional model 


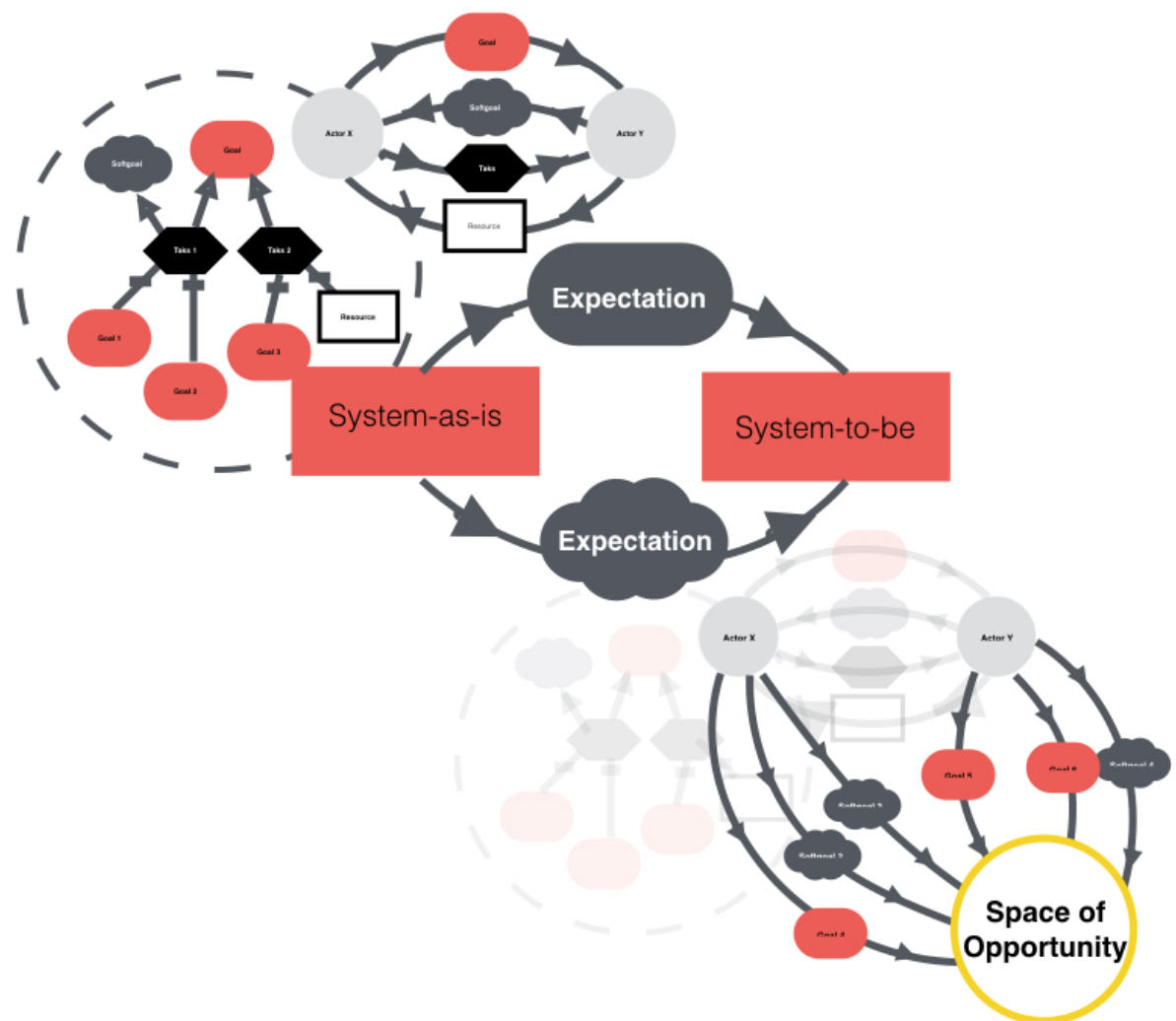

Figure 14: Intentions and Expectations. Figure created by author. 
(systems-as-is) and for the generation of a service component model that will propose the first concepts of the system-to-be.

\subsubsection{Expectation Model}

To generate an Expectation model, there are three main modeling steps: (i) expectations identification, (ii) viewpoint inclusion and association, and (iii) expectations influence relationship.

For expectations identification step, the starting point is an intention model representing a system-as-is (fig. 15). The projection of intentions on an space of opportunity can be explored from four types of heuristics:

1. Delegation/improvement of some goal (or sub-goal) execution to a new service-product system. Normally this kind of projection are identified by discovering possibilities of improvement or even diagnosed problems in the satisfaction of goals (or sub-goals).

2. A better realization of softgoals (or sub-softgoals). Normally this kind of projection is identified by a list of improvements required on the delivery of the service. It can be in terms of effectiveness, quality, usability and son on.

3. A new goal/softgoal opportunity generated by a task. A task normally is connected to a goal from a means-end relationship. However, a single task can achieve multiple goals during it execution. This can open an space to generate an new goal/softgoal opportunity.

4. A new goal/softgoal opportunity generated by a new tasks opportunity related with a resource. This is a more indirect way of projection, coming from a resource that is managed by an existing task, and could provide new 
opportunities if being related to new tasks that is connected to different goals/softgoals.

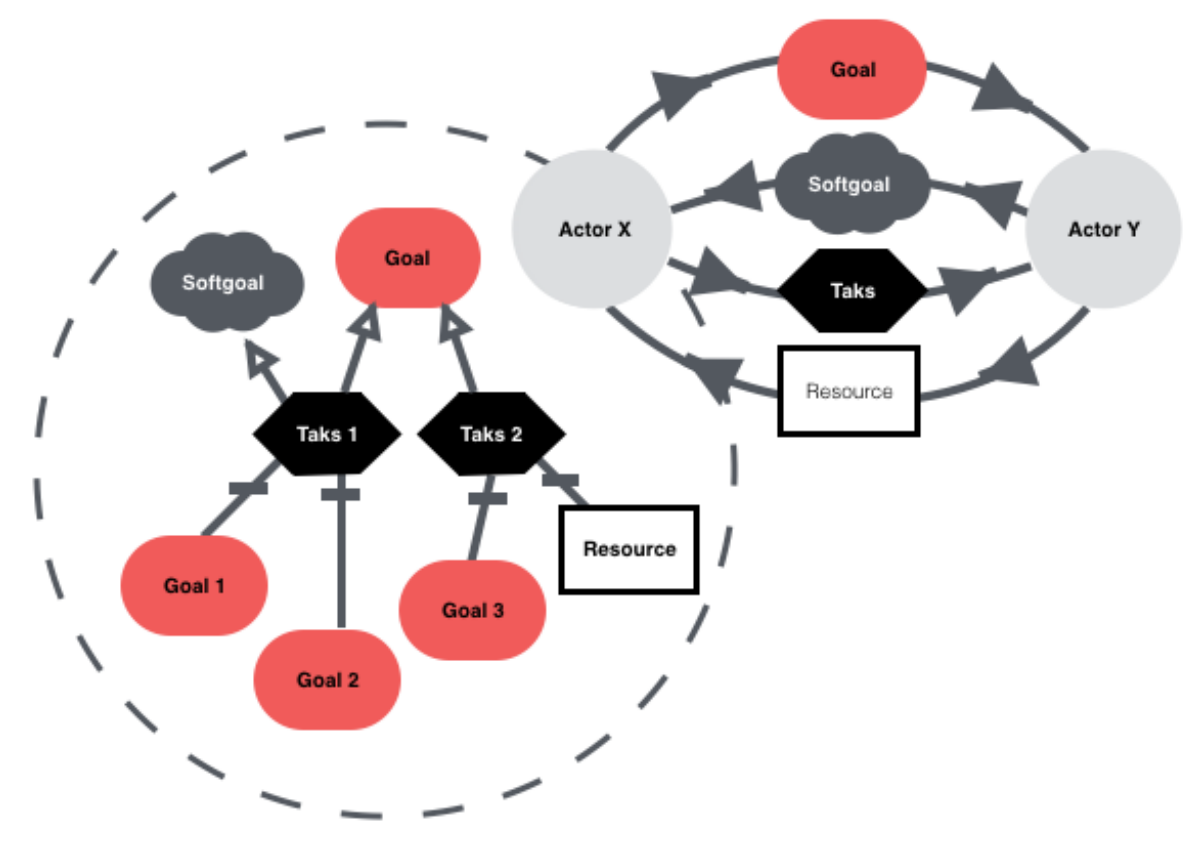

Figure 15: System-as-is. Adapted from (YU; MYLOPOULOS, 1998).

Those projections of intentions on an space of opportunity (fig. 16) creates a set of goals and softgoals dependencies that form the first expectations model (fig. 17).

On the expectation model, all expectations has at least one connected actor resulted from the projection of intentions process. Each actor represent one viewpoint for the expectations, however, in system engineering, a viewpoint can have a broad meaning representing all the "partial aspect of a [system] architecture that shows specific properties of a [...] system" (SAWYER; KONTONYA, 2001). The second step, viewpoint inclusion and association, provides an space to identify other viewpoints not direct related to the actors, for example, characteristics or concerns viewpoints. Security or Legal viewpoints are examples of possibles additions to the expectations models, including new expectations or and associating 


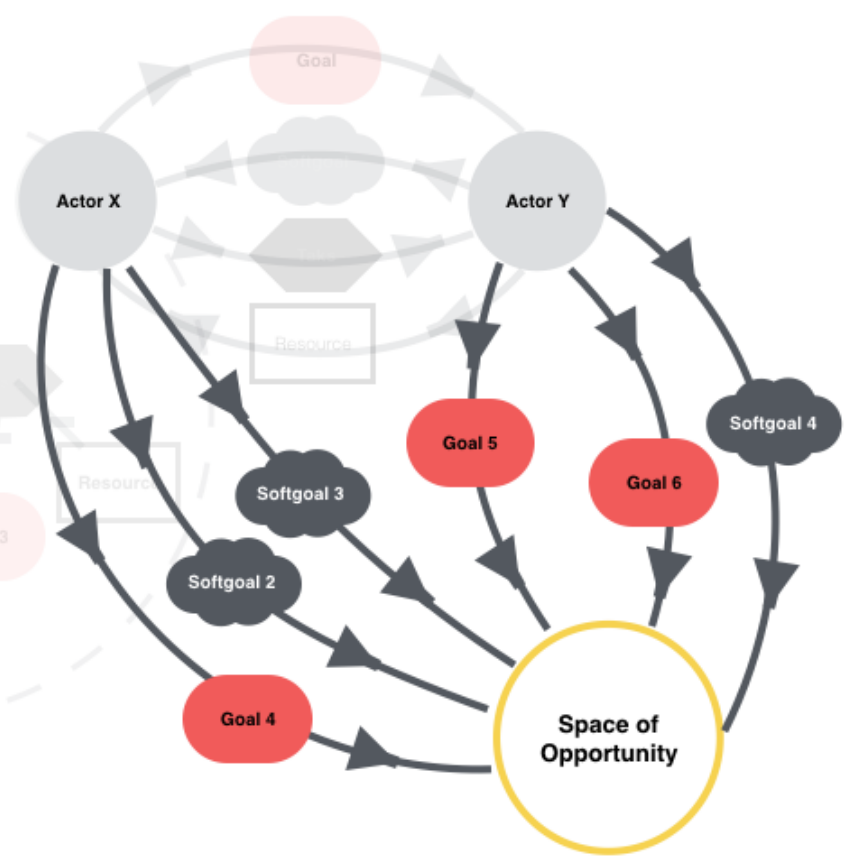

Figure 16: Projection over a Space of Opportunity. Figure created by author.
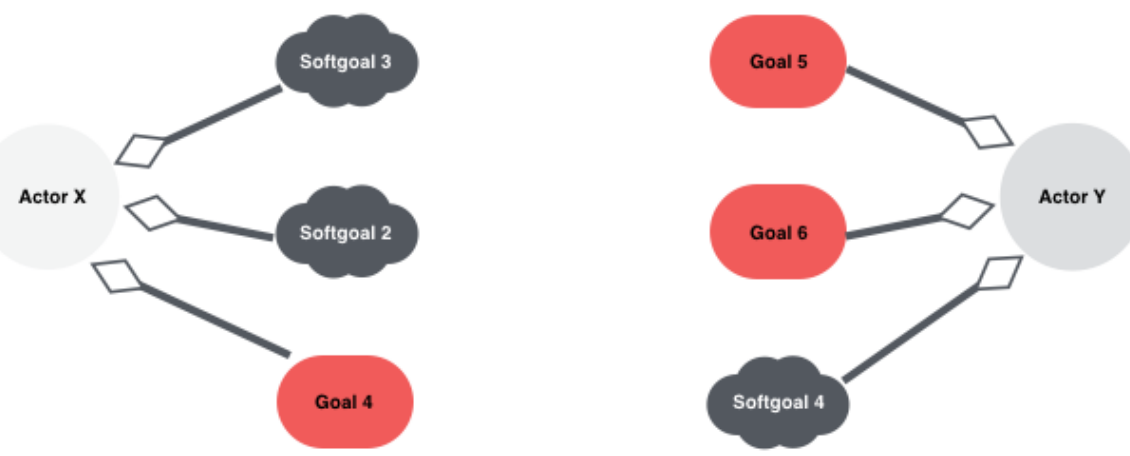

Figure 17: First Expectation Model. Figure created by author. 
the new viewpoint to an existing expectations from others viewpoints.

After viewpoint inclusion and association, the next step is to identify expectations influence relationships. There are three types of influence relationships between expectations: (i) positive influence, (ii) negative influence and (iii) neutral influence. Through an expectations relationship matrix, each relationship pair may be evaluated (fig. 18).

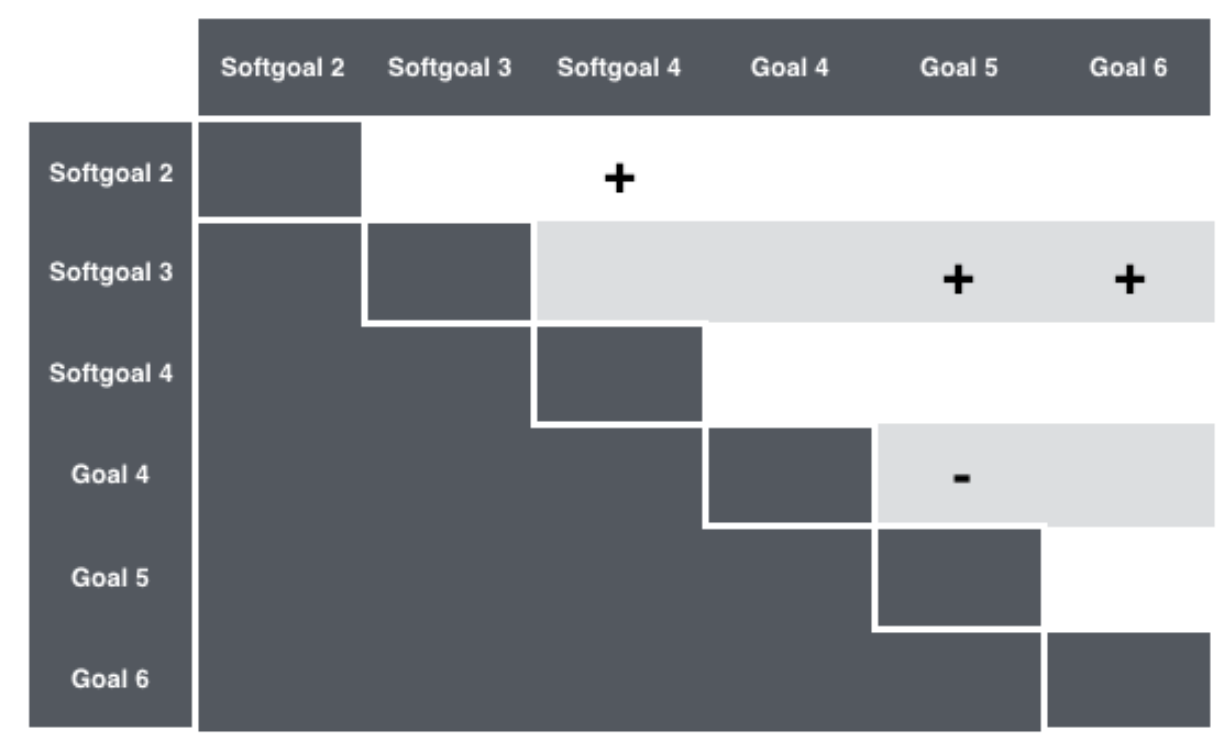

Figure 18: Expectation Influence Matrix. Figure created by author.

A positive influence on an expectation pair means that one expectation being satisfied will influence positively the satisfaction of the other. The negative influence means that the satisfaction of one expectation can influence negatively to the satisfaction of the other. The neutral influence means that the expectation pair do not have effect either positive or negative between each other. The expectation influence matrix can be transformed on an expectation influence model keeping tracking of the viewpoints connections (fig. 19). 


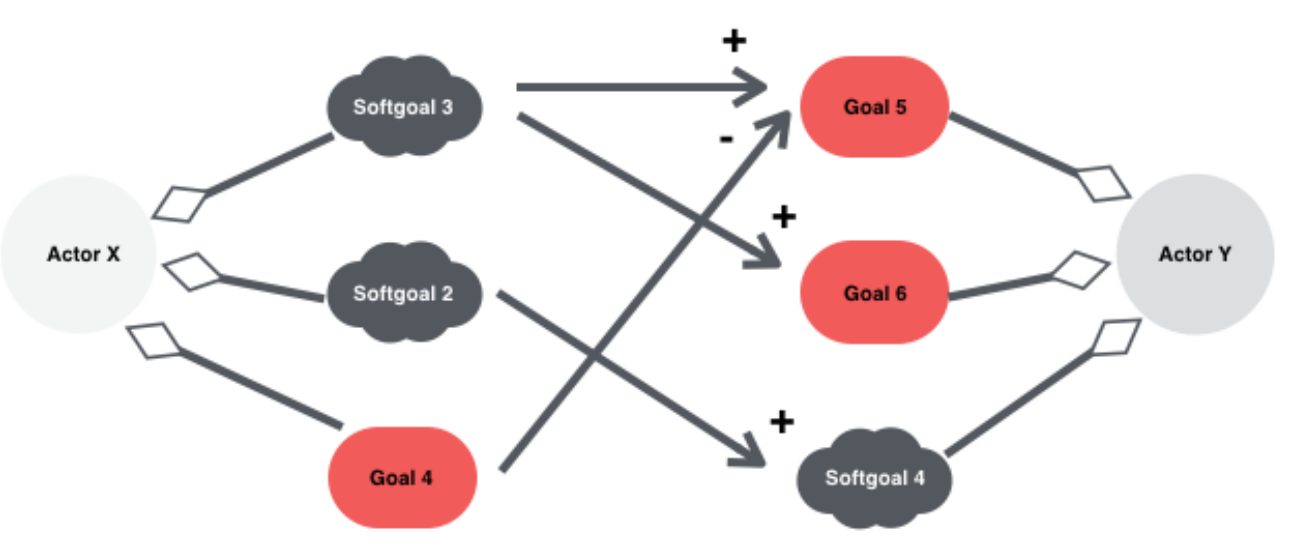

Figure 19: Expectation Influence Model. Figure created by author.

\subsubsection{Service Component Model}

Thereby, to generate a service component model, there are four main modeling steps: (i) expectation clustering, (ii) service generation, (iii) service collapsing strategy, (iv) system-to-be formation.

From the influence matrix, a clustering algorithm is applied to separate different islands of expectations, maintaining also negative influence.

An Expectation Cluster $x c_{i}$ is a set of expectations $e_{i}$ that are related two-bytwo. For each expectation $e_{i}$ on the Relationship Matrix ExE, the algorithm find all $e_{j}$ that has an influence relationship, and for each $e_{j}$ found, it search others $e_{i}$ that has an influence relationship. Since there are no new influence relationship, a cluster is formed with all those connected expectations (fig. 20).

For cases where the influence matrix has a higher number of relationships, a second cluster strategy must be applied: Clustering Circuits Strategy.

The circuit identification clustering method, identify a positive influence circuit between three expectation elements. Each three expectations $e_{i}, e_{j}$ and $e_{k}$ that represent a positive circuit form a cluster $x c_{i}$. In other words, for each $e_{i}$ that has a positive influence link with $e_{j}$ and $e_{k}$ if $e_{j}$ has also a positive influence 


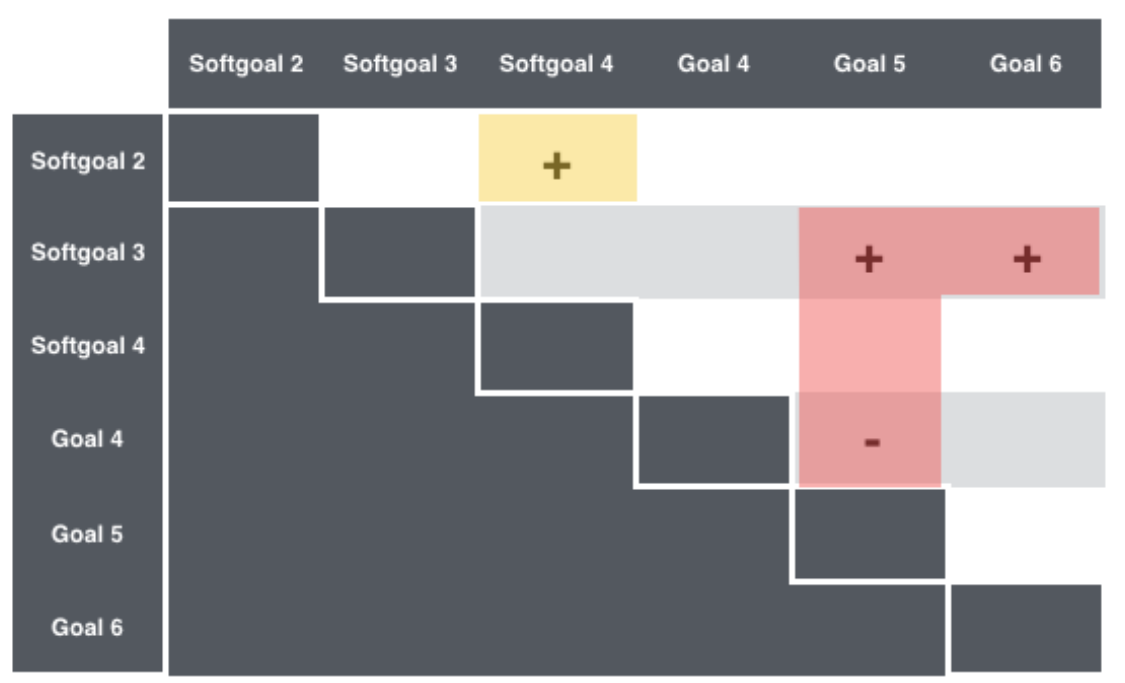

Figure 20: Clustering Formation. Each color identifies a cluster following the algorithm. Figure created by author.

link with $e_{k}$, they will form a circuit cluster $x c_{i}$.

Elements that do not form a circuit remains on the previous clustering method connecting to just one expectation element (fig. 21).

Proceeding on the expectation clustering step, from the influence matrix, the expectations model is evolved mapping the clusters on a spacial visualization of the expectations (fig. 22).

Is that from the cluster's expectation model that the service generation step starts, Intentional Identification phase's second step. For every positive chain of each cluster, a service proposition is generated. Each service proposition has a definition that means, in high-level way, a system that seams to attends all related expectations. Each negative break in a chain has to generate a independent service proposition (fig. 23).

The service Generation Model can be extended to present its relationships with the viewpoints (fig. 24). The negative influences and the number of expectation satisfied by viewpoint will be the variables used to the service collapsing 


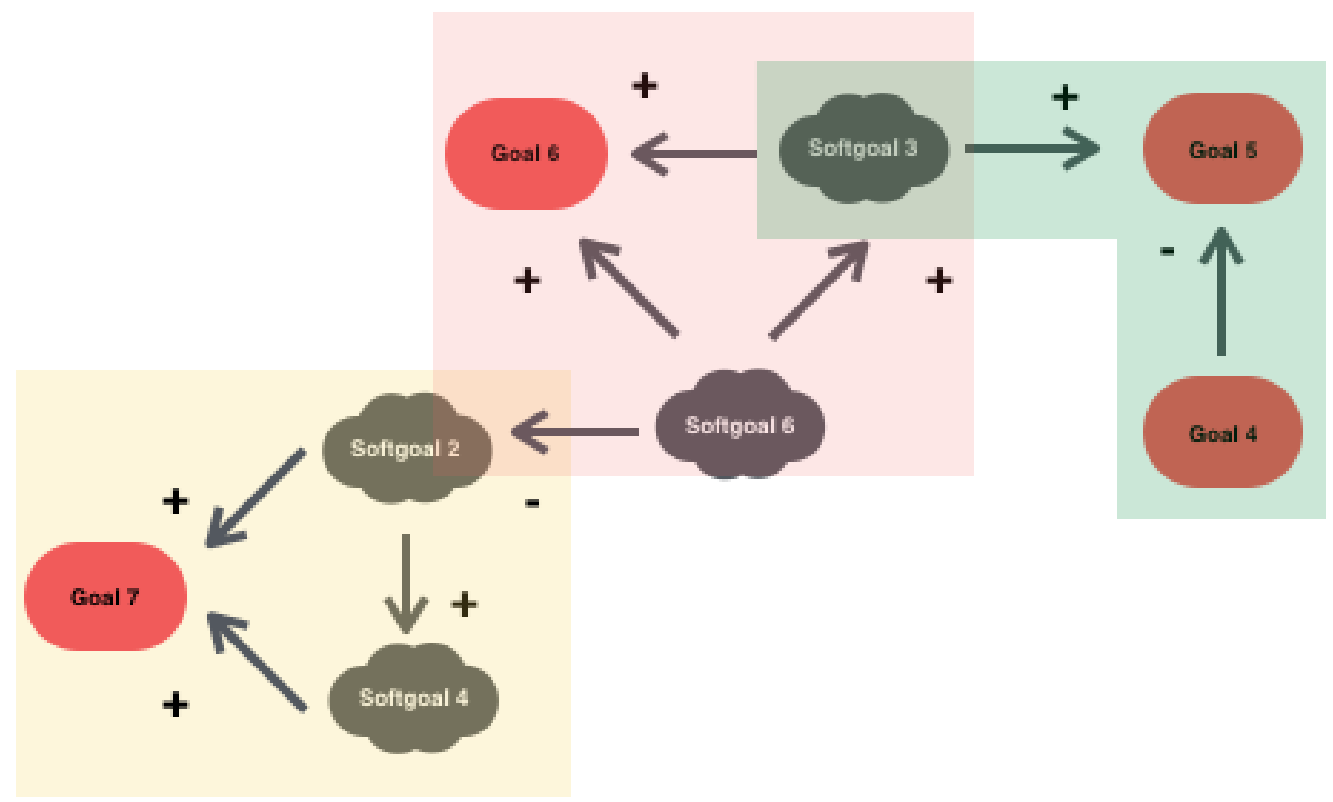

Figure 21: Clustering Circuits Strategy. Figure created by author.

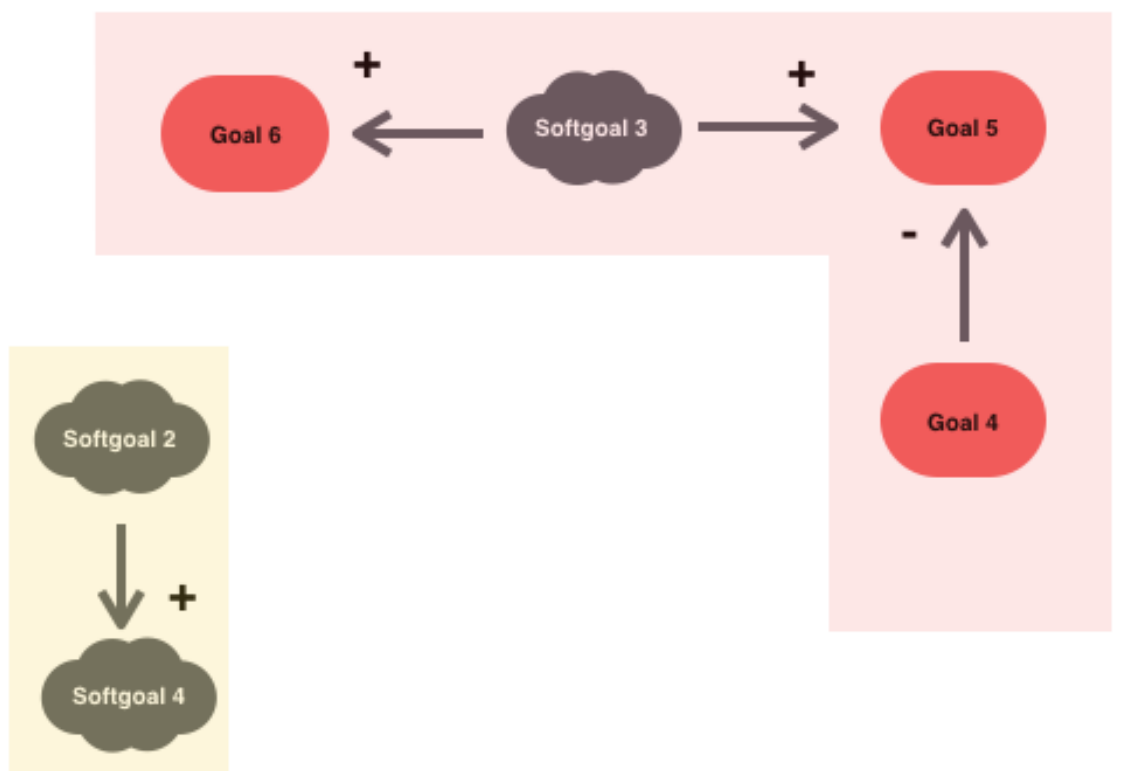

Figure 22: Expectation's clusters. Figure created by author. 


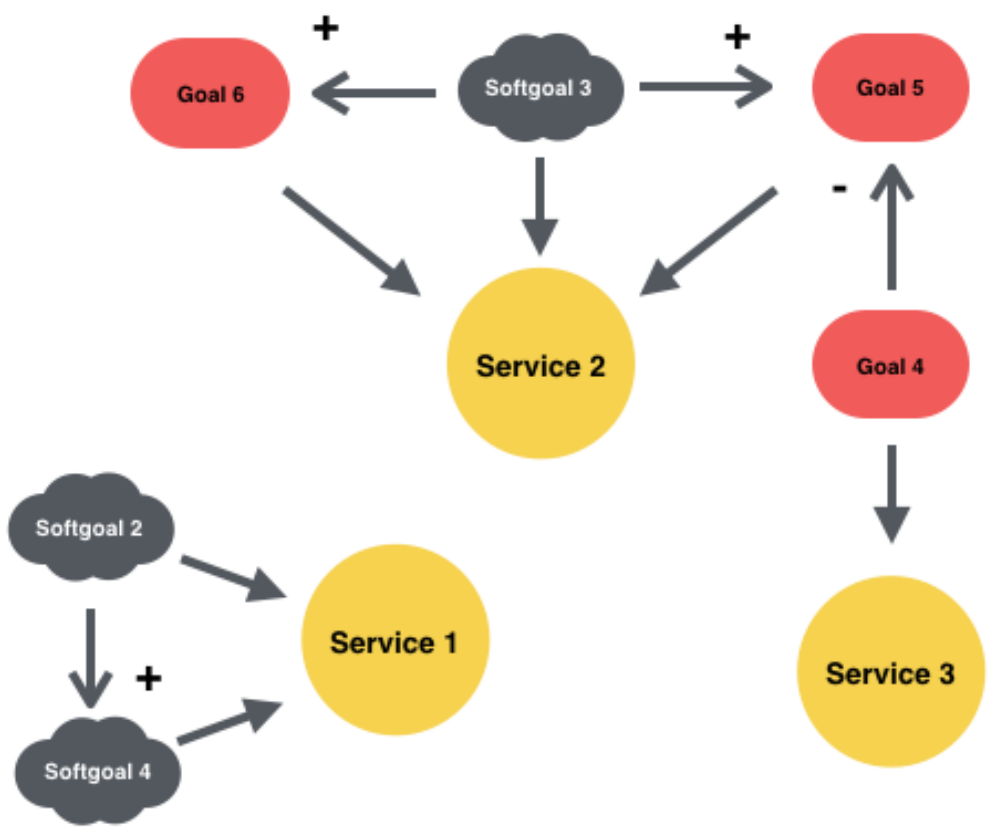

Figure 23: Service Generation. Figure created by author.

strategy step.

The aim of the service collapsing strategy is to find a minimum set of services that can attend all the expectations following an optimization strategy based on a viewpoint satisfaction rule.

As a principle, services whose expectations have negative influences relationships, can not be merged. All other merging combinations can be done and probably will generate different combinations of services solutions. In order to create a minimum set of services, the strategy proposes to combine all services that are able to be collapsed into one service.

However, that combination must follow an optimization criteria based on a viewpoint satisfaction rule. It is possible to optimize the collapsing looking for the maximum set of expectation satisfaction, for the whole system encompassing all viewpoints. Or it is possible to seek for the maximum set of expectation satisfaction for a single viewpoint. Each optimization criteria will generate a collapse 


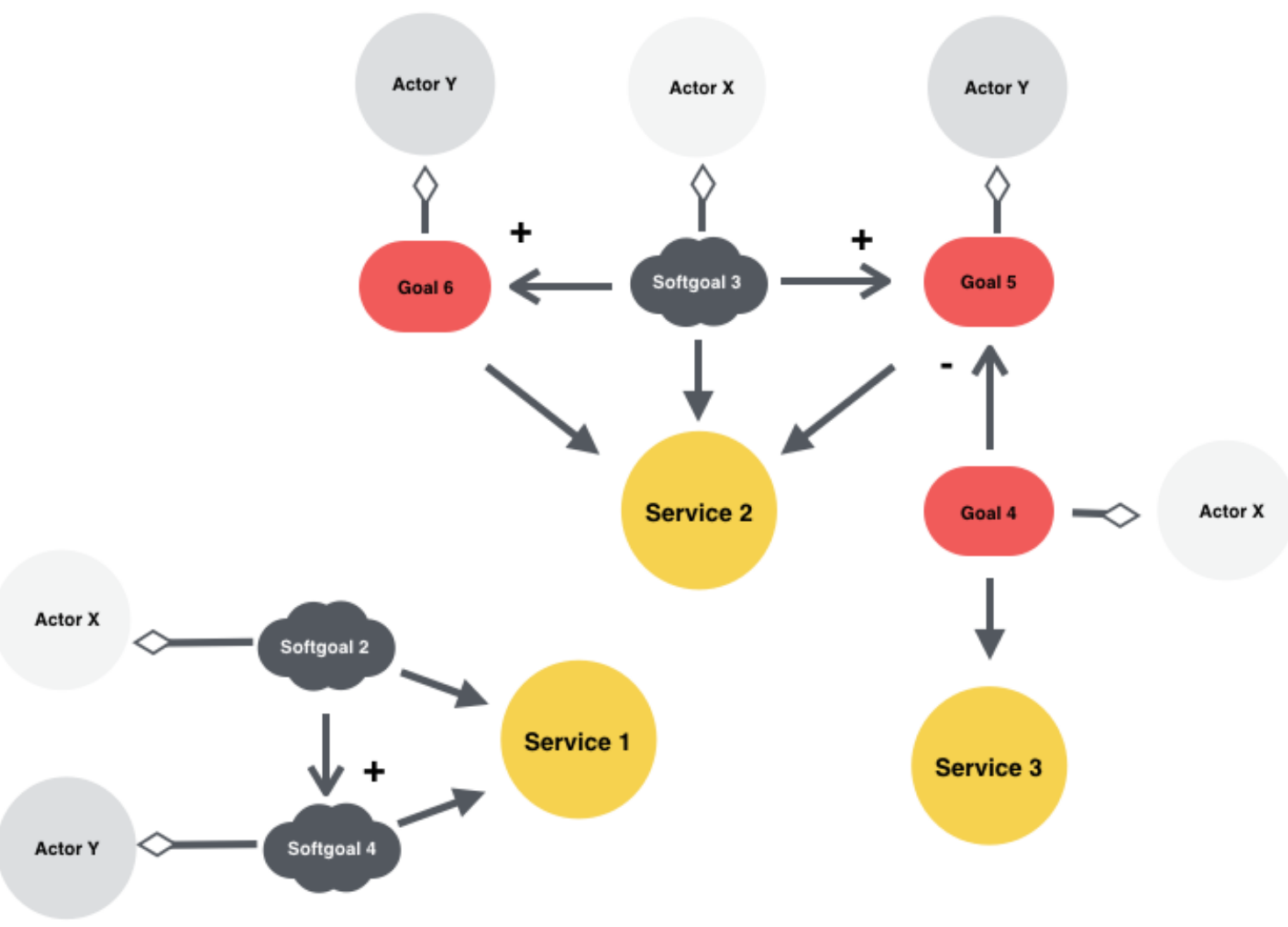

Figure 24: Viewpoint Service Model. Figure created by author. 
that will form a service that seek for the satisfaction of all the expectations related to it. On the figure 25 it is represented an expectation attendance matrix representing the number of expectations attended by the services related to each viewpoint. From a global optimization criteria, collapsing service 1 and service 2 will attend 5 expectation when service 1 and service 3 could attend just 2. However, for an optimization criteria using the viewpoint of Actor X both collapsing strategies attends the same numbers of expectations.

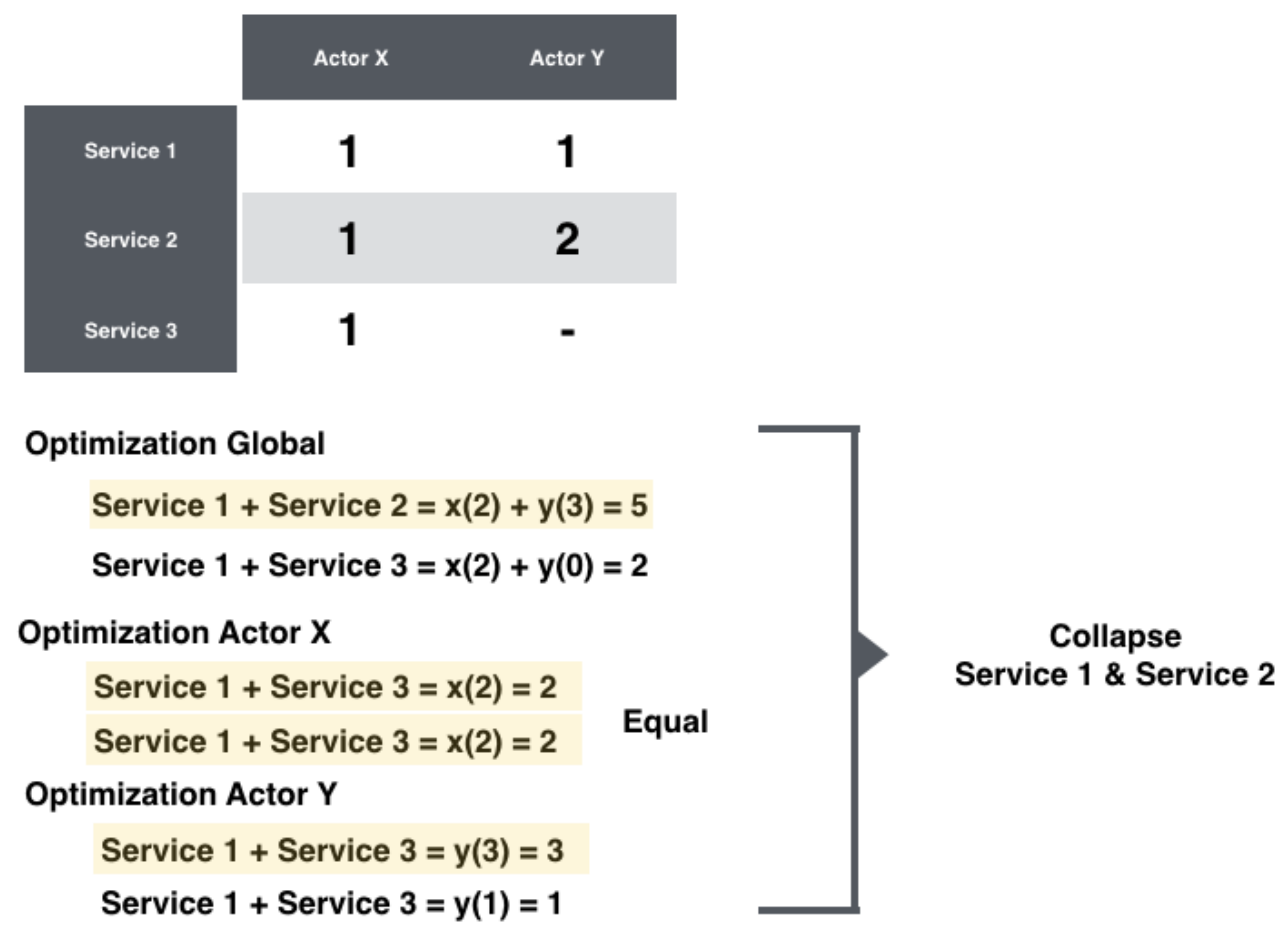

Figure 25: Service Collapsing Strategy. Figure created by author.

Therefore, service collapsing strategy is defined as: (i) Create an expectation attendance matrix, (ii) Choose an optimization criteria based on a viewpoint satisfaction rule, (iii) calculate an attendance index for all possible service combinations, (iV) take the combination with higher attendance index and (v) create a new service that represent the combination of all collapsed services.

For this last step in service collapsing strategy both services collapsed and the expectation reached should be taken in account on the identification of the 
high-level service definition (fig. 26 and fig. 27).

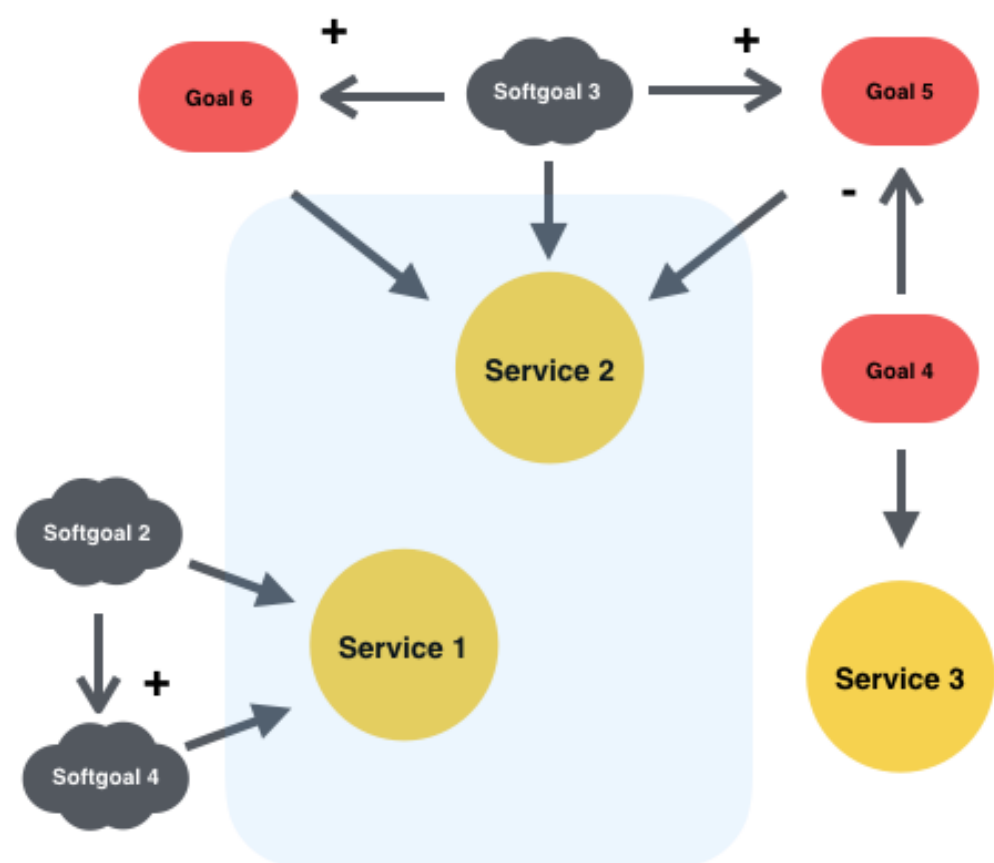

Figure 26: Collapsing Final Services - Part 1. Figure created by author.

As the last step of the generation of the service component model, the systemto-be formation starts with the collapsed service set to be positioned on the system-as-is model. That will form the first system-to-be model (fig. 28).

The first expectation set is positioned as dependencies with the service systems. However, after their identification, the set of expectation may be transformed as the service get into the specification and analysis phases (fig. 29).

The following phase, Specification, will take this first system-to-be model and organize the components, sub-goals and tasks to satisfy the expectation set. The main method used to decompose and specify the service system is KAOS goal-oriented design method (fig. 30). 


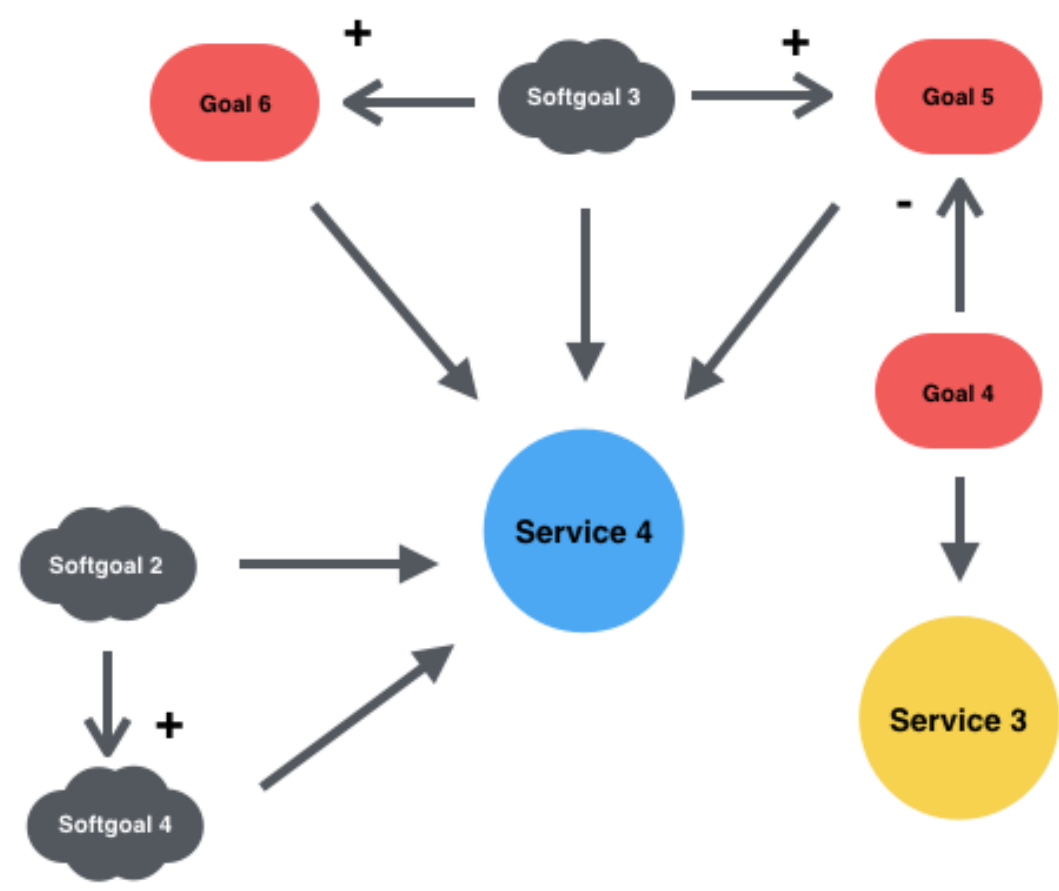

Figure 27: Collapsing Final Services - Part 2. Figure created by author.

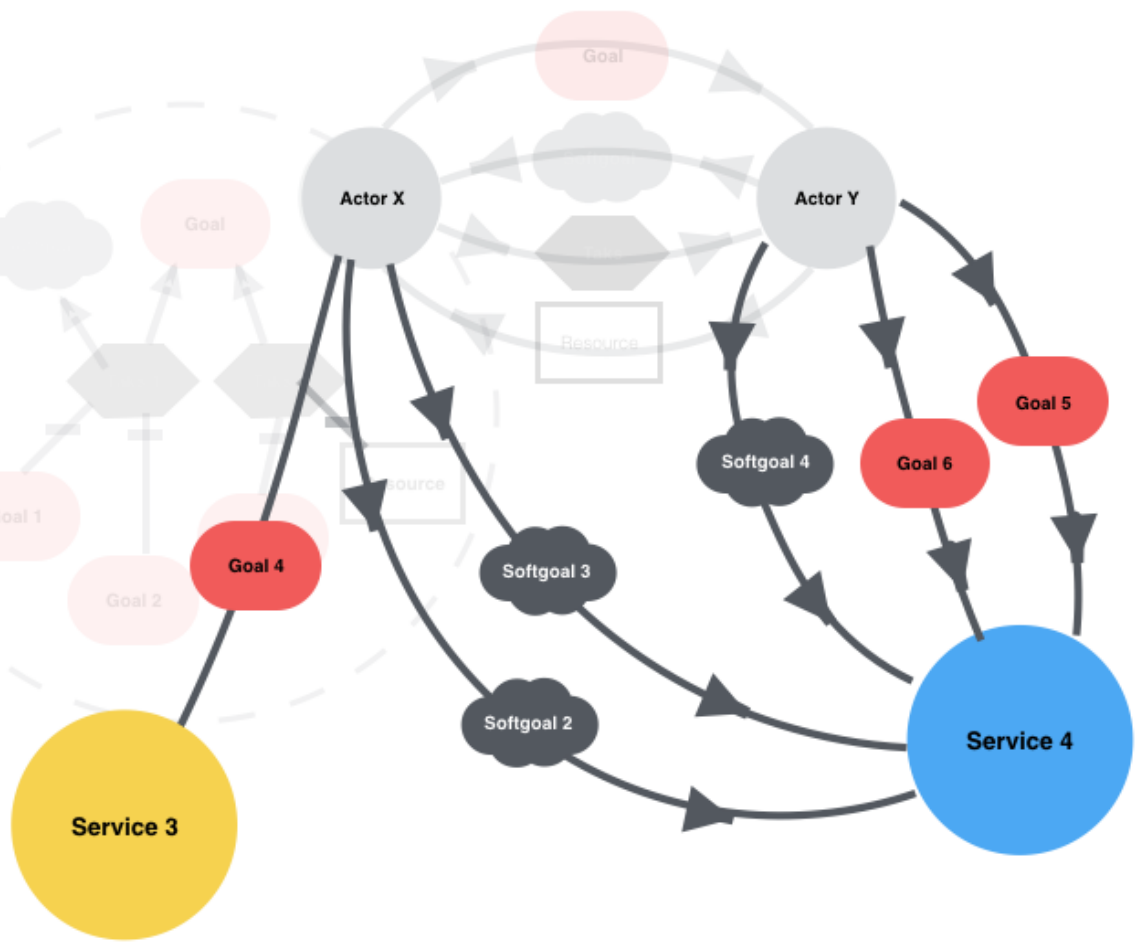

Figure 28: Primary System-to-be model. Figure created by author. 


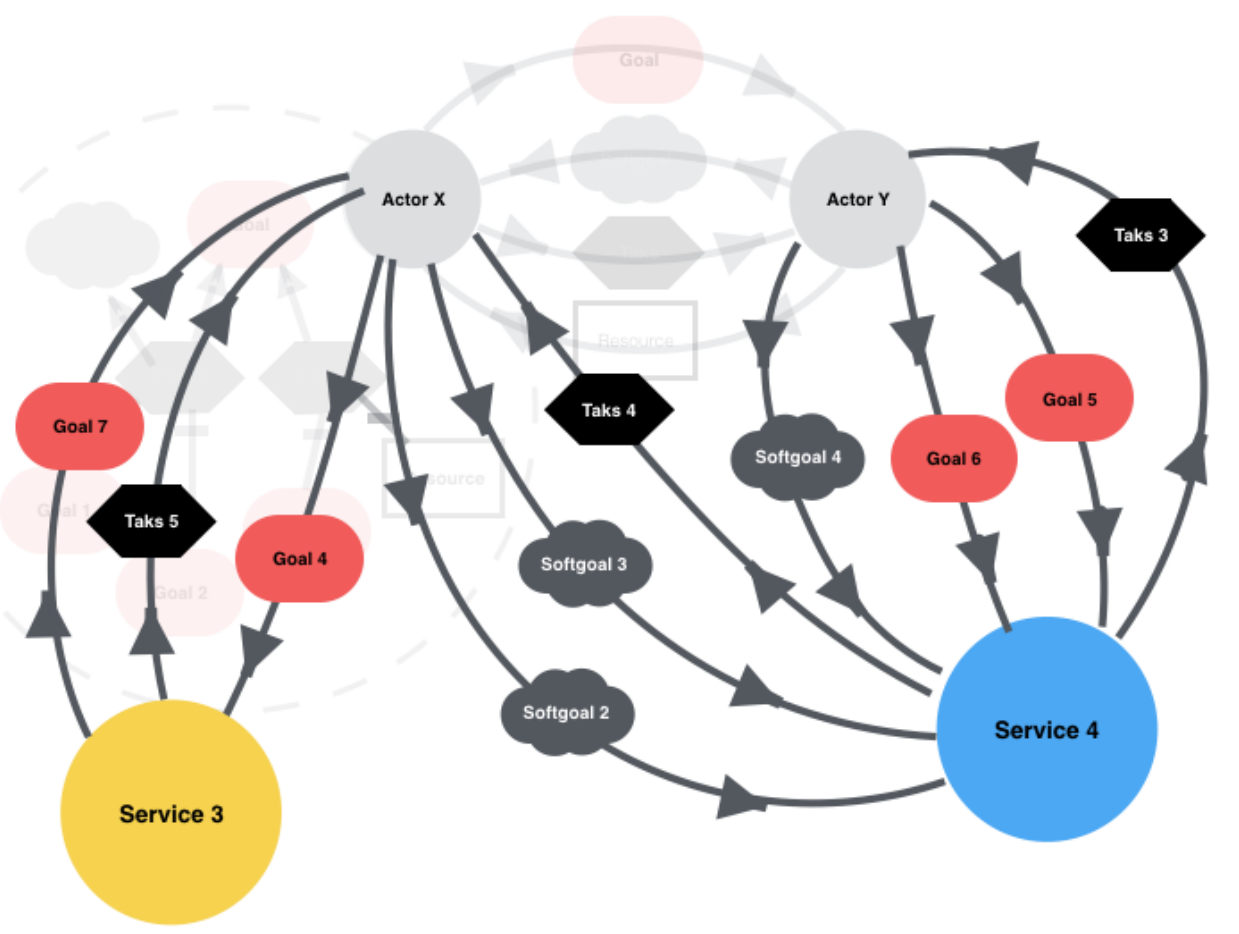

Figure 29: System-to-be model and Expectation set. Figure created by author.

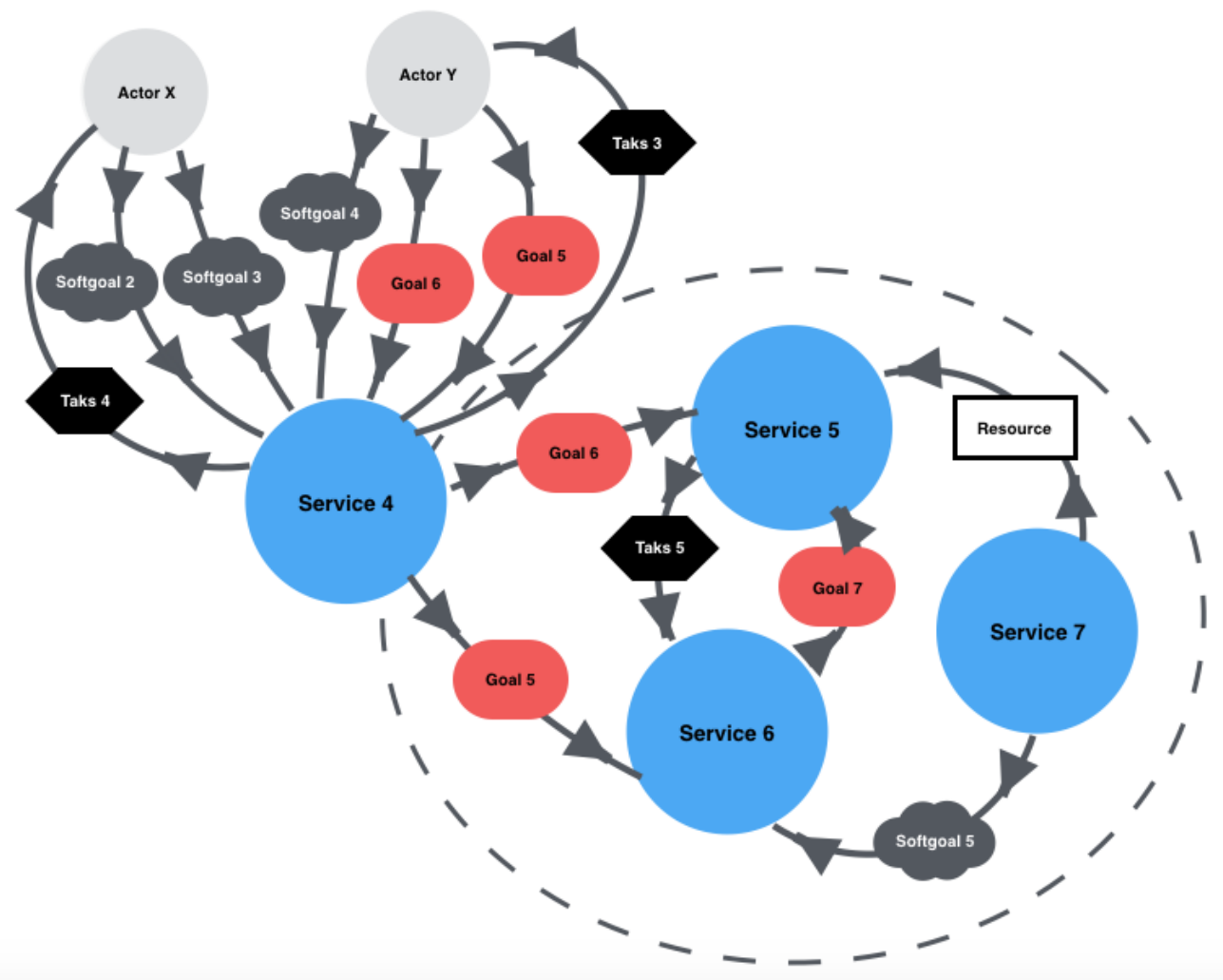

Figure 30: System-to-be model KAOS specification. Figure created by author. 
Table 5: Intentional Identification Phase Steps

\begin{tabular}{ll}
\hline \hline Steps & Sub-steps \\
\hline Expectation Modeling & (i) expectations identification \\
& (ii) viewpoint inclusion and association \\
& (iii) expectations influence relationship \\
\hline Service Component Modeling & (i) expectation clustering \\
& (ii) service generation \\
& (iii) service collapsing strategy \\
& (iv) system-to-be formation \\
\hline
\end{tabular}

\subsubsection{Intentional Identification Phase Summary}

In fact, the implementation of GORE modeling approach in the PSA Service Design Discipline has required a development of the identification phase. The Intentional Identification Phase presented concentrate the following contributions to the PSA previous Design Discipline:

- Development of both the expectation identification and service identification phases,

- Definition of the expectation and service component models, and

- Specification of both viewpoints and services collapsing strategies.

Therefore, this development, coupled with GORE propositions and techniques, enriches the PSA Service Design Discipline improving its capability to create product-service systems that can co-create value.

We summarized all steps of the Intentional Identification phase on table 5 .

\subsection{Application of the Intentional PSA Service Design Discipline}

The Intentional PSA Service Design Discipline was applied on two different contexts. The first is a reference model extracted from Sampson's article repre- 
senting a health care service system (SAMPSON, 2012). The second is a real modeling context using an industrial and manufacturing context on a multinational shoe's industry in Brazil.

We will focus on the Intentional Identification Phase as its represent a central contribution to the PSA Service Design Discipline in order to include intentional modeling to model services.

\subsubsection{Health Care Service System Design}

Extracted from (SAMPSON, 2012), Sampson models a Health Care Service System using four different viewpoints: Health Clinic, Patient, Insurance Company and Pharmacy (fig. 31).

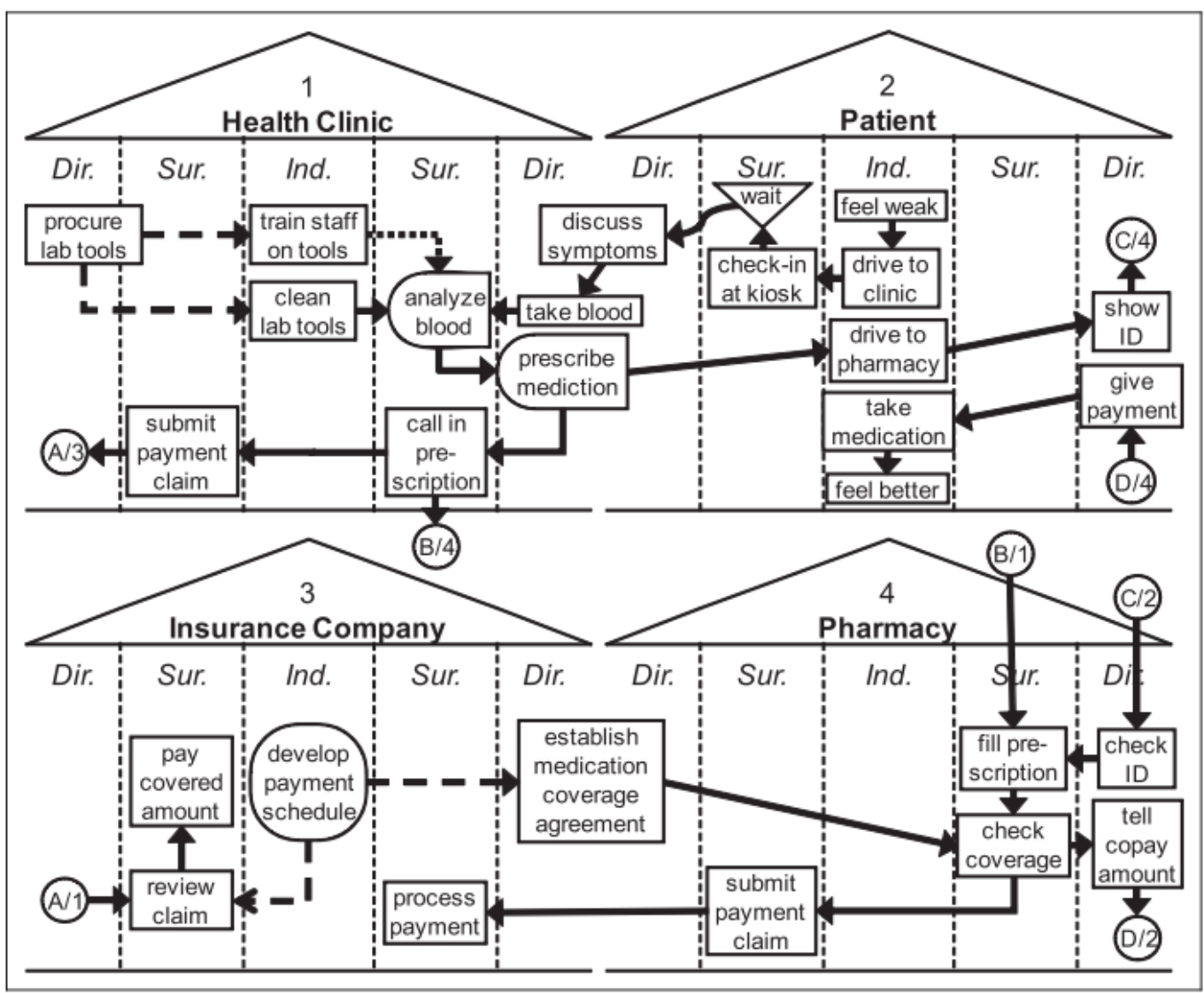

Figure 31: Sampson's Health Care System Model. Extracted from (SAMPSON, 2012). 
Sampson describes a health care system through a series of tasks (and few states) that are connected to each other and sometimes dependent of another actor's task. For example, a patient has three tasks on the interface with the health clinic: "discuss symptoms", "take blood" and "prescribe medication". Following the patient process, he will have a new interface with the pharmacy to acquire the medication. From the state "feel weak" to the state "feel better", the patient has a path through the health clinic, pharmacy, taking medication by himself. To support that chain of services, the Insurance Company, on the backstage, provide the payment flux for the whole chain of services.

Before focusing in the Intentional Identification Phase, it was necessary to transform Sampson's model on a System-as-is as defined on our Intentional PSA Service Design Discipline.

Using the ERi*c method presented by Oliveira (OLIVEIRA; LEITE, 2011) the actors' tasks were listed and transformed on goals and softgoals by a language transformation strategy that search for the "why's" and define goals using passive form tenses (see fig. 32).

For example, the task "Discuss Symptoms", using the transformation, becomes the goal "Symptoms BE Analyzed" and identifies also it actor's dependency connecting "BY Health Clinic".

Following ERi*c's method, the next phase proposes a division of the context in SDsituations. The SDsituations divides the whole relationship between the actors in situations, organizing the modeling process and simplifying the visualization of the models. For the Health Care system it was identified three SDsituations: (i) Health Clinic - Patient care, (ii) Pharmacy Service and (iii) Insurance Service.

The final organizations of goals and softgoals for the SDsituation 1 is represented by the table on fig. 33 . 


\begin{tabular}{|c|c|c|c|c|c|}
\hline \multicolumn{6}{|l|}{ Behavioral Responses } \\
\hline SYMBOL (type: Subject) & <concrete goal> & & & & actor \\
\hline - Behabioral response & <subject / object LEL> & BE & <verbs & by & esubject LEL> \\
\hline \multicolumn{6}{|l|}{ Patient } \\
\hline Feel week & ElexibleAction & & & & \\
\hline \multicolumn{6}{|l|}{ Drive to Clinic } \\
\hline BECAUSE Patient wants & Symptoms & $\mathrm{BE}$ & Analysed & by & Health Clinic \\
\hline \multicolumn{6}{|l|}{ Check-in at Kiosk } \\
\hline BECAUSE Health Clinic wants & Patient & $\mathrm{BE}$ & Screened & & \\
\hline Wait & ElexibleAction & & & & \\
\hline \multicolumn{6}{|l|}{ Discuss Symptoms } \\
\hline BECAUSE Health Clinic wants & Symptoms & $\mathrm{BE}$ & Understood & & \\
\hline BECAUSE Patient wants & Symptoms & $\mathrm{BE}$ & Diagnosed & by & Health Clinic \\
\hline \multicolumn{6}{|l|}{ Drive to Pharmacy } \\
\hline BECAUSE Patient wants & Medication & $\mathrm{BE}$ & Aquired & & \\
\hline \multicolumn{6}{|l|}{ Show ID } \\
\hline BECAUSE Pharmacy wants & Patient & $\mathrm{BE}$ & Identified & & \\
\hline \multicolumn{6}{|l|}{ Give Payment } \\
\hline BECAUSE Pharmacy wants & Amount & $\mathrm{BE}$ & Payed & by & Patient \\
\hline \multicolumn{6}{|l|}{ Take Medication } \\
\hline BECAUSE Patient wants & Symptoms & $\mathrm{BE}$ & Treated & & \\
\hline Feel Better & Elexible Action & & & & \\
\hline
\end{tabular}

Figure 32: Application of ERi*c Method to Sampon's Health Care Model: Transforming tasks on goals

\begin{tabular}{|c|c|c|c|c|c|c|}
\hline DEPENDER & & (Sdsituation) & & & & DEPEENDEE \\
\hline \multicolumn{7}{|l|}{ Patient } \\
\hline \multirow[t]{2}{*}{ quality [health] } & 1 & symptoms & $\mathrm{BE}$ & analysed & by & Health Clinic \\
\hline & 1 & blood & $\mathrm{BE}$ & analysed & by & Health Clinic \\
\hline \multirow[t]{3}{*}{ efficiency [service] } & 1 & symptoms & $\mathrm{BE}$ & diagnosed & by & Health Clinic \\
\hline & 1 & medication & $\mathrm{BE}$ & aquired & & \\
\hline & 1 & symptoms & $\mathrm{BE}$ & treated & & \\
\hline \multicolumn{7}{|l|}{ Health Clinic } \\
\hline proper [blood] & 1 & symptoms & $\mathrm{BE}$ & understood & & \\
\hline \multirow[t]{6}{*}{ accurate [tools] } & 1 & blood & $\mathrm{BE}$ & analysed & & \\
\hline & 1 & lab tools & $\mathrm{BE}$ & cleaned & & \\
\hline & 1 & lab tools & $\mathrm{BE}$ & aquired & & \\
\hline & 1 & medication & $\mathrm{BE}$ & aquired & by & Patient \\
\hline & 1 & prescription & $\mathrm{BE}$ & taken & by & Pharmacy \\
\hline & 1 & amount covered & $\mathrm{BE}$ & payed & by & Insurance Company \\
\hline
\end{tabular}

Figure 33: Application of ERi*c Method to Sampon's Health Care Model: Final goals and softgoals for the SDsituation representing Health Clinic - Patient care 
Note that each softgoal was connected to a related goal and they were transformed (following ERi*c's method) on an quality attributes in an specific format. For example, the goal "symptoms BE diagnosed" connecting patient to health clinic has an service efficiency softgoal related.

The final result is a System-as-is representing the Intentionality of the Health Clinic and Patient into a care situation (fig. 34).

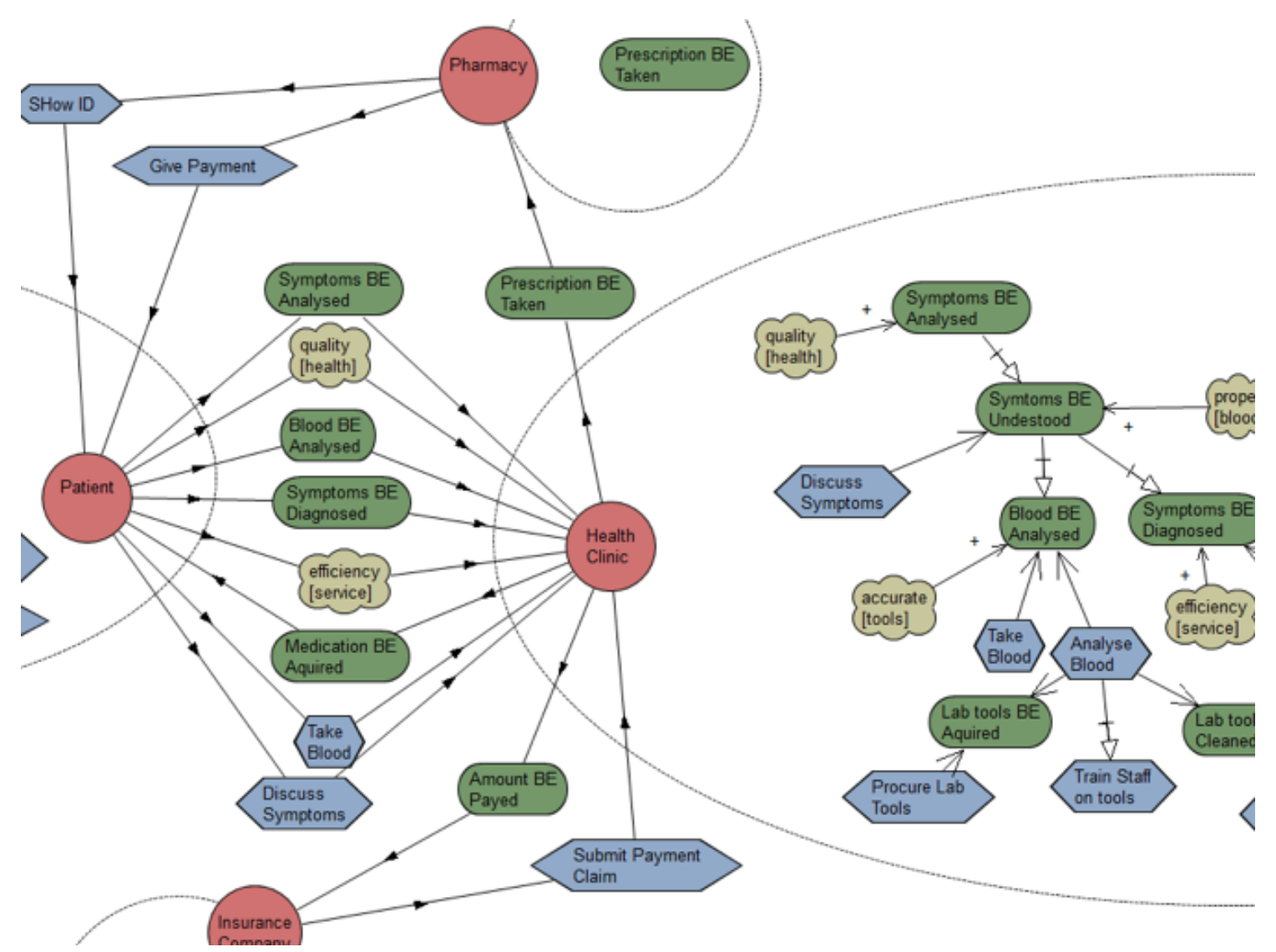

Figure 34: System-as-is for the Health Care System Model. A zoom view of internal elements. Figure created by author using TAOM4E modeling tool.

This system-as-is represent just the first SDsituation, resulting on an i* model that specify especially patient and health clinic internal and external intentionalities.

Finished the ERi* ${ }^{*}$ method to elicitate the intentions and offer a system-as-is model and following the Intentional PSA Service Design Discipline, it is time to start the Intentional Identification phase. 
For that, an expectation model should be created. As the first step, expectations identification process was conducted using the four types of heuristics: (i) Delegation/improvement of some goal (or sub-goal) execution to a new serviceproduct system, (ii) A better realization of softgoals (or sub-softgoals), (iii) A new goal/softgoal opportunity generated by a task, and (iv) A new goal/softgoal opportunity generated by new tasks opportunity related with a resource.

Following a similar process of ERi*c's method, to generate expectation we propose projections on an language transformation frame using three modal verbs expressing necessity, possibility or prediction: should BE, may BE or could BE.

The strategy is represented on table represented on fig. 35 .

\begin{tabular}{|c|c|c|c|c|c|}
\hline Expectation Identification & & & & & \\
\hline Description & Type & $\begin{array}{l}\text { Satisfaction Prob } \\
\text { (I and II) }\end{array}$ & $\begin{array}{l}\text { New Opportunity } \\
\text { (III and iV) }\end{array}$ & Projection? & Type \\
\hline \multicolumn{6}{|l|}{ Patient } \\
\hline Symtoms BE Treated & Goal & $\begin{array}{l}\text { Simple desease took } \\
\text { same cycle }\end{array}$ & & $\begin{array}{l}\text { Different Symptoms should BE directed to } \\
\text { Different treatments Clycles }\end{array}$ & Goal \\
\hline Drive to Clinic & Task & & $\begin{array}{l}\text { There are patients that } \\
\text { can't drive to the Clinic }\end{array}$ & Patients could BE treated no matter where & Goal \\
\hline Check-in at Kioski & Taks & & $\begin{array}{l}\text { Poor information aquired | } \\
\text { Poor efficiency increase }\end{array}$ & $\begin{array}{l}\text { Patients may BE Screened in a better way I } \\
\text { Efficiency [Data Aquicition] }\end{array}$ & Softgoal \\
\hline Medication BE Aquired & Goal & $\begin{array}{l}\text { Patient is tyred and has } \\
\text { to drive }\end{array}$ & & $\begin{array}{l}\text { Medication should arrive easely to patients } \\
\text { | Easely [Medication] }\end{array}$ & Softgoal \\
\hline Drive to Pharmacy & Task & & $\begin{array}{l}\text { There are patients that } \\
\text { can't drive to the Pharmacy }\end{array}$ & - & \\
\hline Show ID & Task & & - & & \\
\hline Give Payment & Task & & - & & \\
\hline Take Medication & Taks & & $\begin{array}{l}\text { Patient forget to take } \\
\text { medication }\end{array}$ & $\begin{array}{l}\text { Patient should BE warned about their } \\
\text { medication }\end{array}$ & Goal \\
\hline \multicolumn{6}{|l|}{ Health Clinic } \\
\hline Symptoms BE Analysed & Goal & $\begin{array}{l}\text { Simple desease took } \\
\text { same cycle }\end{array}$ & & $\begin{array}{l}\text { Different Symptoms should BE directed to } \\
\text { Different treatments Clycles }\end{array}$ & Goal \\
\hline Quality [Health] & Softgoal & $\begin{array}{l}\text { Improve Analysis of } \\
\text { Superfitial Symptoms }\end{array}$ & & $\begin{array}{l}\text { Superfitial Symptoms should BE taken } \\
\text { before patient get to the clinic }\end{array}$ & Goal \\
\hline Symptoms BE Understood & Goal & Needs more doctors & & $\begin{array}{l}\text { Doctors may } B E \text { able to care no matter } \\
\text { where }\end{array}$ & Goal \\
\hline Proper [Blood] & Softgoal & $\begin{array}{l}\text { Improve types and } \\
\text { Exams choices }\end{array}$ & & $\begin{array}{l}\text { Further investigation should BE optimed I } \\
\text { Efficiency [Diagnosis search] }\end{array}$ & Softgoal \\
\hline \multirow[t]{2}{*}{ Discuss Symptoms } & Task & & $\begin{array}{l}\text { Misunderstanding } \\
\text { nmblems }\end{array}$ & $\begin{array}{l}\text { Patient should BE teached how to } \\
\text { understand svmtoms nronerlv } \perp \text { Proner }\end{array}$ & Softgoal \\
\hline & & & & $\begin{array}{l}\text { Patient and Doctors should BE able to } \\
\text { explain clearly | Clarity [Dialog] }\end{array}$ & Softgoal \\
\hline Blood BE Analysed & Goal & $\begin{array}{l}\text { Took so much time to } \\
\text { get results }\end{array}$ & & $\begin{array}{l}\text { Results should BE instantaneous | Efficiency } \\
\text { [Blood Test] }\end{array}$ & Softgoal \\
\hline
\end{tabular}

Figure 35: Expectation Identification Process

For example, the softgoal identified as a health quality attribute for the patient could have a satisfaction problem related to a poor identification of super- 
ficial symptoms as the patient arrives on the clinic due to time constraint on screening. Using a should BE modal verb it was identified an expectation related to gather those superficial symptoms before patient arrivals resulting on a better identification, made with enough time, and accelerating screening as the patient arrives.

Following the discipline, those intentions projections are, therefore, represented on an space of opportunity model relating a set of goals and softgoals dependencies with a space that will be filled, on the future, by the system-to-be (fig. 36).

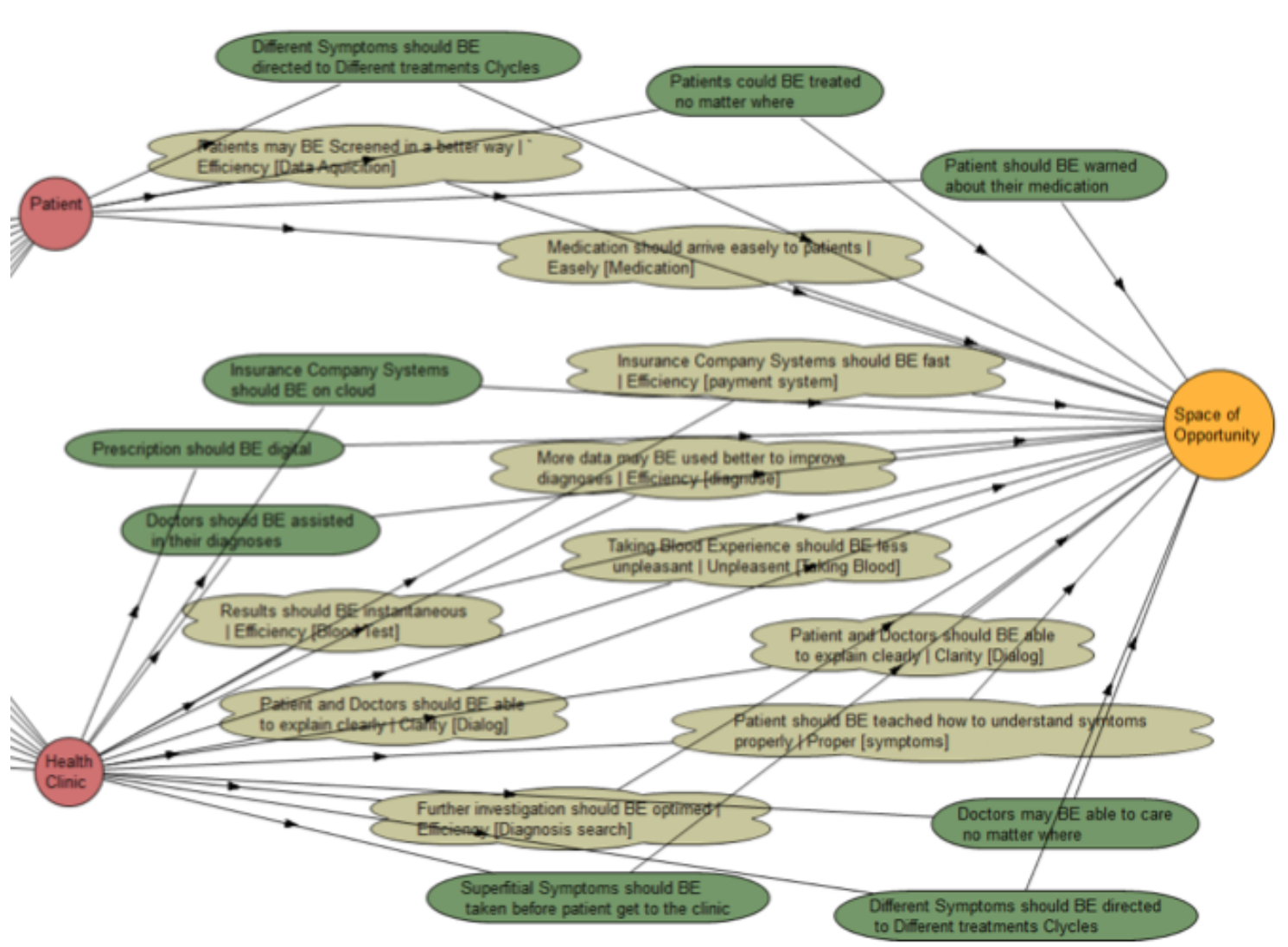

Figure 36: Expectations over an Space of Opportunity. A zoom visualization of the model

Note that the space of opportunity do not define the system (or systems) that will be used to satisfy the expectations. At this moment, it is just a graphical representation on the intentionality language that represent a design space to be 
explored. The following steps that will define how to explore this space through the service design lens.

Following the discipline, the expectations pass to a different Model where they will be treated on a more independent way in order to transform those intention's projections on service systems proposals . This model allows expectations treatments and creates the base for the generation of the first set of services (fig. $37)$.

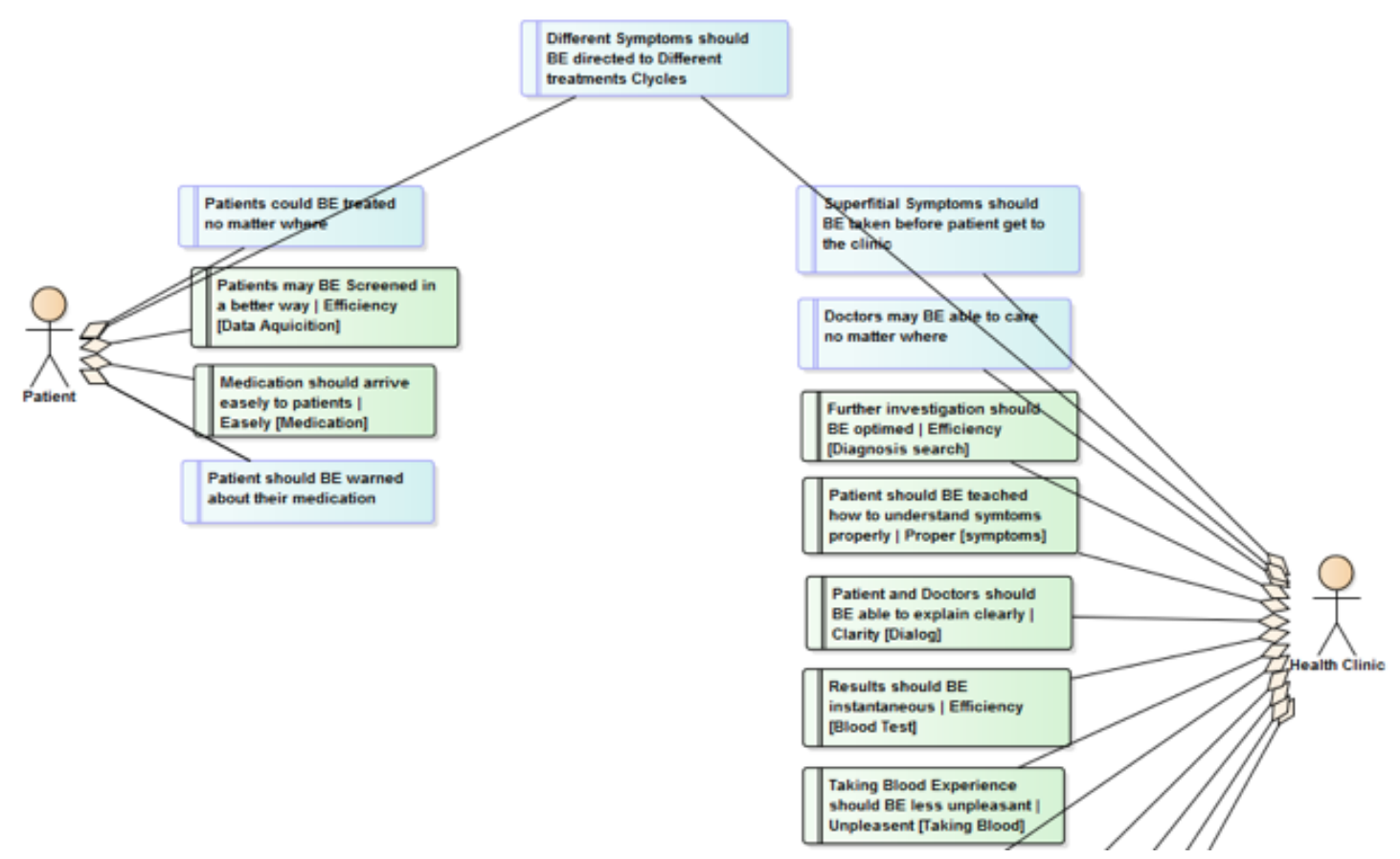

Figure 37: Expectations Model of Health Care System. A zoom visualization of the model.

From that model, an Influence matrix is generated and both positive, negative and neutral influences are qualified for each pair of expectations. The fig 38 represent the relationship matrix used on Enterprise Architect design software to represent the positive influence matrix. To apply the methodology we changed the meaning of some current elements on UML and SOMF modeling packages on Enterprise Architect. As a future work it is possible to create an specific modeling proposal on EA using the MDG module. 


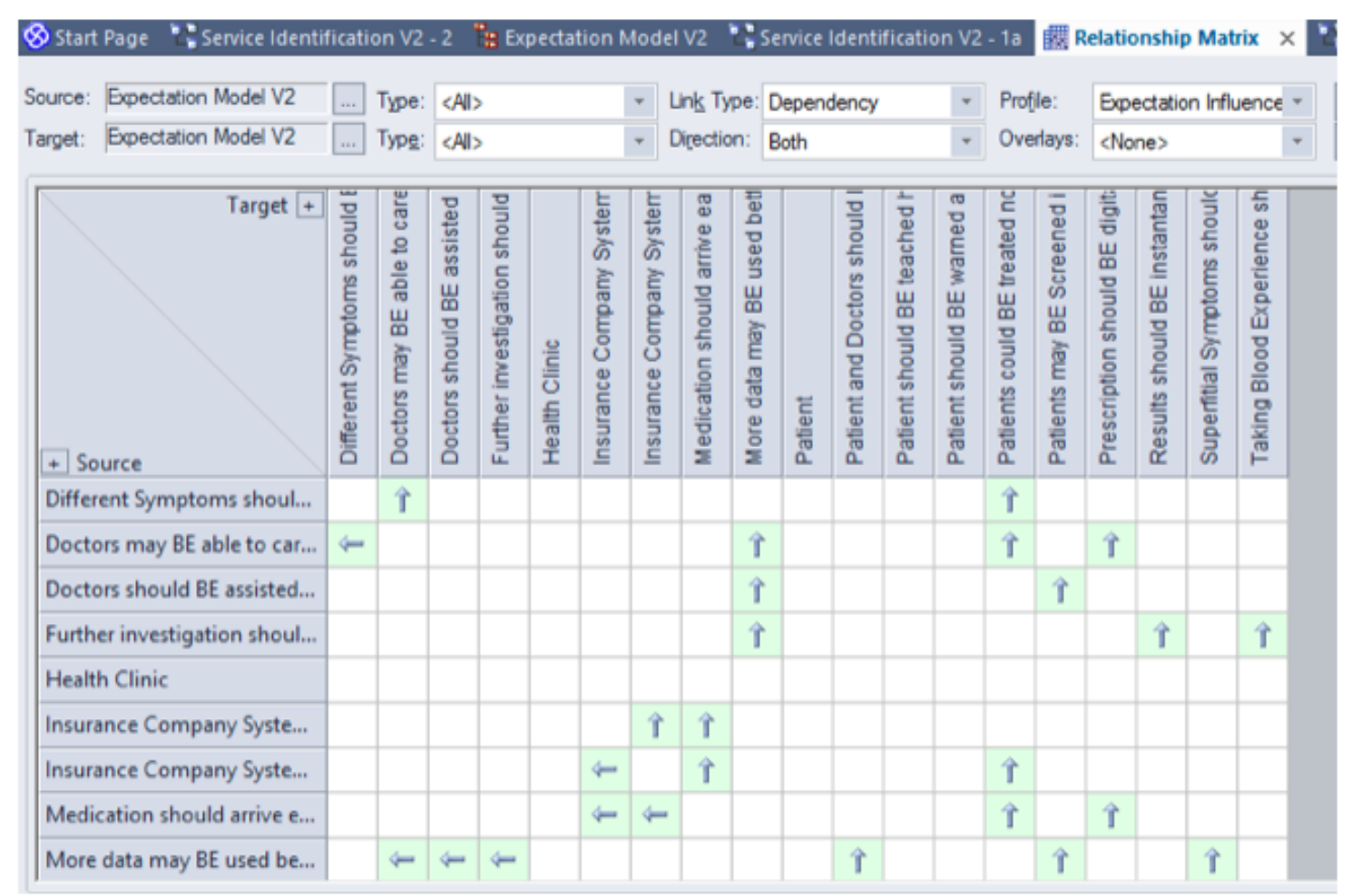

Figure 38: Positive Influence Matrix

After the set of influences between expectations the next phase is the expectation clustering. For models where there are lots of connections, the clustering strategy has to take Clustering Circuits method. A positive influence circuit is identified between three expectation elements. Each three elements that represent a circuit form a cluster. Elements that do not form a circuit remains on the previous clustering method connecting to just one expectation element on a circuit (fig. 39).

For the Health care System we applied the Expectation Clustering method and founded 11 different clusters. For every cluster (in a positive chain), a service proposition was generated arriving on a Service Generation Model composed by 11 services.

On fig. 40 a example of cluster and it respective generated service is represented for the Health Care System case. In fact, the service "Virtual Payment 


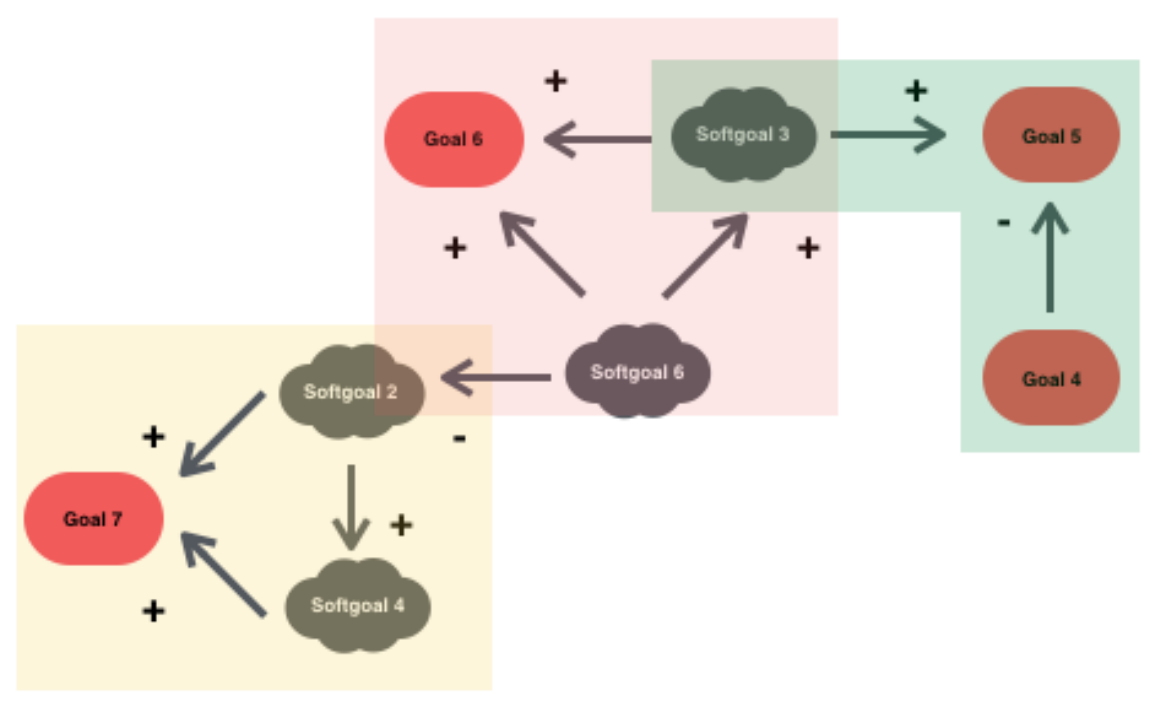

Figure 39: Clustering Circuits Strategy

Service on Cloud for Insurance Company to their partners" was generated from the cluster formed by three expectations with positive influence on a circuit: (i) Insurance Company Systems should BE fast | Efficiency (payment system), (ii) Medication should arrive easily to patients | Easily (medication), and (iii) Insurance Company Systems should be on cloud.

As a following step, the service collapsing strategy gains also a complexity due to the numbers of services (variables) and their negative influence relationship. The optimization process using the patient viewpoint will force a specific collapsing strategy that will merge the services S5, S6, S9, S10 and S11 (fig. 41).

For the Health care system, that final merging resulted on the following service: Virtual Service Marketplace to Aggregate distributed Health Care Services and Matching them to Customers (see fig. 42).

Also, the resulting of collapsing the others set of remaining services resulted on other two Service Systems: (i) Service Aggregation Platform and gadgets to improve self symptoms Perceptions and Health data collection, and (ii) PSA Cloud Service for Intelligent and Instantaneous Exams Systems. 


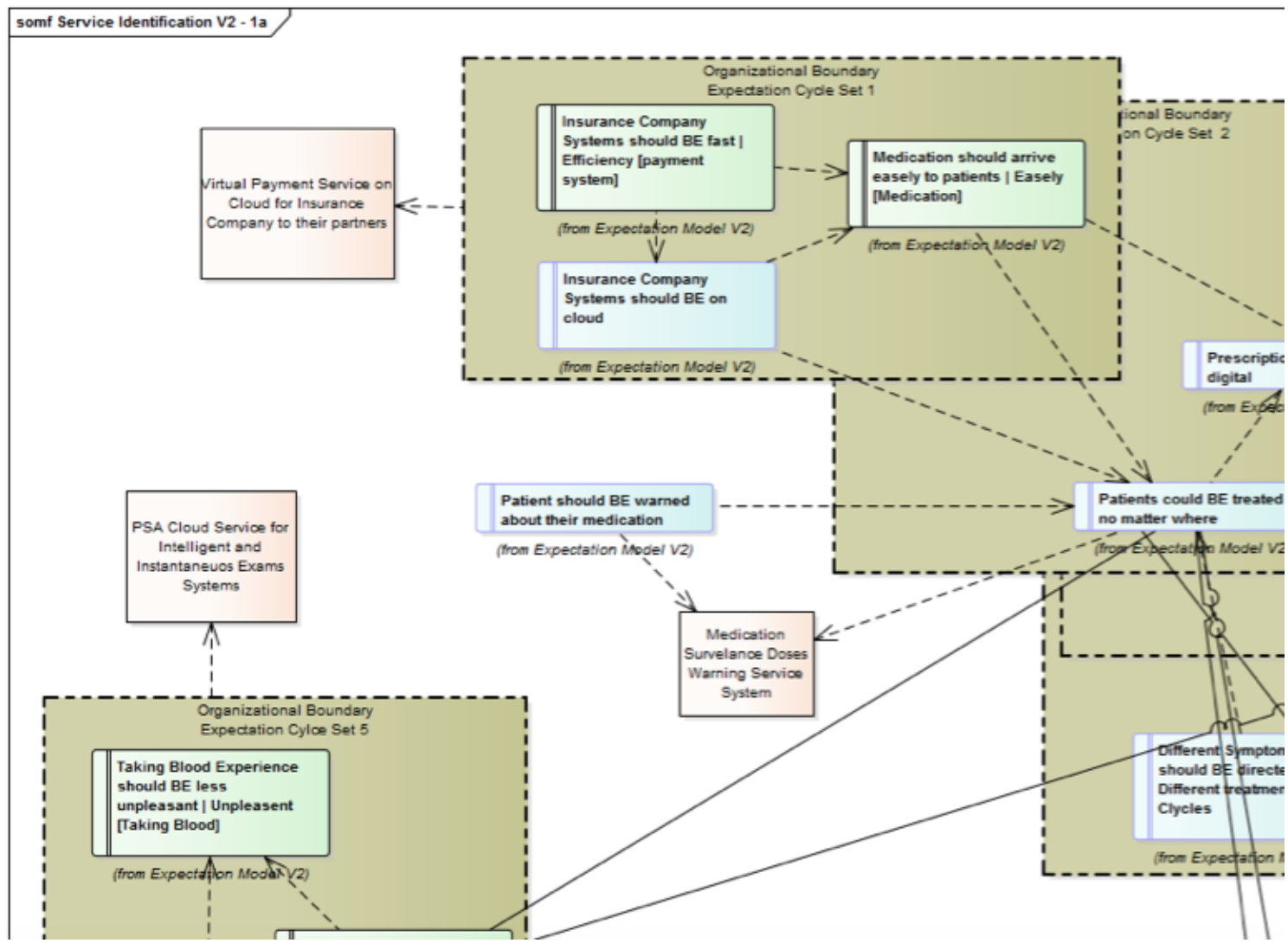

Figure 40: Service generation Model. A zoom visualization of the model. 


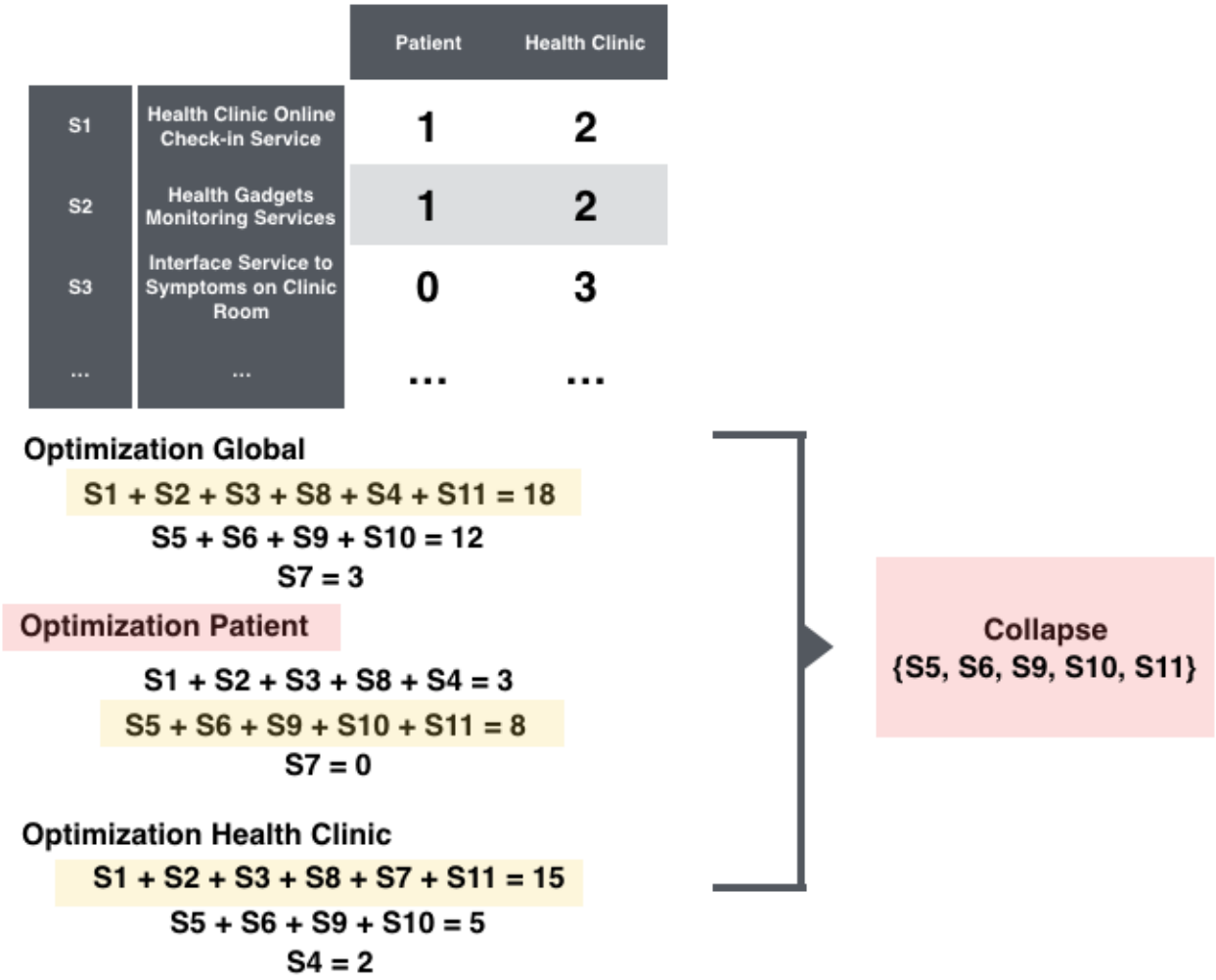

Figure 41: Collapsing Strategy for Health Care System

At this point, we converged to a System-to-be and we can return to the Goaloriented modeling structure and relocate the Space of Opportunity into our new System-to-be (fig. 43).

From that on an KAOS modeling strategy follows in order to finish the Intentional PSA Service Design Discipline (fig. 44). On a first attempt six sub-services were proposed to implement the system-to-be: (i) Service Diagnosis System, (ii) Virtual Health Care System with Online Conference Calls with Doctors, (iii) Health Clinics Networked Systems applied also to conference with online doctors, (iv) Insurance payment Service System, (v) Pharmacy Delivery Medications Service, and (vi) Medication monitor service system.

Therefore, the Intentional Service Identification Phase, based on the intentions elicited by ERi*c method, could bring expectations on analysis and generated service system proposals that could offer a system-to-be that would satisfy 


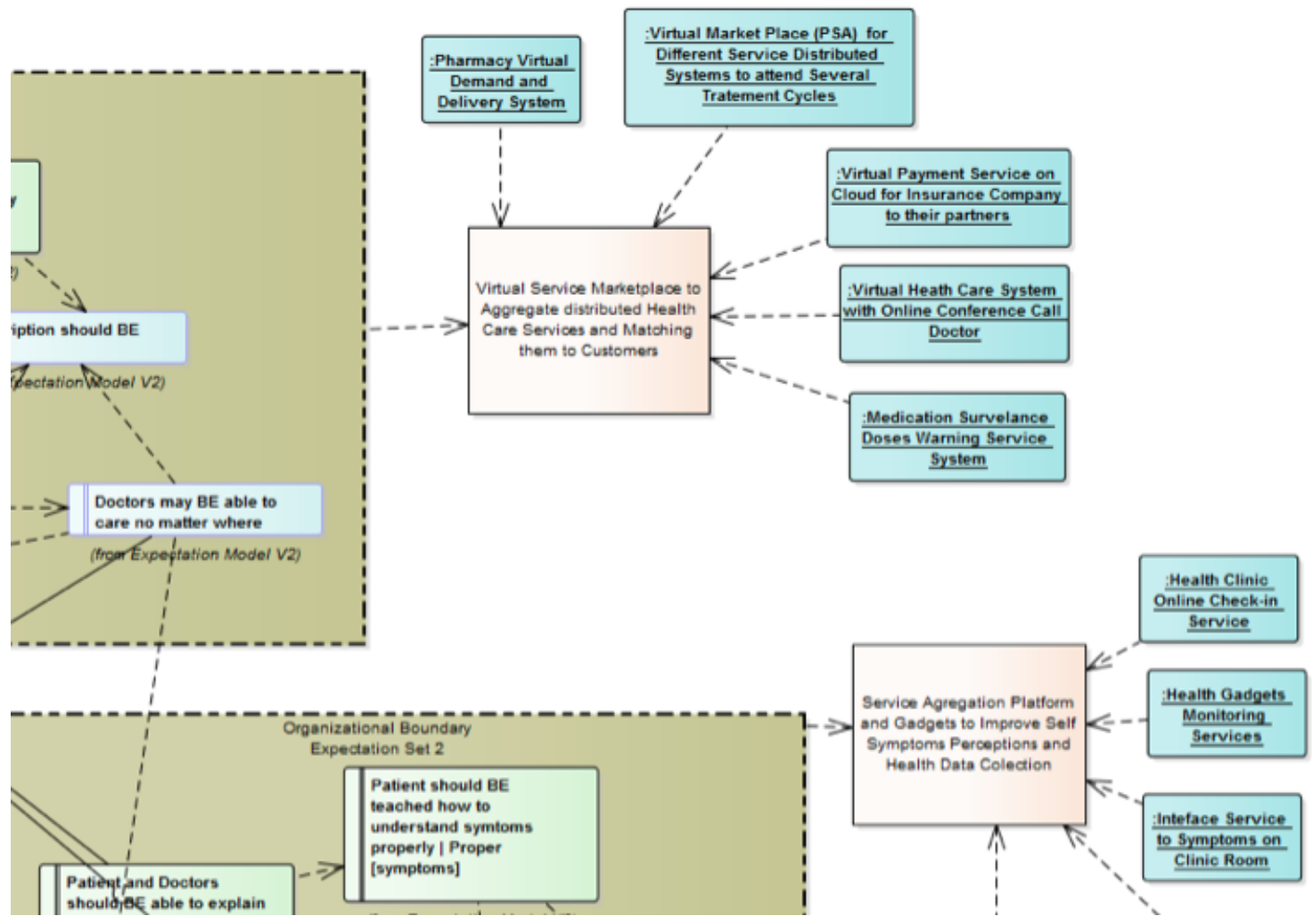

Figure 42: Final Services after Collapsing Strategy. A zoom visualization of the model. 


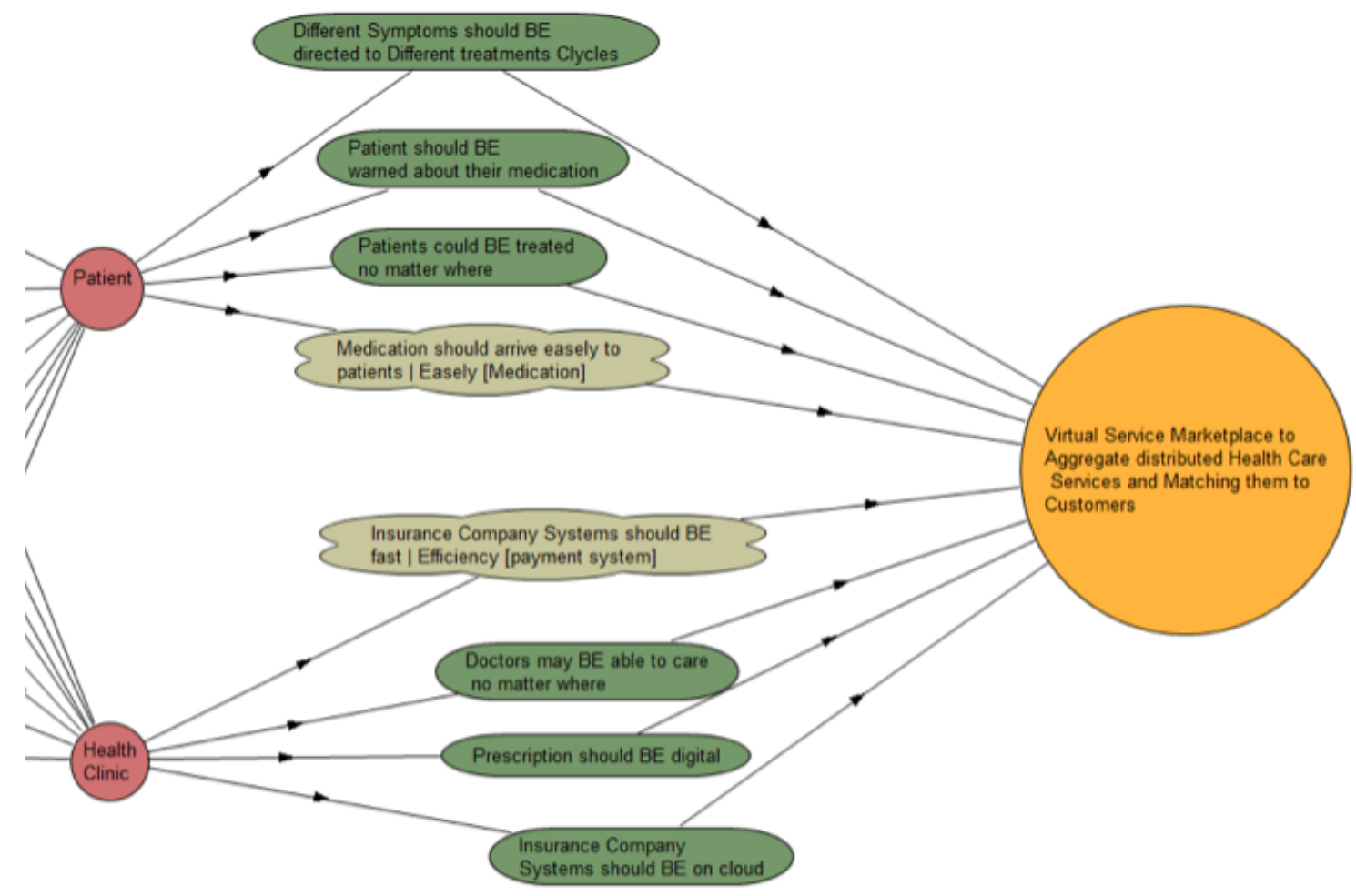

Figure 43: First System-to-be allocation. A zoom view on expectation.

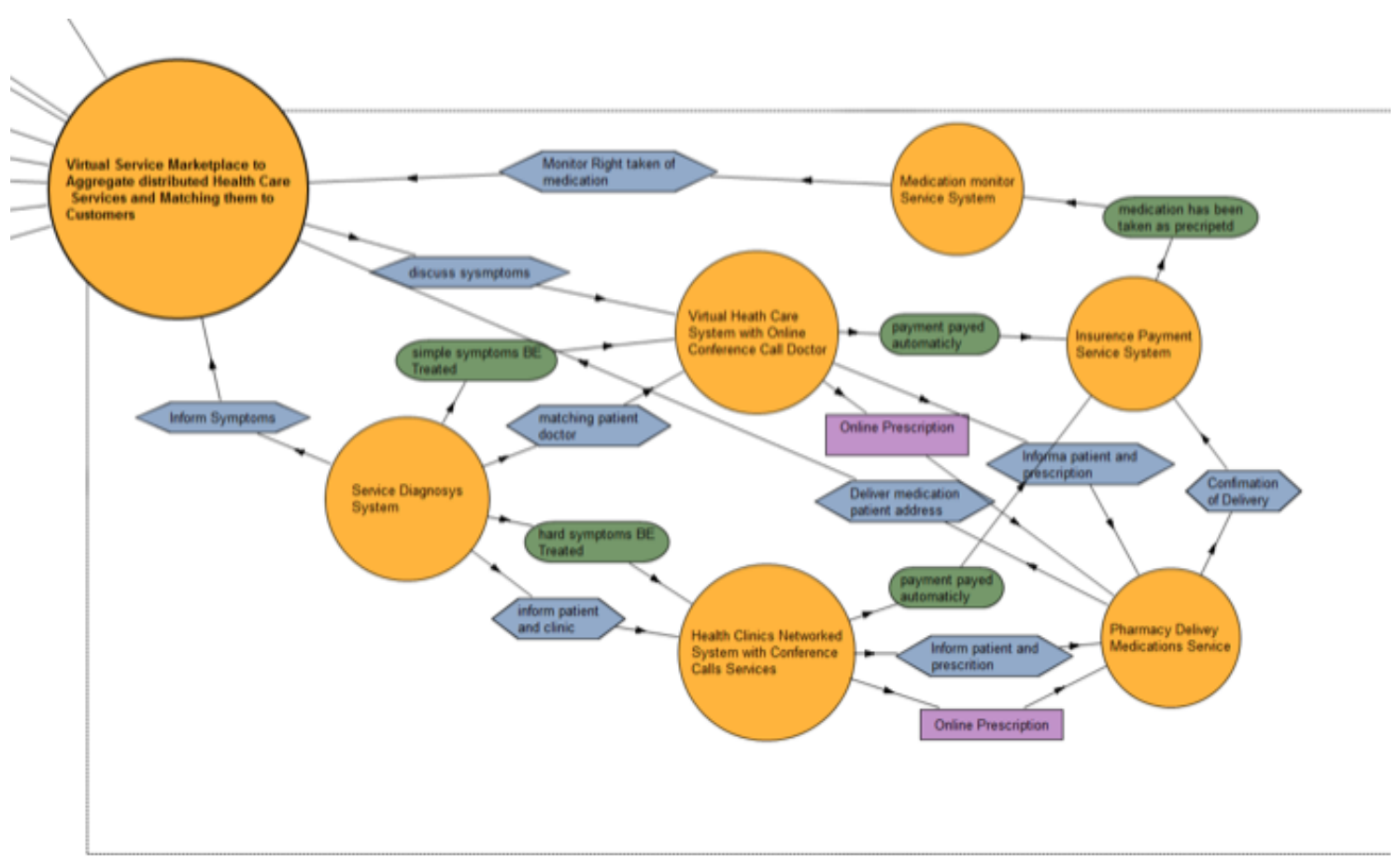

Figure 44: First KAOS modeling on System-to-be 
better the intentions. That part of the Intentional PSA Service Design Discipline adds an logical process to generate service systems maintaining the intentional aspect from the beginning to the end of the Design Cycle.

\subsubsection{Case Study: Manufacturing Industry System}

The application of the Intentional PSA Service Design System to a Manufacturing Service represents the proposal model for a manufacturing system to run as an manufacturing service. In fact, even it is known that service paradigm is impacting all economic sectors, for manufacturing industries, operating as a service demands a review not just of its customer relationship but also its production strategy as well.

The PSA architecture offers a frame that allows the uncoupling of a production chain into series of independent service systems that co-produces according to a service provider plan associated to a costumer demanding for a service (or a product-service).

As a case study for the Intentional PSA Service Design Discipline, we choose a real case at a big manufacturing company in Brazil. It is a big company on fashion business with a core technology on plastic injection. We are going to model the design of a new female product line where we have the interaction of three main actors: Business Management, Design Management and Mold Manufacturing departments.

The expected result is the consolidation of a cloud of service-product systems that could be organized on a plan since a service provider demands a new productservice to be operated. As the scope of this work is not the discussion of the implementation of such new system, we are not going into that matter, leaving a PSA implementation strategy into manufacturing industries to future works. 


\subsubsection{Intention Service Identification Phase}

To structure the system-as-is we used the same strategy used on the last example with ERi*c method. However, in the last example, Sampson offers an activity flux between actors. On this example we did not use Sampson's frameworks, however, we asked on a conducted interview for the stakeholder to list the activities of each stakeholder on the context of the design of a new female product line. The fig. 45 show the list produced by the stakeholder.

\begin{tabular}{|c|c|c|}
\hline \multicolumn{3}{|l|}{ Actors Taks and Resources } \\
\hline $\begin{array}{l}\text { Business Management } \\
\text { (female line) }\end{array}$ & Design Management (female line) & Mold Manufacturing \\
\hline Analyze market demand & Do a Cool Hunting Study & Evaluates Demand \\
\hline Evaluates competition & Drawing Model & Prepare the mockup design \\
\hline Do a Cool Hunting Study & First Design Prototype & 3D Printing \\
\hline Sets Product Strategy & Validates Cost & Do the Chock Test \\
\hline \multirow[t]{7}{*}{ Initial Approval } & Sets Blueprint & Validates with Design Management \\
\hline & Forwards Project to Mold & Mold Design \\
\hline & Chock Test Adjust & Evaluate volume to be produced \\
\hline & & Sets the number of Matrix to be produced \\
\hline & & Develops Tooling \\
\hline & & Forwards Mold and Tooling to factories \\
\hline & & Emits final approval document \\
\hline
\end{tabular}

Figure 45: List of tasks of the stakeholders on the context

Generally, the Business Management department research and analyses the market demand, statistics, market-share and fashion trends to propose a new female product line. It sets a product line strategy with the Design Management that, after approval, creates the first design concepts for the product line based on the trend studies. After some technical specification, it sends the project to 
the Mold manufacturing department that has the objective of create all molds to the entire product line. After the design and rapid prototyping techniques several validations process are conducted, including a chock test with few chosen people. Some adjustment are made with the Design Management department and after Business Management validation, the Mold Manufacturing Department produce the molds. It manufactures the number of molds necessary to produce the predicted volume of final products and sends them to the specific factories.

Following the $\mathrm{ERi}^{*} \mathrm{c}$ method presented before, the actors' tasks will be transformed on goals and softgoals by the language transformation strategy shown on the Health Care System example.

The SDsituations were organized on three steps: (i) Female Product Line Design, (ii) Mold Production, and (iii) Production Planing. As we want to understand the impacts of a PSA on a product-service situation we chosen Mold Production as the SDsituation to be modeled. The final system-as-is is shown on fig. 46.

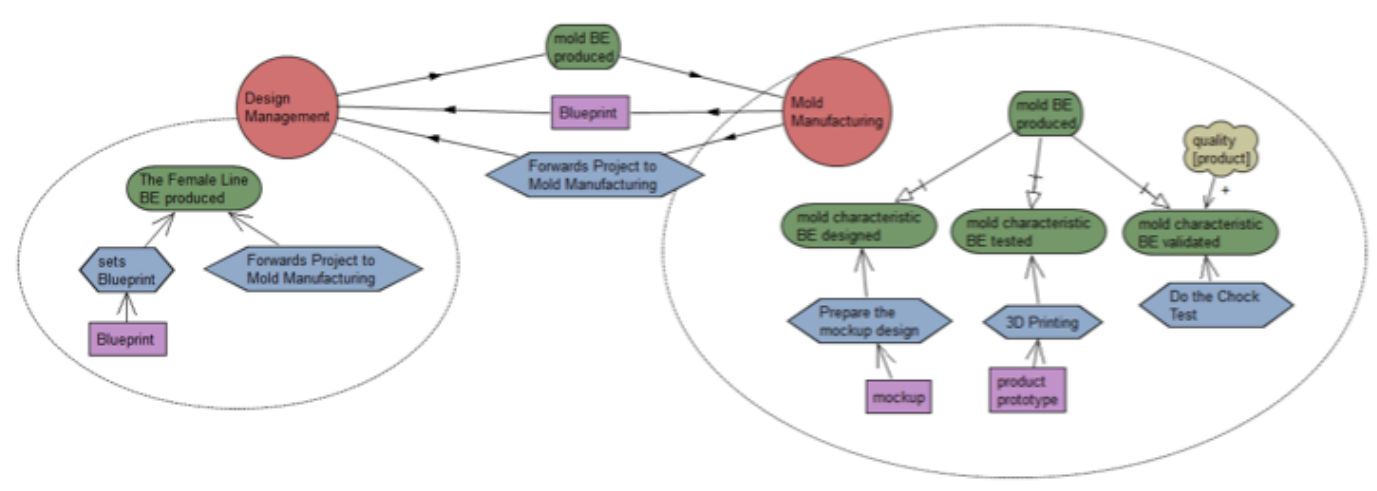

Figure 46: Mold Production System-as-is

The projection of intentions on an space of opportunity starts on an heuristics analysis of the intentions in four dimensions related to goals/softgoals satisfac- 
tions and new opportunity based on the analysis of each intentional element.

With a construction based on a language transformation using modal verbs the expectations are generated and created as a dependency between the actors to the space of opportunity. The fig. 47 represent the expectation identification model that are generated by a projection of the intention on a space of opportunity.

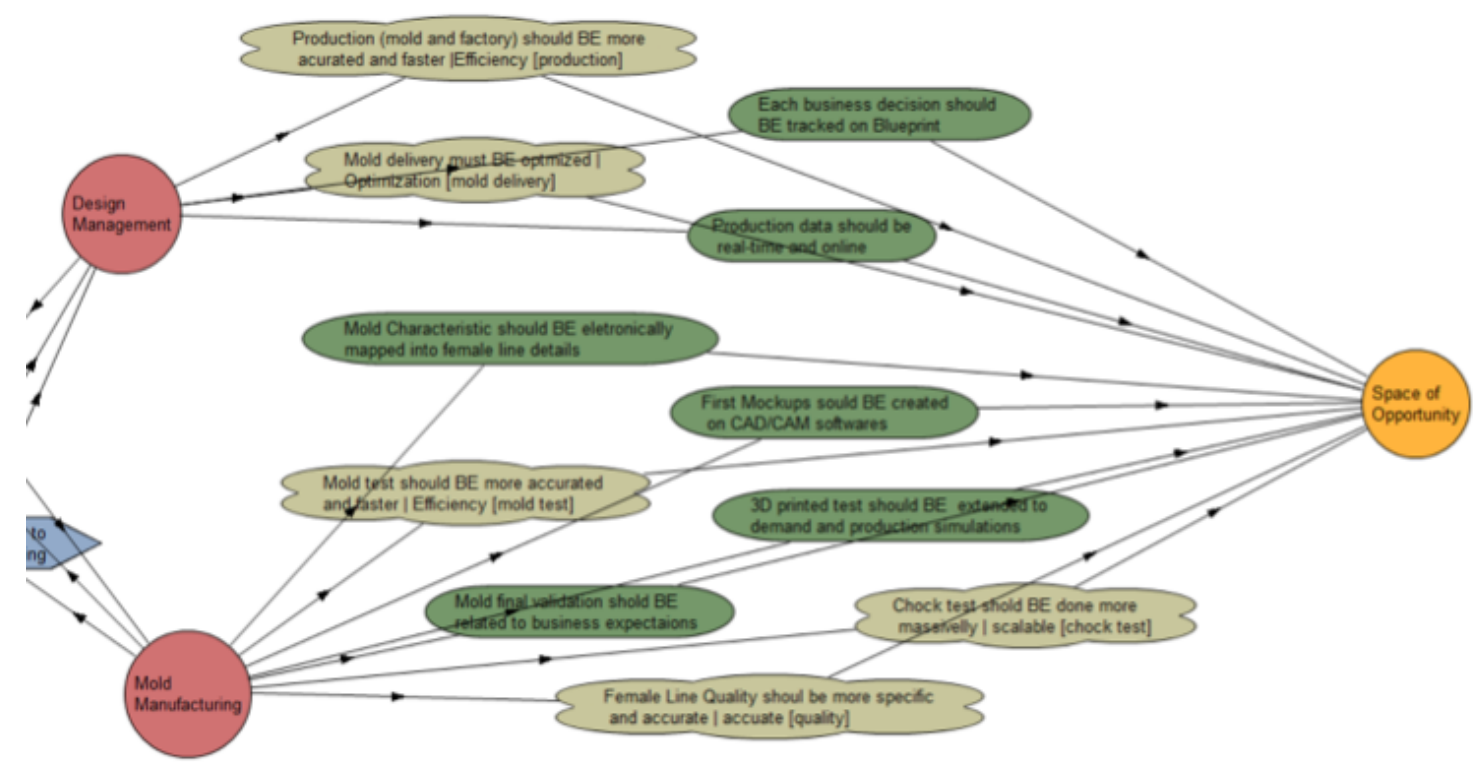

Figure 47: Intention projection over an Space of Opportunity. A zoom visualization to capture only the expectations.

An expectation generated for example is "Each business decision should BE tracked on Blueprint" meaning that the technical document to mold design should have also clear connections with the business rationale. That means that if the Mold Manufacturing changes any specification it could be tracked and measure it impact on a business decision.

On another hand, the softgoal "Female Line Quality should BE more specific and accurate | accurate (quality)" means an expectation of a system that allows for a test people perception about the product quality, their value perception 
about the almost-launched product.

From that model, the expectation identification phase uses an influence matrix to evaluate the positive, negative and neutral influences between expectations. After the evaluation, the Expectation Model for our manufacturing case is represent on a Expectation Identification Model (fig. 48).

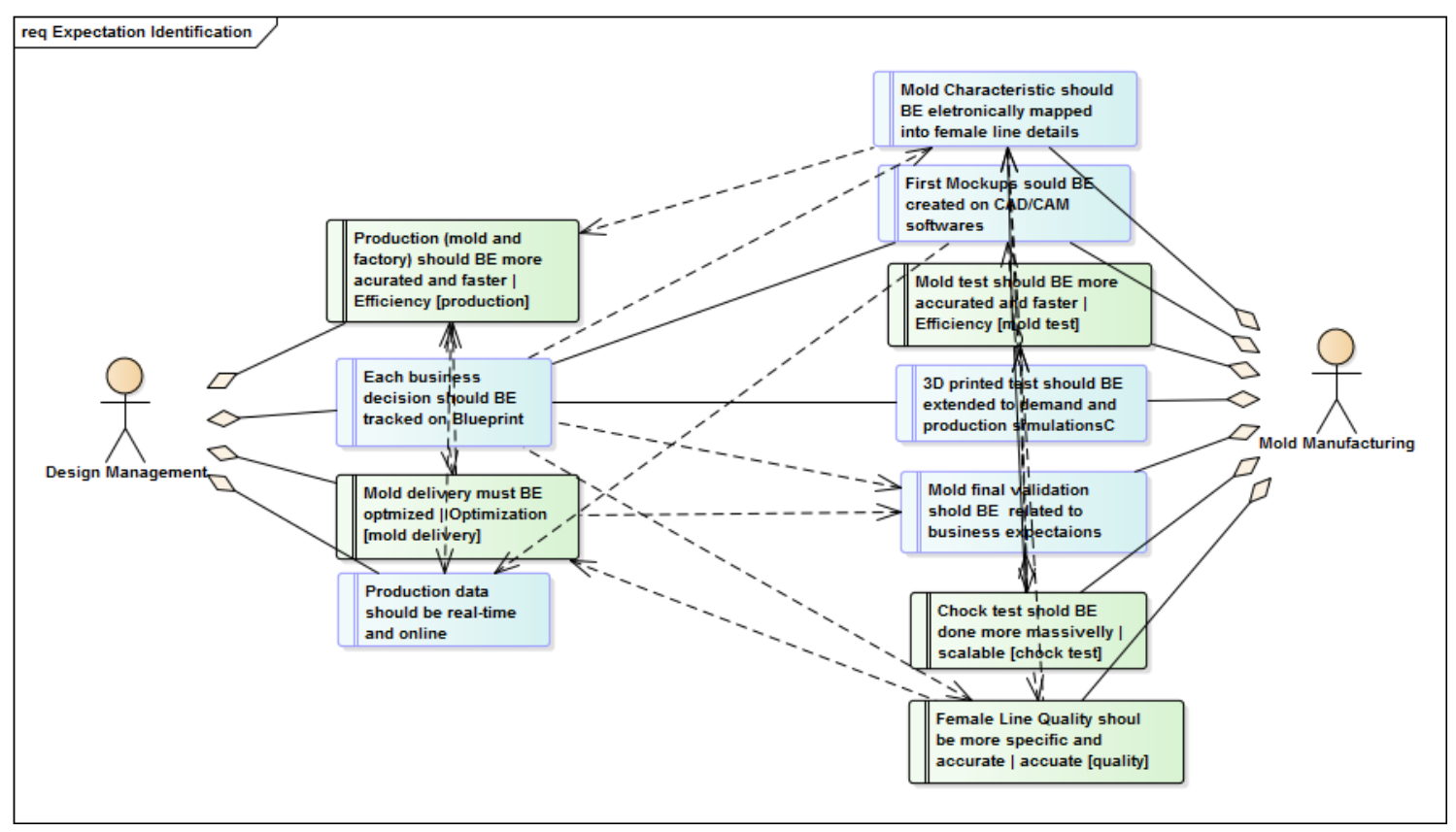

Figure 48: Expectation Identification Model

The Service Identification phase start with a the clustering strategy based on the expectation circuits. Each reinforcement circuit formed a cluster and each cluster generated an associated service (fig. 49).

For example, the service "Service Software System that map Intangible and Characteristics on Design and quality level of Female Lines" was generated from the circuit formed by three following expectations: (i) Female Line Quality should be more specific and accurate | accurate (quality), (ii) Mold delivery must be optimized | optimization (mold delivery), and (iii) Each business decision should BE tracked on blueprint.

In fact, this service has as principle the idea of supporting mapping of Female 


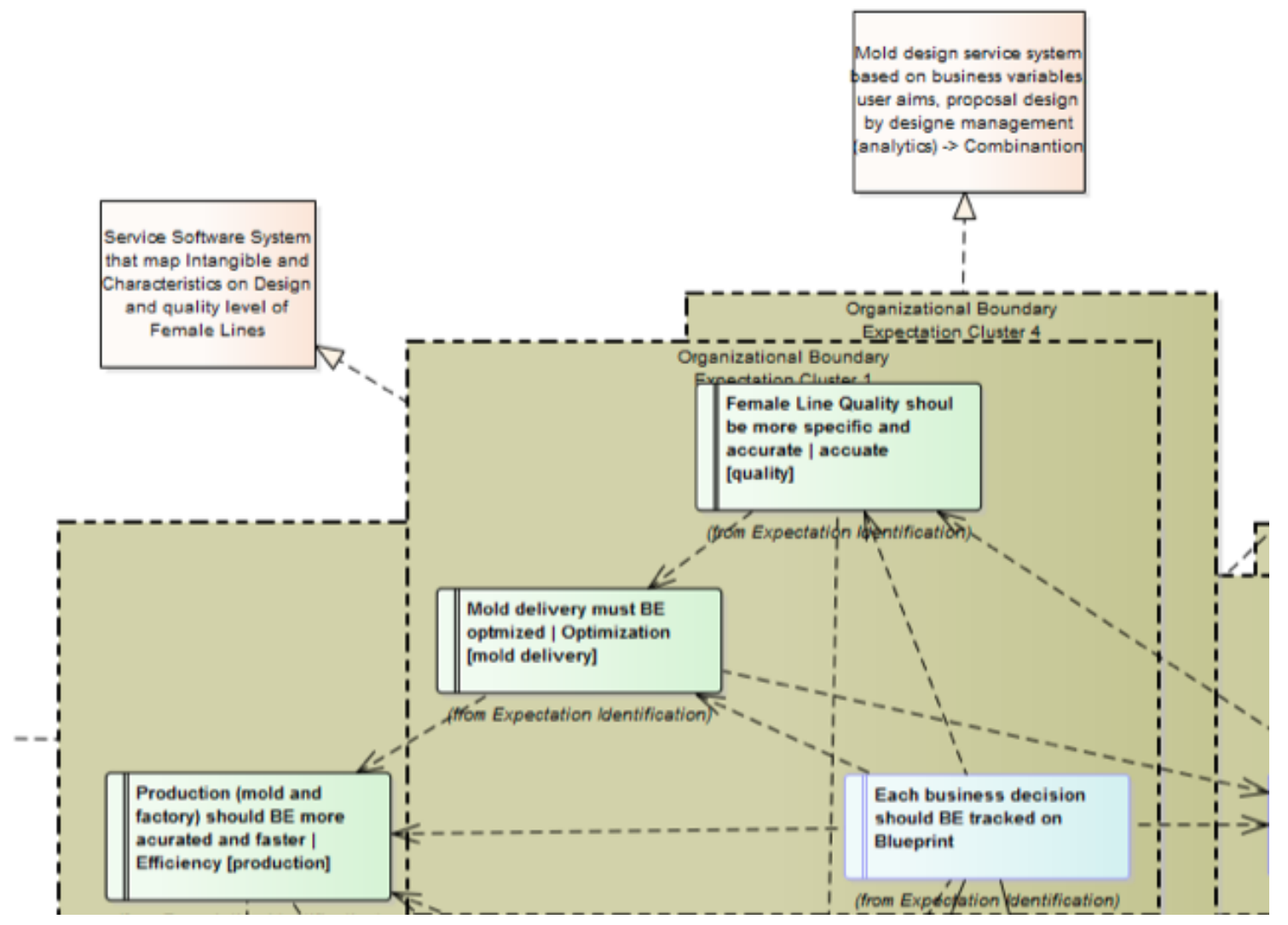

Figure 49: Service Identification Model. A zoom visualization of the model. 
Product Line characteristics into several product design characteristic and also to mold characteristics. It could be a semi-automatized service systems using the historical of projects to suggest product and mold designs. However, on that phase we do not determine how the service will operate.

We've generated 7 services that passed through the Service Collapsing Strategy. We choose the Mold Manufacturing viewpoint as the optimization pivot because we would like to explore better the impacts of the PSA on the department were a product-service can be delivered. In the end of the collapsing strategy we've arrived on two service systems (fig. 50).

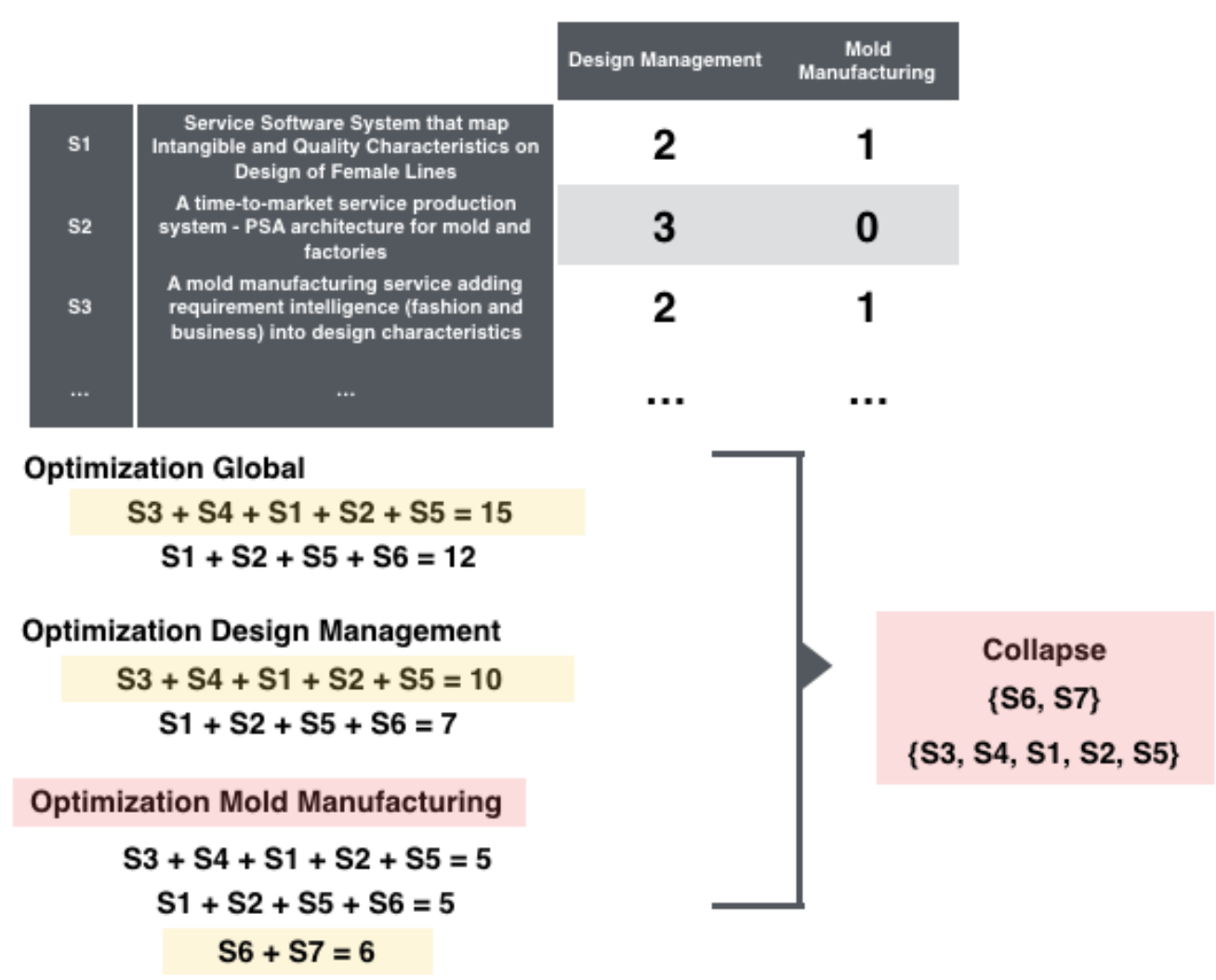

Figure 50: Service Collapsing Strategy

The collapsed main service to attend the maximum number of expectations of the Mold Manufacturing department resultant was "PSA Mold Manufacturing and Validation Service System". This is a product-service system that supports for rapid prototyping and validation. The PSA structure is necessary to define 
the combination of people and machines to deliver a service (fig. 51).

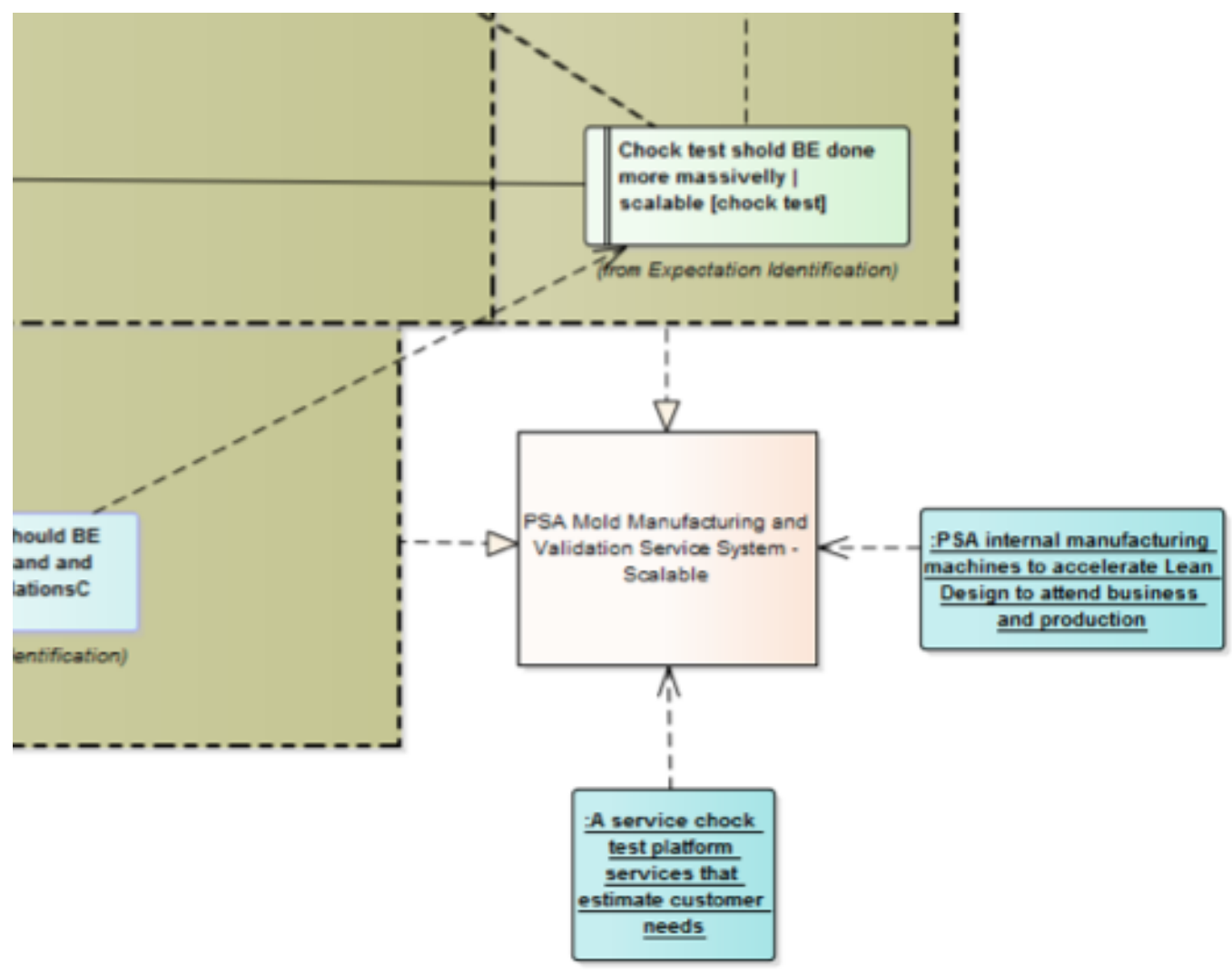

Figure 51: Service that optimize mold manufacture expectations. A zoom visualization of the model.

Following the Intentional Identification phase the last step is a return into a goal modeling bringing the chosen service as a System-to-be to satisfy the stakeholders expectations. After that, the service specification follow a KAOS methodology path. This system-to-be was divided into 7 sub-services that are responsible to, as a whole, satisfy the expectations (fig. 52).

The whole system proposes three different service interfaces with business management, design management and production. The service design core is based on a CAD/CAM design system. An validation service system is connected where 3D printing and other rapid prototyping product-services systems achieve a better product quality. Several customer validations propositions also participate in this system. An interface to customer is necessary to understand needs 


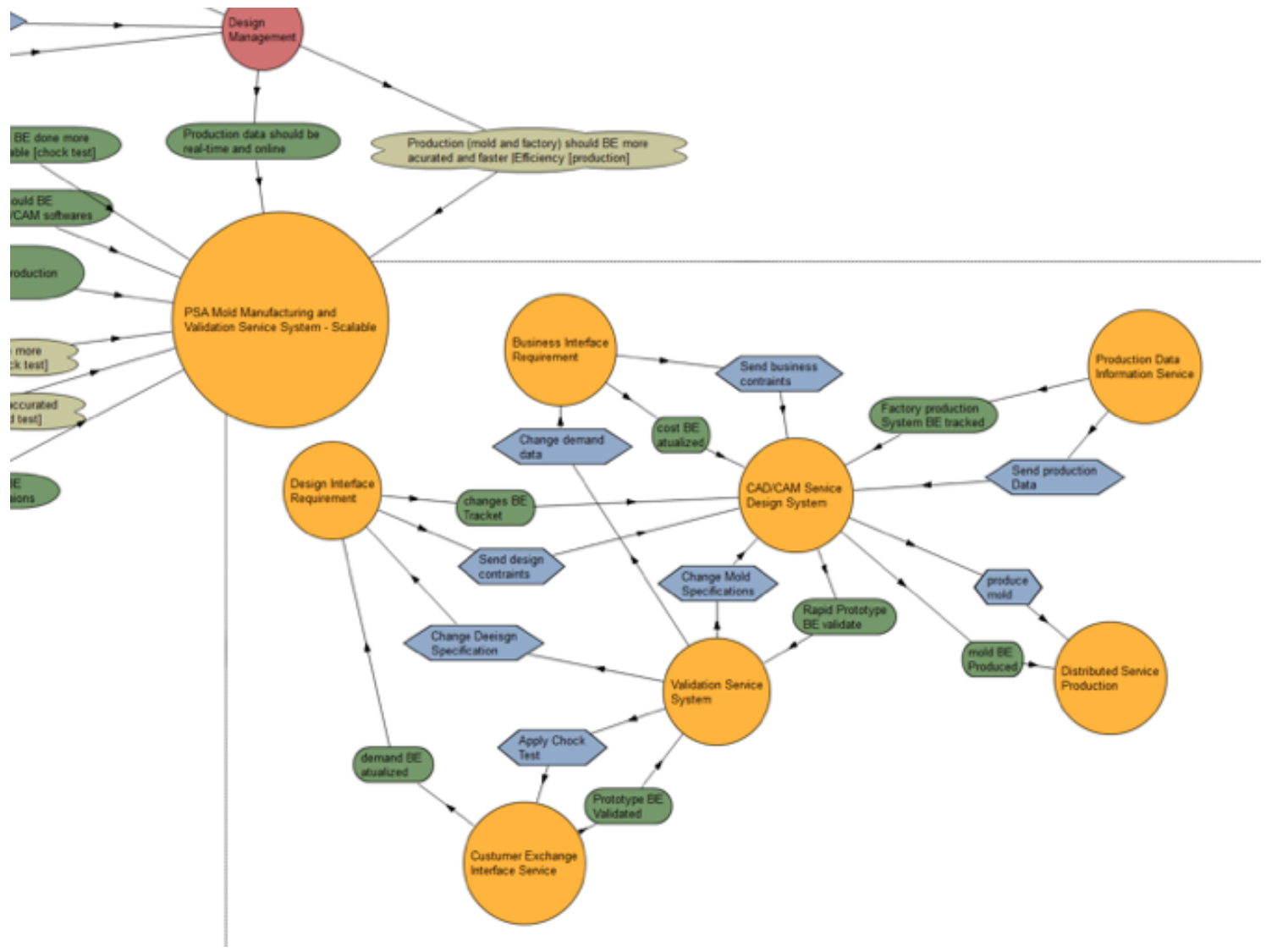

Figure 52: First KAOS System-to-be Model. A zoom visualization of the model. 
and demands. In the end, an decentralized service productions allows a production anywhere mold production machines could replicates the numerical project design. That characteristic allows for a uncoupling of the Mold manufacturing from the whole structure of the company.

In fact, this department could improve their quality and delivery with an autonomy of investment and may be offering Mold services to others industries. This could decrease costs and accelerate the time-to-market for all service customers expanding decentralized production modules and concentrating design and intelligence in one place.

\subsection{Chapter Conclusion}

On this chapter it was presented the product-service architecture (PSA) as a proposition to support the transformation of the production process into productservice offers.

In order to reach a better value co-creation in the service delivery, prediction and monitoring for PSA, it was proposed a modification on the PSA Service Design Discipline introducing intentional elements, reaching an Intentional approach to PSA Service Design Discipline.

The fundamental changes proposed on the previous PSA service design discipline were focus on the Intentional Identification Phase in order to include intentional modeling techniques represented by $\mathrm{i}^{*}$ and KAOS GORE modeling methods.

The Intentional PSA Service Design Discipline was applied on two different contexts, an reference model and a real modeling context using a industrial and manufacturing context.

On the next chapter we are going to analyze the results of the Intentional 
PSA Service Design Discipline as a whole proposition for the Design of Service Systems. 


\section{RESULTS}

The architecture PSA (product-service architecture) in an ongoing research that congregates several contributions from different researchers in Service Design Group at Design Lab in Escola Politecnica da USP.

However, a framework structure guided by a design discipline that encompass the whole view can be extremely powerful to support the creation of the next generation of service system, specially supporting service manufacturing ones.

We presented on this work a proposition to support PSA architecture modeling and design that could be applied to new manufacturing approaches: the Intentional PSA Service Design Discipline.

We are going to analyze its contributions and results on two perspectives: specific and general. As specific results we will see (i) contributions of the proposed discipline in terms of Identification phase, and (ii) the impacts of the introduction of an intentional approach in PSA. General results analysis will be explored by comparative impacts of our proposed discipline: (i) in terms of Service Design Engineering and (ii) in terms of the Service Life-cycle reference. 


\subsection{Specific Results}

\subsubsection{Identification phase}

A central and specific contribution of the Intentional PSA Service Design Discipline, concerning its previous Design Discipline, is the proposed approach for Identification phase.

The precussor of PSA Design Discipline, proposed by, on a pioneer work where Service Design were represent by a primary structure that inspired current PSA (OLIVEIRA; SILVA, 2015; DUTRA; OLIVEIRA; SILVA, 2013).

That primary work also assumed that, in terms of design phases, the key issues are concentrated in the early phases. Therefore, the first approach for PSA design is concentrated on Requirement Engineering stage, although it did not address the problem of the system-as-is modeling and the definition of a more precise Identification phase.

Therefore, besides the introduction of GORE methods, specially i* model, we will propose a consistent modeling approach for the system-as-is, and will include in the Intentional PSA Service Design Discipline a consistent Identification Phase.

Therefore, the specific contribution is bomposed by: (i) a consistent systemto-be derivation process from system-as-is, (ii) a definition of the Expectation element as a central element for value satisfaction, (iii) a preliminary projection method for the identification of expectations from intentionalities and situations, (iv) a service collapse strategy from a viewpoint satisfaction optimization perspective, and (v) a transference strategy from the final set of identified services to goal and softgoals elements.

Following, we analyze each one of the listed specific contribution:

1. System-as-is to System-to-be: Even if the first PSA Design Discipline in- 
herited SOMF's attributes strategy to generate services and Tropos' design method presents a modeling evolution from system-as-is to system-to-be, both have not consistent and logical steps in terms of service identification and collapsing. The Identification phase, though its expectation and service component model, presents consistent and logical steps evolving from system-as-is' intentions to system-to-be's goals and softgoals.

2. Expectation element: The introduction of the expectation element on PSA brought a connection between the intention elements, presented on stakeholder's model, and services' goals and softgoals design element. In fact, the value perception of a service is more related to the satisfaction of a expectation of a stakeholder concerning a specified service, than to its intention (a collection of element with a more broad meaning). This fact have impacts, not just on the design of the value proposition, but can also be a seminar contribution to the PSA value co-creation satisfaction module, to be addressed on a future work.

3. Projection method for expectations' identification: We define expectation as intentions projected over an space of opportunity (collection of situations that create an space for a new service system). The proposed Identification phase specify a heuristic added to an linguistic method inspired on ERi*c's eliciting method. Using the modal verbs SHOULD BE, MAY BE and COULD BE with the previous heuristics, that explore needs and opportunities from intentions, we propose a consistent expectation's identification method for the Identification phase of the Intentional PSA Service Design Discipline.

4. Service collapse strategy: An initial viewpoint collapsing algorithm was proposed by Oliveira (OLIVEIRA; SILVA, 2015) on his primary contribution to PSA's first Design Discipline. Its aim is to collapse the generated set 
of services in order to find the minimum uncoupled set that reaches the maximum of viewpoint expectations. The collapsing strategy proposed on our Identification phase takes a step further than the initial PSA Design Discipline as it proposes an optimization criteria reaching different collapsing outputs. The designer can choose for an collapsing strategy in order to satisfy the maximum of expectation for each single viewpoint or an global strategy that satisfy the maximum of expectations for the whole system.

5. Identified services transference strategy:In terms of a transference strategy, the proposed Identification phase presents a consistent step from conceptual collapsed services to goals and softgoals to a KAOS initial system-to-be modeling phase. As the complete process is traceable, the system-to-be model starts to be modeled by connecting stakeholders, it expectations directly to goals and softgoals elements on a system.

\subsubsection{Intentional approach for PSA}

The second specific contribution of the Intentional PSA Service Design Discipline, concerning it previous Design Discipline, is the addition of the intentional approach.

The importance of this improvement arises from the essence of the Service System's definitions, where value co-creation is a central characteristic.

In fact, the intense customer participation on service systems and the different perception of value (related to each individual cognition process) points for a design process with greater cognition model for the stakeholders. Our hypothesis is that agent oriented approaches could fit better than object-oriented modeling approaches to elicit, model and monitor value co-creation on service systems.

Therefore, the proposed discipline enriched the PSA Service Design Disci- 
pline using a Goal-Oriented Requirement Engineer (GORE) modeling approach. The intentional model is supported by iStar $\left(i^{*}\right)$ approach, representing a multistakeholder model, their intentions and dependencies.

The specific contribution of the introduction of Intentionality on PSA are: (i) a first and consistent definition model for the system-as-is, (ii) the Eri*c method is a satisfactory for the PSA Design Discipline system-as-is elicitation phase PSA, (iii) $i^{*}$ carries already several methods also for modeling and analysis phase (system-as-is), and (iv) some researchers on $i^{*}$ are investigation satisfactions measurement algorithms that could be adapted for the value co-creation module of PSA.

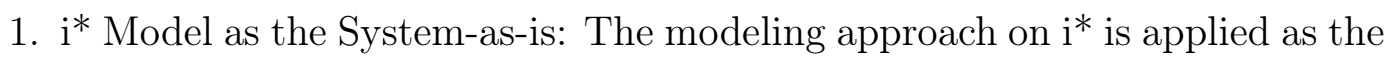
basis for system-as-is model. It is a multi-stakeholder modeling approach that represent their intentions and dependencies. As the first version of PSA approach did not modeled the system-as-is, modeling directly, from elicitation, the requirements for the system-to-be, the introduction of $i^{*}$ modeling approach brought a important modeling improvement. In terms of system-as-is, $i^{*}$ do not reach all modeling needs, representing poorly the context and the domain. To overcome those modeling needs, system-as-is will have to include Knowledge Engineering techniques. To be addressed on a future work.

2. Elicitation through Eri*c: The $\mathrm{ERi}^{*} \mathrm{c}$ method, presented by Oliveira (OLIVEIRA; LEITE, 2011), elicit the system-as-is through interviews and languages transformation mechanisms. Interviews registries pass through a classification on languages structure using passive form tenses, in the search of "why's". It reaches a first system-as-is organized on actors, tasks, goals, softgoals and resources. The method satisfy an elicitation phase for $i^{*}$ models and inspired the expectation projection method used on the iden- 
tification phase.

3. Modeling and analysis phases for System-as-is: In fact, to reach a stable system-as-is model, there are some inherited Modeling and Analysis approaches from i*. Since the basics SD and SR modeling and analysis techniques (ERIC, 2011) until more sophisticated process as proposed by Tropos methodology (BRESCIANI et al., 2004). Therefore, Modeling and Analysis phases for the PSA Service Design Discipline are well placed.

4. Satisfaction measurement algorithms: The introduction of $i^{*}$ approach also promote a possibility of adaptation of some satisfaction measurement algorithms to the PSA value co-creation satisfaction module (HORKOFF; YU, 2012). In terms of architecture, a design output of the Intentional PSA Service Design Discipline is a intentional model of the stakeholders looking forward the feed of the value co-creation satisfaction module that gather real time data from stakeholder and, based on its models, predict stakeholder's expectation. The possibility of using that sort of algorithm is a very strong result from the introduction of the intentional element, because, in terms of service system, value co-creation is one of the most important characteristics.

\subsection{General Results}

\subsubsection{Intentional PSA on Service Engineering}

In order to have a comparative analysis, we expand the table used to compare Service Engineering approaches according to a list o reference attributes, including the Intentional PSA Service Design Discipline (referenced as iPSA on the table) (see table 6).

In terms of Service Design Practical Support, the iPSA satisfy the Design 
Table 6: Attributes for a Reference Services Engineering Design vs Service Engineering Design Approaches

\begin{tabular}{|c|c|c|c|}
\hline \multirow[t]{2}{*}{ Attributes } & \multicolumn{3}{|c|}{ Service Engineering Design Approaches } \\
\hline & SOMF SoftDiss & Tropos & iPSA \\
\hline \multicolumn{4}{|c|}{ Service Designing Practical Support } \\
\hline Design Discipline & $\mathrm{X}$ & $\mathrm{X}$ & $\mathrm{X}$ \\
\hline Framework/Architecture & $\mathrm{e} X$ & $\mathrm{X}$ & $\mathrm{X}$ \\
\hline Design Tool & $(\mathrm{X})$ & $\mathrm{X}$ & $(\mathrm{X})$ \\
\hline \multicolumn{4}{|c|}{ Design Engineering Variables } \\
\hline Traceability & $(\mathrm{X})$ & $\mathrm{X}$ & $\mathrm{X}$ \\
\hline Model-Driven & $\mathrm{X}$ & $\mathrm{X}$ & $\mathrm{X}$ \\
\hline \multicolumn{4}{|c|}{ Service Engineering Design Characteristics } \\
\hline Eliciting & $(\mathrm{X})$ & $(\mathrm{X})$ & $\mathrm{X}$ \\
\hline Modeling & $(\mathrm{X})$ & $\mathrm{X}$ & $\mathrm{X}$ \\
\hline Analysis & $(\mathrm{X})$ & $\mathrm{X}$ & $\mathrm{X}$ \\
\hline Verification & $(\mathrm{X})$ & $(\mathrm{X})$ & $(\mathrm{X})$ \\
\hline System-as-is/to-be & $(\mathrm{X})$ & $\mathrm{X}$ & $\mathrm{X}$ \\
\hline
\end{tabular}

Discipline and Frameworks/Architecture attribute. However, as it inherit some SoftDiss multiple design platforms, specially for the late phases of the design, it do not satisfy completely the attribute Design Tool.

On the other hand, for Design Engineering Variables, iPSA satisfy both, tracebility and Model-Driven. The first due to a consistent process of designing added to TAOM4E and EA Design Tools that support traceability through the process of design. The former, is resulted from a Design discipline and a Service Life-cycle that requires clear separation between models and a modeling process that seeks stabilization before moving forward.

At least, for Service Engineering Design Characteristics, iPSA did not presented a clear and consistent approach for the verification phase. In contrast, the Eri*c method considered as eliciting phase represent a satisfaction for this attribute.

Therefore, in terms of Service Engineering, in general, there were some improvements from the first PSA Service Design Discipline (developed from Soft- 
Table 7: Reference Services and Service Life-cycle characteristics vs Service Design Approach fields

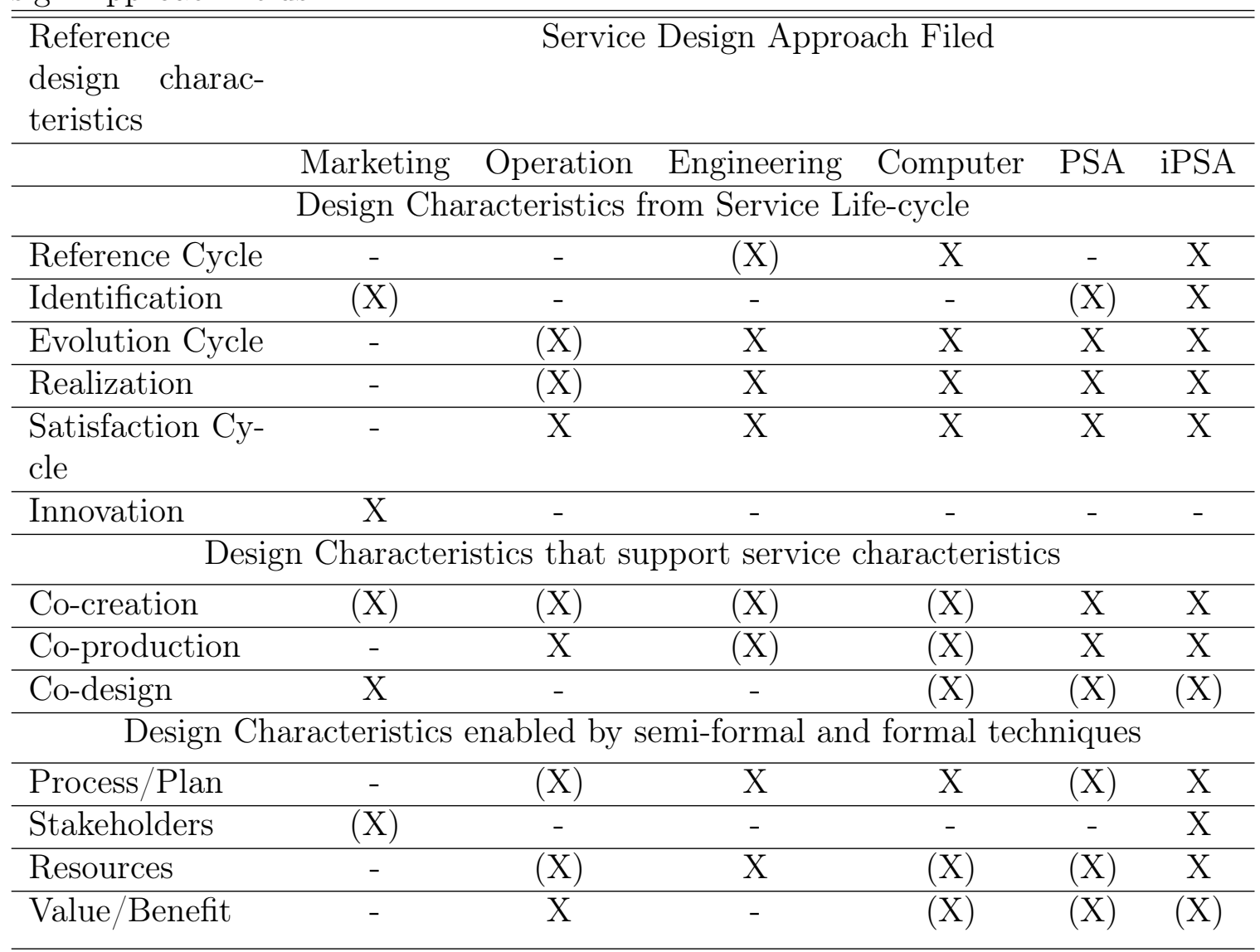

Diss' framework), due specially to some GORE/Tropos approaches influences.

\subsubsection{Intentional PSA on Service Life-cycle}

Using a similar general analysis approach, we expanded the Service Lifecycle comparative table including the Intentional PSA Service Design Discipline (referenced as iPSA on the table)(see table 7).

In terms of that comparative analysis, we are going to include the whole idea of PSA, even if is an ongoing research with promising results.

The iPSA, in terms of the Life-cycle evolved from Engineering and Computer Design approaches improving specially identification phase. The innovation phase must be investigated in future works. 
For the design characteristics, iPSA, due to its architecture, has strong guidelines to concrete application and measurement of the value co-creation and coproduction strategies. However, co-design was not explicitly treated on this work, requiring better deepening on future works.

At least, the fact that iPSA merged Engineering and Computer Sciences concepts and proposals it kept Process/Plan and Resources modeling and execution characteristics, however, in terms of stakeholder modeling, the introduction of Intentionality through system-as-is created a new satisfaction improvement, validated by the representer of the company of the case study. For the Value/Benefit characteristics it is not completely satisfied as PSA value co-creation satisfaction module needs a more clear and concrete proposition. This must be investigated on a future work. 


\section{CONCLUSION AND FUTURE WORK}

In fact, Service Science field have been evolving fast since last decade. The current involvement of academics and practitioner from several different backgrounds transformed the previous specific Marketing academic field on a important scientific and industrial endeavor.

It has great challenges concerning to the consolidation of the service theories, laws, and principles to be applied in practice. In other words, consolidate approaches that can effectively manage and control the behavior and effects of the service systems to its stakeholder.

Service Engineering researchers are studying the impact of services in production advancing manufacture industry to hybrid outputs as the concept of product-service system (PSS), mixing again products and services.

To support the transformation of production to a service-oriented offers we propose the use of a design discipline using the product-service architecture (PSA). The PSA is an approach that combines several design methods available to information systems with other tools to design plans and schedule. A design discipline using PSA can provide a mix of product-service artifact - that can be composed in a planning/scheduling process to achieve new results and more sophisticated artifacts.

Our theoretical conceptual proposal aimed practical incursions to demonstrated improvements of the modeling process. Therefore, what we wanted to 
demonstrate is that the steps of the discipline gathered, aligned to a framework improves the quality of the design process.

However it is not possible to formalize it completely since there is no formal definition of the elements (even for services), therefore it can be turned to a formal method.

\subsection{Improving the design capability of PSA}

The objective of this work was to implement a intentional approach on PSA, proposing a Intentional Service Design Discipline to the architecture.

The results shows that the intentional approach in PSA improved its design capability and it overall coherence with respect to the definitions of service systems.

The comparative analysis with others Service Engineering approaches, including the ancient version of PSA design discipline, showed that there were several improvements of the whole Service Life-cycle, seeking for completeness and reaching more service design characteristics than the others approaches.

\subsection{Increasing the capture of value co-creation on PSA}

As a specific objective, this work intended an increase of the capture of value co-creation variables in the Product-Service Architecture, by including a goaloriented modeling techniques, especially focusing on modeling agents' intentions.

The results pointed to better connections between service's goals and stakeholder's expectations, which means a stronger correlation to accompany value co-creation.

Therefore, Goal-Oriented Requirement Engineer (GORE) modeling approach 
enriched the PSA Service Design Discipline. The intentional model, supported by iStar $\left(i^{*}\right)$ approach, represent a multi-stakeholder model, their intentions and dependencies, that are matched on expectations that provide the link to a systemto-be modeling.

On the satisfaction cycle, of the whole life-cycle, those relationships can be traceable to allow a constant surveillance of value creation during service delivery.

\subsection{Developing a consistent process of deriving system- to-be form the system-as-is on PSA}

As a second specific objective, this work intended to develop a consistent process of deriving a system-to-be from a system-as-is so that it also fills the gap of a non-existent system-as-is in the current version of the Product-Service Architecture.

The results showed a more consistent discipline presented in the early stages of the PSA design life-cycle.

The inclusion of the Identification Phase and its sub-steps, allows a discipline formed by a set of rules, involving steps and tools, to achieve a proposed goal.

\subsection{Future Work}

PSA architecture is still in development, specially in terms of its modules and service manufacturing integration, however a framework aggregation guided by the proposed design discipline that encompass the whole view is already powerful to support the creation of the next service and service manufacturing systems.

As future works we see mainly:

- The development of specific steps for the Innovation transition phase, from 
the Service Life-cycle. The Marketing field present some tools and techniques to grab new opportunities, however, there is some investigations to be made before achieve a formulation of an innovation transition phase.

- A structure to propose and evaluate co-design characteristics, defining where, when and how this characteristic manifest during the whole service life-cycle, investigating its connections with elicitation, validation and verification phases.

- The inclusion of Knowledge Engineering Techniques on the Service Design Discipline in order to improve elicitation and achieve a more consistent system-as-is model.

- The definition and implementation of the value co-creation satisfaction module on PSA. In fact, the value perception of a service is related to the satisfaction of a expectation of a stakeholder concerning a specified service. Defining criteria and developing the internal satisfaction logics will have important impacts on the overall result of PSA.

- The implementation the others PSA Modules, especially workflow and service planner module based on Petri Net and D-Lab proposals approaches.

- The implementation of an integrated modeling platform, supporting the Intention-based service design discipline for the PSA. 


\section{REFERENCIAS}

ALTER, S. Service system innovation. Information technology in the service economy: Challenges and possibilities for the 21st century, v. 267, p. 61-80, 2008. 2

. A Unified, Operational View of Service, Service Systems, and Service Science. INFORMS Annual Meeting, p. 1-17, 2014. 2.1.2, 2.1.2, 2

ANDRIKOPOULOS, V. Separate design knowledge models for software engineering and service based computing. [S.l.], 2009. v. 2. 2.2 .2

AURICH, J. C.; MANNWEILER, C.; SCHWEITZER, E. How to design and offer services successfully. CIRP Journal of Manufacturing Science and Technology, CIRP, v. 2, n. 3, p. 136-143, 2010. ISSN 17555817. Disponível em: $<$ http://dx.doi.org/10.1016/j.cirpj.2010.03.002>. (document), 2.2.1, 2.2.3.3

BAINES, T. Exploring Service Innovation and the Servitization of the Manufacturing Firm. Research-Technology Management, v. 58, n. 5, p. 9-11, 2015. 2.2 .1

BARDHAN, I. R. et al. An Interdisciplinary Perspective on IT Services Management and Service Science. Journal of Management Information Systems, v. 26, n. 4, p. 13-64, apr 2010. ISSN 0742-1222. Disponível em: $<$ http:/ / mesharpe.metapress.com/openurl.asp?genre=article $\{\&\}$ id $=$ doi: 10.2753/MIS0742-1222260>. 2.2.1

BELL, M. Service-Oriented Modeling: Service Analysis, Design, and Architecture. 1st ed.. ed. New Jersey: John Wiley, 2008. 2.3.1

BITNER, M. J.; OSTROM, A. L.; MORGAN, F. N. Service Blueprinting: a practical technique for service innovation. California Management Review, v. 50, n. 3, p. 66-95, 2008. ISSN 00081256. Disponível em: <http://search.ebscohost. com/login. asp ? direct $=\operatorname{true}\{\&\} \mathrm{db}=\mathrm{bth}\{\&\} \mathrm{AN}=32129010\{\&\}$ site $=\mathrm{e}>\mathbf{2} .2 .1$, 2.2.3.2

BLANCHET, M. et al. Industry 4.0 The new industrial revolution How Europe will succeed. [S.l.], 2014. 1 - 24 p. 2.4 .1

BLOMKVIST, J.; HOLMLID, S. Service Design Research: Yesterday, Today and Tomorrow. This is Service Design Thinking: Basics - Tools - Cases, v. 1, p. 308-315, 2010. 2.2.3.1

BRESCIANI, P. et al. Tropos: An Agent-Oriented Software Development Methodology. Autonomous Agents and Multi-Agent Systems, v. 8, 
n. 3, p. 203-236, may 2004. ISSN 1387-2532. Disponível em: < http:

//link.springer.com/10.1023/B:AGNT.0000018806.20944.ef>. 3

BROWN, S. W.; FISK, R. P.; BITNER, M. J. The Development and Emergence of Services Marketing Thought. International Journal of Service Industry Management, v. 5, n. 1, p. 21-48, 1994. ISSN 0956-4233. 2.2.1, 2.2.3.2

CAVALIERI, S.; PEZZOTTA, G. Product-service systems engineering: State of the art and research challenges. Computers in Industry, Elsevier B.V., v. 63, n. 4, p. 278-288, 2012. ISSN 01663615. Disponível em:

<http://dx.doi.org/10.1016/j.compind.2012.02.006>. (document), 2.2.1, 2.2.3.3

CHASE, R. B.; APTE, U. M. A history of research in service operations: What's the big idea? Journal of Operations Management, v. 25, n. 2, p. 375-386, 2007. ISSN 02726963. 2.2.1, 2.2.3.2

CHUNG, L. et al. Non-functional requirements in software engineering. [S.l.]: Springer Science \& Business Media, 2012. 2.3.0.1

DEMARCO, T. Structured analysis and system specification. [S.l.]: Springer Berlin Heidelberg, 2002. 529-560 p. 2.3.0.1

DUTRA, D.; OLIVEIRA, V.; SILVA, J. R. A Service-oriented Approach to Technology Based Industry. In: INDIN IEEE Congress 2014. Porto Alegre, Brazil: [s.n.], 2014. 1, 2.1.2

DUTRA, D.; OLIVEIRA, V. C.; SILVA, J. R. Manufacturing as Service: the challenge of Intelligent Manufacturing. In: 11th IFAC Workshop on Intelligent Manufacturing Systems (IMS13). Sao Paulo, SP, Brasil: [s.n.], 2013. p. 7. 1, $2.1 .2,3.2,3.2,4.1 .1$

DUTRA, D.; SILVA, J. R. From smart products to product-service systems: a Service Engineering perspective from the Industry 4.0. In: Proceedings of XXI Congresso Brasileiro de AutomÃ jtica. Vitoria, Brazil: [s.n.], 2017. In press. 2.4.1 . Product-Service Architecture (PSA): toward a Service Engineering perspective in Industry 4.0. In: Proceedings of 12th IFAC Workshop on Intelligent Manufacturing Systems (IMS 2016). Austin, Texas: [s.n.], 2017. In press. 2.4.1, 3.1, 3.1

EDMAN, K. W. Service Design - a conceptualization of an emerging practice. University of Gothemburg, 2011. 170 p. ISBN 9789197847773. Disponível em: $<$ http://hdl.handle.net/2077/26679>. 2.2.1, 2.2.3.1

ERIC, S. K. Social Modeling for Requirements Engineering. Cambridge, Massachusetts: MIT Press, 2011. 752 p. ISBN 978-0-2622-4055-0. 2.3.0.1, 3

ERL, T. Soa: principles of service design. [S.l.]: Upper Saddle River: Prentice Hall, 2008. 2.2.1 
ERNST, N. A. et al. An Overview of Requirements Evolution. In: Evolving Software Systems. [S.1.]: Springer-Verlag Berlin Heidelberg, 2014. p. 3-32. ISBN 978-3-642-45397-7. 2.3.0.1

EVANS, P. C.; ANNUNZIATA, M. Industrial Internet: Pushing the Boundaries of Minds and Machines. General Electric, p. 37, 2012. 2.4.1

FISK, R. P.; BROWN, S. W.; BITNER, M. J. Tracking the evolution of the services marketing literature. Journal of Retailing, v. 69, n. 1, p. 61-103, 1993. ISSN 00224359. 2.1.1

Fitzsimmons, J. Fitzsimmons, M. Service management: Operations, strategy, information technology. [S.1.]: McGraw-Hill Higher Education, 2013. 1

FOYO, P. del. GHENeSys: Uma Rede Estendida Orientada a Objetos para Projeto de Sistemas Discretos. Tese (Doutorado) — Universidade de São Paulo, 2001. 3.2

GOLDSTEIN, S. M. et al. The service concept: The missing link in service design research? Journal of Operations Management, v. 20, n. 2, p. 121-134, 2002. ISSN 02726963. 2.2.1, 2.2.3.2

GREENSPAN, S.; BORGIDA, A.; MYLOPOUlOS, J. A Requirements Modeling Language and Its Logic. Information Systems, II, n. I, p. 9-23, 1986. Disponível em: <http://www.sciencedirect.com/science/article/pii/0306437986900207>. 2.3.0.1

GRONROOS, C. Value co-creation in service logic: A critical analysis. Marketing Theory, v. 11, n. 3, p. 279-301, 2011. ISSN 1470-5931.

Disponível em: <http://www.scopus.com/inward/record.url?eid=2-s2. $0-80053497835\{\&\}$ partnerID $=$ tZOtx $>1$

GROVE, S. J.; FISK, R. P.; JOHN, J. The future of services marketing: forecasts from ten services experts. Journal of Services Marketing, v. 17, n. 2, p. 107-121, 2003. ISSN 0887-6045. 2.1.1

HALSKOV, K.; HANSEN, N. B. The diversity of participatory design research practice at PDC 2002-2012. International Journal of Human Computer Studies, Elsevier, v. 74, p. 81-92, 2015. ISSN 10959300. Disponível em: $<$ http://dx.doi.org/10.1016/j.ijhcs.2014.09.003>. 2.2.3.1

HERMANN, M.; PENTEK, T.; OTTO, B. Design Principles for Industrie 4.0 Scenarios: A Literature Review. 2015. 2.4.1

HESKETT, J. L. et al. Putting the service-profit chain to work. Harvard Business Review, v. 86, n. 7-8, 2008. ISSN 00178012. 2.2.3.2

HORKOFF, J.; YU, E. Comparison and evaluation of goal-oriented satisfaction analysis techniques. Requirements Engineering, v. 18, n. 3, p. 199-222, jan 2012. ISSN 0947-3602. Disponível em: <http://link.springer.com/10.1007/ s00766-011-0143-y>. 2.3.1, 3.3, 4 
HUANG, K.-h. et al. A Model-Driven Service Design Toolkit : From Co-Design to Implementation. The 5th International Congress of International Association of Societies of Design Research, 2013. 2

HURWITZ, J. et al. Service Oriented Architecture for Dummies. [S.l.]: John Wiley \& Sons, 2007. 76 p. ISBN 9780470525494. 2.2.1, 2.2.3.4

IBM, I. and. Succeeding through service innovation: a service perspective for education, research, business and government. [S.l.], 2008. 2.1.1, 1, 2, 2.2.1, 2.2.3.4

JACKSON, M. System Development. [S.l.]: Prentice Hall International, 1983. ISBN 0138803285. 2.3.0.1

JARKE, M. et al. Theories underlying requirements engineering: an overview of NATURE at Genesis. [1993] Proceedings of the IEEE International Symposium on Requirements Engineering, v. 6353, n. March 1988, p. 948-956, 1993. 2.2.2

JURETA, I. J. et al. The Requirements Problem for Adaptive Systems. ACM Transactions on Management Information System, v. 5, n. 17, 2014. ISSN 2158656X. Disponível em: <http://dx.doi.org/10.1145/2629376>. 2.3.0.1

KEITH, M.; DEMIRKAN, H.; GOUL, M. Service-Oriented Methodology for Systems Development. Journal of Management Information Systems, v. 30, n. 1, p. 227-260, 2013. ISSN 0742-1222. Disponível em: < http: //www.tandfonline.com/doi/full/10.2753/MIS0742-1222300107>. 2.2.3.4

KENT, S. Model driven engineering. In: Integrated Formal Methods. Verlag Berlin Heidelberg: Springer, 2002. p. 286-298. Disponível em: $<$ http://www.springerlink.com/index/9VUQB4HP8FYG2ADV.pdf > 2.3 .2

KONTONYA, G.; SOMMERVILLE, I. Requirements engineering: processes and techniques. [S.l.]: John Wiley \& Sons, Inc., 2002. 2.3.0.1

LAMSWEERDE, A. V. Requirements Engineering: From System Goals to UML Models to Software Specifications. Glasgow: Wiley, 2008. ISBN 978-0-470-01270-3. 2.3, 2.3.0.1

LAMSWEERDE, A. van. Goal-oriented requirements engineering: a guided tour. Proceedings Fifth IEEE International Symposium on Requirements Engineering, p. 249-262, 2001. ISSN 1090-705X. Disponível em: < http: / /ieeexplore.ieee.org/lpdocs/epic03/wrapper.htm?arnumber $=948567>$. 2.3.0.1

LIU, L.; YU, E. Designing information systems in social context: a goal and scenario modelling approach. Information Systems, v. 29, n. 2, p. 187-203, apr 2004. ISSN 03064379. Disponível em: < http: //linkinghub.elsevier.com/retrieve/pii/S0306437903000528>. 2.3.0.1

LUSCH, R.; VARGO, S.; WESSELS, G. Towards a conceptual foundation for service science: Contributions from service-dominant logic. IBM Systems Journal, p. 1-9, 2008. 1, 1 
LUSCH, R. F.; VARGO, S. L. Service-dominant logic: reactions, reflections and refinements. Marketing Theory, v. 6, n. 3, p. 281-288, 2006. ISSN 1470-5931. 2

LUSCH, R. F.; VARGO, S. L.; TANNIRU, M. Service, value networks and learning. Journal of the Academy of Marketing Science, v. 38, n. 1, p. 19-31, 2010. ISSN 00920703. 2

MAGER, B. Service design as an emerging field. Designing services with innovative methods, p. 28-42, 2009. 2.2.1, 2.2.3.1

. What is Service Design? Touchpoint: The Journal of Service Design,

v. 1, n. 1, p. 1-61, 2009. 2.2.3.1

MAGLIO, P. et al. Service systems, service scientists, SSME, and innovation. Communications of the ACM, ACM, v. 49, n. 7, p. 85, 2006. (document), 2.1.1

MAGLIO, P. P. Toward a Science of Service Systems. 2009. Presentation at IBM Almaden Research Center p. 1

MAGLIO, P. P. et al. The service system is the basic abstraction of service science. Information Systems and e-Business Management, v. 7, n. 4, p. 395-406, 2009. ISSN 1617-9846. 1

MEIER, H.; ROY, R.; SELIGER, G. Industrial Product-Service systems-IPS2. CIRP Annals - Manufacturing Technology, v. 59, n. 2, p. 607-627, 2010. ISSN 00078506. 2.2.3.3

MOHAMMADI, M.; MUKHTAR, M. A Review of SOA Modeling Approaches for Enterprise Information Systems. Procedia Technology, Elsevier B.V., v. 11, n. Iceei, p. 794-800, 2013. ISSN 22120173. Disponível em: <http://www.sciencedirect.com/science/article/pii/S2212017313004143>. 2.2.3.4

MORITZ, S. Service Design - Practical Access to an Evolving Field. Köln International School of Design., 2005. ISSN 1530-5627. ISBN 1556-3669 (Electronic) 1530-5627 (Linking). Disponível em: <http: //www.pubmedcentral.nih.gov/articlerender.fcgi?artid $=3212890\{\&\}$ tool $=$ pmcentrez $\{\&\}$ rendertype=abstract $\$$ delimiter"026E30F \$nhttp://www. liebertonline.com/doi/abs/10.1089/tmj.201>. 2.2.3.1

MOUSSA, S.; TOUZANI, M. A literature review of service research since 1993. Journal of Service Science, v. 2, n. 2, p. 173-212, dec 2010. ISSN 2005-3274. (document), 2.1.1, 2.2.1, 2.2.3.4

MYLOPOULOS, J. et al. Telos: Representing knowledge about Information systems. ACM Transactions on Information System, v. 8, n. 4, p. 325-362, 1990. ISSN 10468188. 2.3.0.1

NOF, S. Y. et al. Revolutionizing Collaboration through e-Work, e-Business, and e-Service. 2nd. ed. New York, New York, USA: Springer Heidelberg New York Dordrencht London, 2015. 438 p. ISBN 9783662457764. 2.4.1 
NUSEIBEH, B.; EASTERBROOK, S. Requirements Engineering: A Roadmap. Proceedings of the Conference on the Future of Software Engineering, p. 35-46, 2000. ISSN 00368075. 2.3.0.1

OLIVEIRA, A. D. P. A.; LEITE, J. C. P. Building Intentional Models Using the ERi *c Method. Cadernos do IME-Série Informática, v. 32, p. 46-53, 2011. 3.3, 3.7.1, 2

OLIVEIRA, A. D. P. A.; LEITE, J. C. S. D. P. INTENTIONAL REQUIREMENTS ENGINEERING: A METHOD FOR REQUIREMENTS ELICITATION, MODELING, AND ANALYSIS. Tese (Doutorado) PUC-RIO, 2008. 3.3

OLIVEIRA, V. C. Modelagem e design de sistemas de servico para automacao. 232 p. Tese (Doutorado) - Escola Politecnica da Universidade de Sao Paulo, 2013. 2.3.1, 3.2

OLIVEIRA, V. C. de; SILVA, J. R. A service-oriented framework to the design of information system service. Journal of Service Science Research, v. 7, n. 2, p. 55-96, 2015. 1.2, 3.1, 3.2, 3.2, 4.1.1, 4

(OMG). Object Management Group. 2009. http://www.uml.org/ p. 2.3.0.1, 2.3 .2

OSTROM, A. L. et al. Service Research Priorities in a Rapidly Changing Context. Journal of Service Research, v. 18, n. 2, p. 127-159, 2015. ISSN 1094-6705. Disponível em: <http://www.scopus.com/inward/record.url?eid= 2-s2.0-84927646419 $\{\&\}$ partnerID $=$ tZOtx $>$. 2.1.1, 2

PARASURAMAN, A.; ZEITHAMAL, V. A.; BERRY, L. L. A conceptual model of service quality and its implications for future research. Journal of Marketing, v. 49, n. Fall, p. 41-50, 1985. 2.2.3.2

PATRICIO, L. et al. Multilevel Service Design: From Customer Value Constellation to Service Experience Blueprinting. Journal of Service Research, v. 14, n. 2, p. 180-200, 2011. ISSN 1094-6705. 2.2.1

PINHANEZ, C. Service Systems as Customer-Intensive Systems and its Implications for Service Science and Engineering. In: SPRAGUE, J.; RAHPH, H. (Ed.). Proceedings of the 41st Hawaii International Conference on System Sciences. [S.l.]: IEEE Comput. Soc. Press, 2008. p. 1-10. 1, 2.4

POHL, K.; ULFAT-BUNYADI, N. The Three Dimensions of Requirements Engineering: 20 Years Later. Seminal Contributions to Information Systems Engineering,, p. 81-87, 2013. Disponível em: < http://link.springer.com/10. 1007/978-3-642-36926-1>. 2.3.0.1

QIU, R. G. Service Science: The Foundations of Service Engineering and Management. [S.1.]: John Wiley \& Sons, 2014. 1, 2.1.2, 2.1.2, 2.2.2, 3.1 
RALYTÉ, J.; KHADRAOUI, A.; LÉONARD, M. Designing the Shift from Information Systems to Information Services Systems. Business \& Information Systems Engineering, v. 57, n. 1, p. 37-49, 2015. ISSN 2363-7005. Disponível em: <http://link.springer.com/10.1007/s12599-014-0364-y>. 2.2.1, 2.2.3.4

ROSS, D. T. Structured Analysis (SA): A Language for Communicating Ideas. IEEE Transactions on Software Engineering, SE-3, n. 1, p. 16-34, 1977. ISSN 00985589. 2.3.0.1

SAKAO, T.; HJELM, O. Service As a Means of Communicating User Value and Environmental Benefits in Ecodesign. International Design Conferece - Design 2010, p. 947-954, 2010. 2.2.3.3

SAKAO, T.; MIZUYAMA, H. Understanding of a product/service system design: a holistic approach to support design for remanufacturing. Journal of Remanufacturing, v. 4, n. 1, p. 1-24, 2014. ISSN 2210-4690. 2.2.1, 2.2.3.3

SAKAO, T. et al. Modeling design objects in CAD system for Service/Product Engineering. Computer Aided Design, Elsevier Ltd, v. 41, n. 3, p. 197-213, 2009. ISSN 00104485. Disponível em: <http://dx.doi.org/10.1016/j.cad.2008.06.006>. 2.4

SAMPSON, S. A customer-supplier paradigm for service science. In: DSI Service Science Miniconference. Pittsburgh: [s.n.], 2007. p. 11-16. 2.4

SAMPSON, S. E. A Unified Theory of Service. In: MAGLIO, P. P.; KIELISZEWSKI, C. A.; SPOHRER, J. C. (Ed.). Handbook of Service Science. [S.l.]: Springer Verlag, 2010. p. 117-131. 2.1.2, 1

. Visualizing Service Operations. Journal of Service Research, v. 15, n. 2, p. 182-198, apr 2012. ISSN 1094-6705. (document), 3.7, 3.7.1, 31

SAMPSON, S. E.; FROEHLE, C. Foundations and Implications of a Proposed Unified Services Theory. Handbook of service science, v. 15, n. 2, p. 329-343, 2006. 2.1.2, 2

SASSANELLI, C. et al. Towards a Lean Product Service Systems (PSS) Design: State of the Art, Opportunities and Challenges. Procedia CIRP, Elsevier B.V., v. 30, p. 191-196, 2015. ISSN 22128271. Disponível em: <http://linkinghub.elsevier.com/retrieve/pii/S2212827115003534>. 2.2.3.3

SAWYER, P.; KONTONYA, G. Software Requirements. In: Guide to the Software Engineering Body of Knowledge - SWEBOK. [S.l.: s.n.], 2001. p. 9-34. ISBN 0769510000. 2.3.0.1, 3.6.1

SCHMENNER, R. W. Manufacturing, service, and their integration: some history and theory. International Journal of Operations \& Production Management, v. 29, n. 5, p. 431-443, 2009. ISSN 0144-3577. 2.2.1, 2.2.3.3 
SHIMOMURA, Y.; NEMOTO, Y.; KIMITA, K. State-of-art Product-Service Systems in Japan - The latest Japanese Product-Service Systems developments. Procedia CIRP, Elsevier B.V., v. 16, p. 15-20, 2014. ISSN 22128271. Disponível em: <http://dx.doi.org/10.1016/j.procir.2014.01.003>. 2.2.3.3

SILVA, J. R. New Trends in Manufacturing : Converging to Service and Intelligent Systems. In: IFAC World Congress 2014. Cape Town, South Africa: Elsevier, 2014. (document), 1, 6

SILVA, J. R.; NOF, S. Y. Manufacturing service: From e-work and serviceoriented approach towards a product-service architecture. IFAC Proceedings Volumes (IFAC-PapersOnline), v. 48, n. 3, p. 1628-1633, 2015. ISSN 14746670. (document), 1.1, 2.4.1, 3.1

SPOHRER, J. et al. Steps Toward a Service Systems. IEEE Computer Society, n. January, p. 71-77, 2007. 1

STANICEK, Z. SSME*: Service Systems, Modeling, Execution, Education, Evaluation. [S.1.]: Masaryk University, 2009. 2.1.1, 1, 2

TOMIYAMA, T. Service engineering to intensify service contents in product life cycles. Proceedings Second International Symposium on Environmentally Conscious Design and Inverse Manufacturing, p. 613-618, 2001. Disponível em: $<$ http:/ /ieeexplore.ieee.org/lpdocs/epic03/wrapper.htm?arnumber=992433>. (document), 2.2.1, 2.2.3.3

TUUNANEN, T. A new perspective on requirements elicitation methods. The Journal of Information Technology Theory and Application, v. 5, n. 3, p. 45-72, 2003. 2.3.0.1

VAQUERO, T. S. et al. itSIMPLE 2 . 0 : An Integrated Tool for Designing Planning Domains. Association for the Advancement of Artificial Intelligence, p. 336-343, 2007. 3.1, 3.2

VAQUERO, T. S.; SILVA, J. R. The itSIMPLE tool for Modeling Planning Domains. American association for Artificial Inteligence, 2005. 3.1

VARGO, S. L.; LUSCH, R. F. Evolving to a New Dominant Logic. Journal of Marketing, v. 68, n. January, p. 1-17, 2004. 2.1.1

- Service-dominant logic: what it is, what it is not, what it might be. In: VARGO, S. L.; LUSCH, R. F. (Ed.). The service-dominant logic of marketing: dialog, debate, and directions. Armonk: M.E. Sharpe, 2006. p. 43-56. 1

. Advancing Service Science with Service-Dominant Logic. In: MAGLIO, P.; KIELISZEWSKI, C.; SPOHRER, J. (Ed.). Handbook of service science. [S.l.]: New York, 2010. 1, 1

VOSS, C.; HSUAN, J. Service Science: The Opportunity to Re-think What We Know About Service Design*. Springer Science+Business Media, p. 231-244, 2011. ISSN 17575818. Disponível em: < http://www.springerlink.com/content/ $\mathrm{x} 8164610 \mathrm{~h} 2272776 />\cdot 2.2 .3 .2$ 
WAHLSTER, W. Industry 4.0: From Smart Factories to Smart Products. 2012. 2.4 .1

WANG, J. et al. On a Unified Definition of the Service System: What is its Identity? Systems Journal, IEEE, PP, n. 99, p. 1-6, 2013. 2.1.2, 1

Wetter Edman, K. Exploring Overlaps and Differences in Service Dominant Logic and Design Thinking. First Nordic Conference on Service Design and Service Innovation, p. 1-12, 2009. 2.2.3.1

WETTER-EDMAN, K. et al. Design for Value Co-Creation: Exploring Synergies Between Design for Service and Service Logic. Service Science, v. 6, n. 2, p. 106-121, 2014. ISSN 2164-3962. Disponível em: <http: //pubsonline.informs.org/doi/abs/10.1287/serv.2014.0068>. 2.2.1

YU, E. Agent orientation as a modelling paradigm. Wirtschaftsinformatik, v. 43, n. April, p. 123-132, 2001. 2.3, 2.3.0.1

YU, E.; MYLOPOULOS, J. Why goal-oriented requirements engineering. In: Proceedings of the 4th International Workshop on Requirements Engineering: Foundations of Software Quality. [S.l.: s.n.], 1998. (document), 12, 13, 15

YU, E. S.; MYLOPOULOS, J. Modelling Strategic Relationships for Process Reengineering. Tese (Doutorado), 1995. 3.4

YU, E. S.-k. Towards modelling and reasoning support for early-phase requirements engineering. Proceedings of ISRE '97: 3rd IEEE International Symposium on Requirements Engineering, IEEE Comput. Soc. Press, p. 226-235, 1997. Disponível em: <http://ieeexplore.ieee.org/lpdocs/epic03/ wrapper. htm?arnumber $=566873>$. (document), 2.3.0.1

ZAVE, P.; YEH, R. T. Executable requirements for embedded systems. Proceedings of the 5th international conference on Software engineering, p. 295-304, 1981. ISSN 02705257. 2.3.0.1

ZOMERDIJK, L. G.; VOSS, C. a. Service Design for Experience-Centric Services. Journal of Service Research, v. 13, n. 1, p. 67-82, 2010. ISSN 1094-6705. 2.2.3.2 